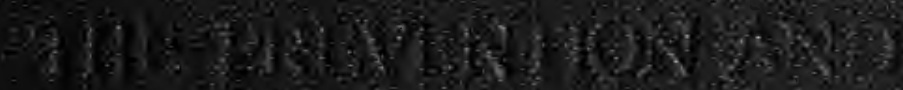

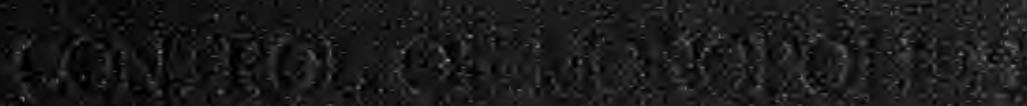

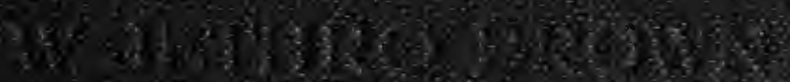


Digitized by the Internet Archive in 2007 with funding from Microsoft Corporation 

THE PREVENTION AND CONTROL OF MONOPOLIES 



\section{THE PREVENTION AND CONTROL OF MONOPOLIES}

BY W! JETHRO BROWN, LL.D., LitT.D.

OF THE MIDDLE TEMPLE, BARRISTER-AT-LAW, SOMETIME MACMAHON STUDENT OF ST. JOHN'S COLLEGE, CAMBRIDGE; AUTHOR OF "THE AUSTINIAY THEORY OF LAW," "THE UNDERLYNG PRINCIPLES OF MODERN LEGISLATION," ETC.

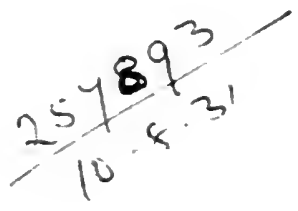

\section{LONDON}

JOHN MURRAY, ALBEMARLE STREET, W.

$$
\text { I } 914
$$


All Rights Reserved 
TO

HIS HONOUR

SIR JOHN GORDON 



\section{PREFACE}

THE many learned contributions, which have been made in recent years on the subject of monopolies, impose upon me the obligation of stating the precise scope and purpose of the present work. I do not propose, save very incidentally, to trace the origin of monopolies, to classify their forms, or to illustrate their powers of exploitation. These things have been done, and effectively done, in a number of well-known treatises. But, at any rate in most of these treatises, the subject of remedies, though of supreme importance from the point of view of the community, has been relegated to concluding chapters. In the present volume, I address myself specifically to the questions within what limits monopolies should be prevented, how the prevention should be effected, and how, where a policy of prevention is undesirable or impracticable, monopolies should be regulated or controlled. I am, moreover, less concerned to state novelties in the way of remedial legislation than to select from among many remedies which are more or less partially reflected in contemporary legislation those which may be regarded as really serviceable, to indicate their 
respective scope and limitations, to outline the administrative machinery necessary to their effectual working, and to show how, by a judicious combination of them, the community can control in the general interest the tendency towards concentrated capitalism. The reader will not need to be informed that the tendency in question, while it may enhance industrial efficiency, threatens to become, if indeed it has not already become, a grave menace to the social order.

The ambitious character of the work which I have tried to perform was enforced upon me by an association with the work of a Royal Commission on the Australian Sugar Industry. By Letters Patent, first issued in IgII, His Honour, Sir John Gordon, the Hon. Albert Hinchcliffe, Messrs. R. M. McCheyne Anderson, M. R. Shannon and $T$. W. Crawford, were appointed to inquire into and report upon the Sugar Industry in Australia, and more particularly in relation to Growers, Manufacturers, Refiners, Workers, Purchasers, Consumers, Costs, Profits, Wages, Prices, the operation of existing Laws, and the nature of any remedial legislation that might be deemed necessary. Under the Chairmanship of Sir John Gordon, the Commission conducted the most searching investigation that has yet been made into any Australian industry. Unfortunately, the Chairman was compelled through ill-health to resign before completing the examination of witnesses. I was appointed to continue his work. For some years I had been a student of the problems which arise in relation to monopolies. But I had little realised the extent of the diff- 
culties which confront investigators called upon to suggest definite solutions in an industry where monopoly control co-existed with public and private ownership, with corporate, co-operative and individualistic production, and with a division of legislative control between Federal and State Parliaments. If the experience was chastening, it was not without its value as an opportunity to test views previously held. I was compelled to formulate anew, to qualify, to correct-happily with the whole-hearted assistance of colleagues well versed in practical affairs. I wish to acknowledge how much I owe to their aid. But I am still more indebted to Sir John Gordon, with whom I had the honour to be associated during the period in which he presided over the investigations of the Commission.

Although I make frequent use of Australian data, and refer at some length to the legislation of the Commonwealth or States, I have kept in view a wider audience than the Australian electorate. While the varying conditions of modern communities involve differences in remedial legislation, the differences so far as the problem of monopoly is concerned more often affect the relative value of different remedies, or the particular means for giving effect to them, than challenge their validity as remedies. Publicity, to quote one example, is a serviceable remedy everywhere, although it may achieve more in one country than in another, and although the instrumentalities through which it operates are necessarily conditioned by local circumstance. Apart from this aspect of the matter, I have felt 
that the very experimental character of much of the Australian legislation gives to it an interest and value, whether as an example or as a warning, for reformers in other countries which are less remarkable for facility of legislation.

W. JETHRO BROWN.

Angust I, I9I4. 


\section{CONTENTS}

\section{CHAPTER I}

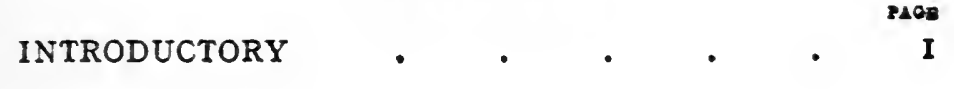

CHAPTER II

SYNDICALISM •

CHAPTER III

THE STATE AND MONOPOLIES • . . 4 I

CHAPTER IV

LIMITATION OF CORPORATE SIZE • • 59

CHAPTER V

PUBLICITY $\quad$ • $\quad$ • $\quad$ • $\quad$ • 70

\section{CHAPTER VI}

LEGISLATIVE REGULATION AND ADMINISTRATIVE SUPERVISION, OF THE CONDITIONS OF COMPETITION 


\section{CHAPTER VII}

THE REGULATION OR CONTROL OF PERSISTENT MONOPOLY • • • • • 97

\section{CHAPTER VIII}

NATIONALISATION $\quad$ - $\quad$ - $\quad$ - $\quad$ - III

CHAPTER IX

PUBLIC CONTROL OF PRICES • • • I25

\section{CHAPTER $\mathrm{X}$}

THE NEW SOUTH WALES GAS ACT, IgI2 - I45

\section{CHAPTER XI}

"NEW PROTECTION" AND PRICE CONTROL AS ILIUSTRATED IN THE AUSTRALIAN SUGAR INDUSTRY • • • • • I $\quad$ I49

\section{CHAPTER XII}

SUMMARY AND CONCLUSION • • • I72

\section{APPENDIX A}

THE QUEENSLAND CANE PKICE BOARDS BILL I84 


\section{SYNOPSIS}

\section{CHAPTER I}

INTRODUCTORY

I. Causes working for concentration of capital . ${ }^{\text {PAOE }}$

II. Meaning of terms : $\quad . \quad$. $\quad$. 3

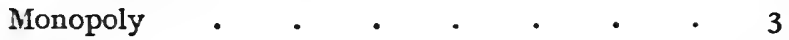

Trust . . . . . . . .

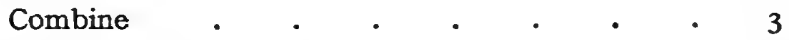

III. Monopolies and the community ${ }^{\cdot}$. . . 4

Nature of the problem . . . . . . 4

Public and private control . $\quad$. $\quad$. 5

\section{CHAPTER II}

\section{SYNDICALISM}

I. Character of the movement a . . . 6

Distinguished from anarchy . . . . 6

Socialism . $\quad . \quad . \quad . \quad . \quad . \quad .7$

The co-operative workshop . . . 7

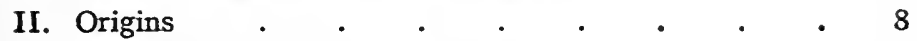

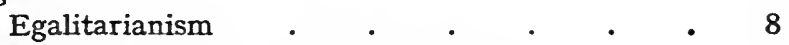

Defects of Parliamentary government . $\quad$. 9

Anomalies of presenteconomic order from the point of view of distributive justice . . . Io

Difficulties of controlling capital save by confiscation . . . . . . . . I3

III. Critical examination of syndicalism . . . . $I_{5}$

I. Its social data $\quad . \quad$. $\quad . \quad$. $\quad . \quad$. 16

Analysis of the "capitalistic class" . . I7

Allegedantagonism between capital and labour 20

Forms of group conflict . . . $\quad 22$ 
2. The syndicalist's remedy PAGS

• $• \cdot{ }^{\circ} 23$

3. The general strike . . . . $\quad 25$

Parliamentary institutions: . . . $\quad 25$

Explanation of their relative failure . . 26

The natural remedy . $\quad . \quad$. $\quad$. 27

Defects of syndicalist's remedy . . . 28

4. Industrial reorganisation as proposed by syndicalism . . . . . . . 30

IV. Underlying truths in syndicalism . . . $\quad 32$

r. Wealth less an individual than a social product 33

2. Claims of private property conditioned by considerations of the social good . . . 34

3. Need for greater distributive justice . . 36

4. Concentrated capitalism and its dangers . 37

5. Monopolisticcapitalism-the need for itscontrol $3^{8}$

6. Co-operative production . . . . 39

\section{CHAPTER III}

\section{THE STATE AND MONOPOLIES}

Policies of monopoly control . . . . . $4^{\mathrm{I}}$

Classification . . . . . . . $\quad$. 42

I. No one policy adequate . . . . . . 43

Variations in milieu . . . . . . 43

Variations in character of different industries . 44

II. Complexity of problem of monopoly control . $\quad 45$

Note re nationalisation, laissez-faire, etc. . . 45

III. Is the maintenance of competitive industry desirable ? $\quad 48$

I. Wastes of competition reducible . . . 48

2. Value of competition in relation to the "fair price" 49

3. Value of competition as a stimulus to production . . . . . . . . 49

4. Summary . . . . . . $\quad$. 50

IV. Is the maintenance of competitive industry practicable? $\quad 52$

Why many trusts are created . . . . 53

Why some trusts survive . $\quad . \quad$. $\quad . \quad 53$

Disadvantages of the big business . $\quad$. 54

The persistent survival of the small business . 55

Conclusion re trusts . $\quad . \quad$. $\quad . \quad 56$

Combines : the experience of the United States . 57 


\section{CHAPTER IV}

\section{THE LIMITATION OF CORPORATE SIZE}

I. The policy explained

PAOS

59

r. Opinions of Mr. Howland, Professor Clark and President Wilson . . . . . 60

2. Peculiarities of American conditions . . 6r

Graft • . . . . . . $6 I$

American enterprise . . . . . 6I

The magnitude of the American market . 62

II. Expediency of policy . $\quad . \quad$. $\quad . \quad$. 62

r. Advantages of large scale business . . 63

2. Are those advantages to be gained in all important industries before monopoly control is gained ? . . . . . . . 64

3. If not, ought we, as between the two alternatives, to prefer competitive industry ? . . 66

III. Practicability of policy . • . . • . 66

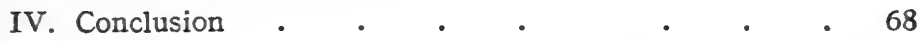

\section{CHAPTER V}

\section{PUBLICITY}

Advantages .

Has the community a right to insist on disclosures of profits ? 7r Machinery . . . . . . . . . 72

Australian Legislation . . . . . . 72

The Canadian Combines Investigation Act . $\quad 74$

Inadequacy of Australian and Canadian legislation . $\quad 75$ Company Law . . . . . . . . .

\section{CHAPTER VI}

THE LEGISLATIVE REGULATION AND ADMINISTRATIVE SUPERVISION OF COMPETITION

I. Introductory

General purposes

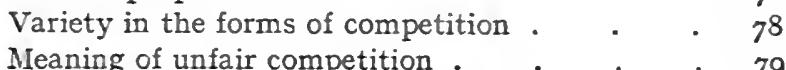

II. Commonwealth Anti-Trust Legislation . . $\quad 80$

Important sections . . . . . . 80

Their general purport . . . . $8 z$ 
III. Critical examination

r. Constitutional limitations . . . . 83

Desiderata in the case of divided control over trusts, etc. . . . . . $\quad .85$

2. Machinery for setting law in motion . $\quad 86$

3. Costs . . . . . . $\quad$. 88

4. Vagueness of definition of unfair competition. 88

? How far a defect . . . . . $\quad$. 89

Need for a commission with administrative and judicial powers . . . . 90

IV. Ancillary legislation necessary. . . . 94

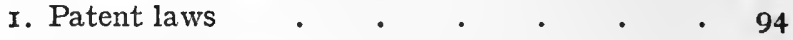

2. High tariffs . . . . . . 95

3. Inter-Stock holdings . . . . . 96

\section{CHAPTER VII}

THE REGULATION OR CONTROL OF PERSISTENT MONOPOLY

I. Limited value of policies previously considered $\quad 97$

Publicity . . . . . . . 97

Legal regulation and administrative supervision of competition, e.g. $\quad$. $\quad$. $\quad$. 98

I. Naturally non-competitive industries . 98

2. Business unit monopoly . . . 99

3. Honourable understandings, etc. . . 99

II. Public competition . . . . . . 105

Difficulties of . $\quad . \quad . \quad . \quad . \quad . \quad$. 106

Relation to nationalisation . . . . 108

III. The limitation of profits to a fixed percentage on capital Iog

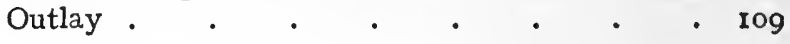

\section{CHAPTER VIII}

\section{NATIONALISATION}

I. Definition . . . . . . . . III

II. Nationalisation of monopolies in relation to the theory of socialism. . . . . . . II2

III. Where nationalisation is prima facie justifiable $\quad \mathbf{I r}_{3}$

I. Transport services . . . . . $\quad$ Ir 


\section{SYNOPSIS}

2. Industries vitally affecting national health, e.g. milk supply • • • • • • • II3

3. Where private ownership threatens depletion of national resources

4. Where public control of prices charged by a monopoly is impracticable.

PAGE

Note.-Special circumstances may tell against, as well as for, nationalisation . . . . . II4

E.g. Australian sugar refining industry . . II4

IV. Disadvantages of public ownership . . . . 116

Suspension of struggle for existence . . . II8

Inefficiency of the Civil Service . . . II9

I. Dismissals . • • • • • II9

2. Difficulties of administrative reform . II

3. Appointments • . • . . 120

V. General conclusion . . . . . . . 123

\section{CHAPTER IX}

\section{THE PUBLIC CONTROL OF PRICES}

I. Is it possible for public authorities to fix prices? . 125

Employees . . . . . . . I27

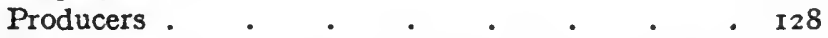

Consumers . . . . . . . . 129

2. On what basis could a public authority determine what

is a reasonable price? . . . . . . r $3 \mathrm{r}$

3. How would a public authority compel observance of its decrees?

4. Has the community a moral right to dictate prices to a private concern?

5. Would not price control impair efficiency ? . . I 35

6. Would it not tend to entrench a parasitic capitalism ? I I37

7. Would it not be a step to socialism ? . . . 138

8. Has it not proved a failure in the past ? . . . I 40

9. Is it not condemned by political economists? . . I4I

Note.-Limits within which price control is recommended $\mathrm{I}_{43}$ 



\section{THE PREVENTION AND CONTROL OF MONOPOLIES}

\section{CHAPTER I}

INTRODUCTORY

\section{Causes Working for Concentration of CAPITAL}

For more than a century, certain causes have operated, with an ever accelerating power, to effect a revolution in the economic structure of society. The primary cause has been progress in man's control over nature. The triumphant achievements of steam and electricity, in making the large business possible, tend in many industries to make the small business unprofitable. They add wings to the human spirit: they multiply indefinitely the possibilities of collective human action. The mediæval merchant, in his control over men and the forces of nature, was far removed from the savage; yet he was but a child in comparison with the modern financial magnate, with his disciplined army of subordinates, his factories, his telephones, his post-bag, and his little tape ticking out from moment to moment the reports of the world's markets.

Secondary and associated causes have strengthened the movement towards concentrated capitalism. (I) Increased opportunities of making 
wealth, and the multiplication of the forms of spending wealth, have stimulated "men's imagination or appealed to their greed. (2) The laws which confer privileges and immunities upon the body corporate have afforded a means and an inducement to associated activity. (3) The increasing severity of the struggle for survival in the business world has impelled rival concerns to endeavour to substitute co-operation or combination for competition. (4) The organisation of labour, if in a part a result, has also been a cause, of the movement towards the concentration of industrial capital. (5) In many countries, high import duties, by eliminating or weakening the effective power of foreign competition, has fostered the formation of the domestic trust or combine. Although the existence of trusts in free-trade countries discounts the sweeping generalisation that "The mother of all trusts is the tariff," there can be no doubt of the truth of Professor Clark's comment, "The honest manufacturer, whom for our good we must protect, is crushed under a high duty as he would not be under a low one." 1

In the foregoing remarks, I have made no distinction between the tendency towards monopoly and the tendency towards concentration. The tendencies are closely interrelated. Facilities for concentration have widened the field within which monopoly is possible; and the advantages of monopoly have often been the motive for concentration. In the present work, I am concerned with monopoly, and the more important

1 "The Problem of Monopoly," First Edition, p. 59. 
means by which it may be prevented, regulated or controlled.

\section{Meaning of Monopoly, Trust, Combine}

In strict accuracy, a monopoly implies an exclusive control over the supply of some service or commodity. In ordinary usage, the term has a more flexible meaning. It exists where, as a result of agreement, consolidation or dominant control, there is an absolute or virtual abeyance of competition as a factor in the determination of the price of a commodity or service. I use the term in this extended sense. I exclude from competition, the "collateral competition" of a substitutable commodity or service. Again, I do not insist that there should be an absolute abeyance of competition, even in the ordinary sense, and whether as buyer or seller. When a large percentage of the business in a particular industry is under one control, smaller concerns will frequently take advantage of the prices fixed by the big business rather than risk extermination in a carnival of competition. Under such conditions the big business enjoys a monopoly in the sense of the term as I use it. Even where the smaller concerns have their own scale of prices, the big business will enjoy a monopoly so long as its own scale of prices is not affected, to any appreciable extent, by the prices of rival concerns. Finally, a monopoly may exist in a protected community although the danger of competition from abroad may prevent a local trust or combine from raising prices above a certain level. 
The term trust, like the term monopoly, is used in various senses. I mean by a trust any large consolidated business which enjoys a monopolistic control. I oppose to the term trust, which implies a unity of administration, the term combine. By the latter, I mean a union of several more or less independent concerns for the purpose of excluding or limiting competition. The combine, so defined, may or may not be a monopoly according to the circumstances of the case. While the trust and the combine do not exhaust the field of monopoly, they are the most important types. Public monopolies are beyond the scope of the present work. ${ }^{1}$

\section{Monopolies and THE Community}

The tendency towards the formation of monopolies, trusts and combines is the outstanding feature of modern capitalism. Whether we like the tendency or not, whether we regard it as healthy or unhealthy, it is in any case a fact to be reckoned with. While it may eliminate the wastes of competition, it deprives the producer, the employee, and the consumer of the protection which competition has afforded to them in the past. Hence the practical problem, What new safeguard can be devised?

The solution of the problem just indicated is not simple. But reformers who have given serious attention to the subject may be divided into two groups according as they rely mainly upon

1 For a classification of monopolies, the reader is referred to the work of Professor Ely. 
extensions of the sphere of public control or upon the organised action of private associations. The latter class finds its most active exponents in the ranks of those who urge the confiscation and management of industrial capital, irrespective of its monopolistic or competitive character, by existing employees. A movement, usually described as syndicalism, dominates Trade Unionism in France and has rapidly extended to other countries. I propose, in the succeeding chapter, to explain its meaning and origins, and to discuss its merits and practicability as a scheme of economic reconstruction. The reader who regards syndicalism as a passing phase, or as a movement beyond the scope of a work on the control of monopolies, will probably pass to Chapter III. But the reader who attaches as much importance as I do to the syndicalist movement, and who realises the intricate interrelations of the problems which arise out of monopolistic and competitive capitalism respectively, will concede the desirability of an examination of the claims of syndicalism. If those claims be well founded, a discussion of the forms of public control of monopolies may be dispensed with. The problem of monopolistic capitalism should be regarded as but one aspect of a wider problem which should be solved in other ways, and through other agencies, than commend themselves to those reformers who advocate a progressive extension of the sphere of public control. 


\section{CHAPTER II}

\section{SYNDICALISM}

\section{The Character of the Movement}

SYNDICALISM is understood in different senses. ${ }^{1}$ The form of syndicalism which I discuss in the present chapter is distinguished by its objective and programme. The objective is the ownership and control of the means of production and exchange by the trade unions. The programme is confiscation of industrial capital by means of the general strike, shirking, sabotage and such other expedients as may tend to make the modern capitalist scheme unworkable. To the claim of vested interest, the syndicalist opposes the claim of the labourer to enjoy the fruit of his labour. He declares that the capitalistic class is parasitic ; and that the purposes which capital should serve can be secured most effectively if the ownership of the means of production and exchange is vested in those by whose labour capital is made productive.

Syndicalism is allied to anarchy in its resolution to overthrow the existing order. But its programme of action is distinct, and its objective is not self-government in the anarchist sense, but

"Cf. "The Real Syndicalism," by H. Warner Allen in Cornhill, February 1914. 
a type of industrial organisation. It even contemplates a regimented social order, although at present the nature of this order is ill-defined. It declares that the primary and essential thing is to gain possession of the means of production; and it appears to assume that the solution of other problems will be comparatively simple when once the primary object is achieved.

Both the syndicalist and the anarchist, in their antipathy to the existing order, find an ally in the socialist. But beyond this common antipathy, harmony gives place to discordant controversy. Unfriendly critics represent them as burglars who have agreed upon a raid, but not as to the distribution of the "swag." Among the many respects in which syndicalism differs from socialism, the following are cardinal. (I) It aims, not at State or municipal ownership, but at trade union ownership. (2) It seeks to achieve its ends, not by means of Parliamentary action, but by the general strike. (3) It is a class movement in a sense that socialism is not. Socialism aims at a reconstructed social order which shall embrace the whole community; and it finds its champions or representatives in every existing social class. Syndicalism is frankly sectional. (4) Socialism has been much longer in the field; it has undergone a long ordeal of acute and hostile criticism; and, though many of its former tenets are now discredited, it offers to the reformer a more definite and reasoned scheme of social re-organisation than has so far been presented by syndicalism.

Syndicalism must be distinguished, not only 
from anarchy and from socialism, but also from the policy which advocates the purchase and control of industrial concerns by wage-earners. Some reformers have urged that the trade union, while maintaining its political campaign, should supplement that campaign by an investment of its funds in various forms of business enterprise. I cannot discuss here the merits or demerits of this proposal. I only refer to it in order to distinguish it from syndicalism, which advocates a frontal rather than flank attack on capitalism, and prefers confiscation to purchase.

\section{ORIGINS}

To many observers, syndicalism is apt to appear as the spectre of a disordered imagination. An impartial examination, however, if it does not serve to justify the movement, will at least explain its appealing power. In the first place, syndicalism is a protest against the dominance of the "intellectuals." The protest is usually represented as an appeal to the intuitions of men in preference to the theories or doctrines of the schools. If we look a little deeper, however, the protest will be found to be a form of asserting human equality. The ideal of equality, traditionally a protest against the pretensions of an aristocracy of birth or wealth, easily passes to a jealousy of claims to superior wisdom-especially where these claims are accompanied by the expression of unpalatable conclusions. Thoughtful socialists, in their endeavour to meet the criticisms and difficulties incidental to social 
re-organisation on socialistic lines, have made concessions which offend or disappoint a large body of followers. Syndicalism is the insurgent spirit of democracy à outrance. While in the ranks of syndicalists may be found eminent writers who endeavour to present the movement as a reasoned faith defensible on philosophic grounds, the influence of such writers appears to be negligible when considered as a factor in determining the essential character and strength of the movement itself.

Apart from its distrust of the "intellectuals," syndicalism owes much of its appealing power to an impatience of the method, the tactics, the intrigues, and above all the tardiness of Parliamentary action. This impatience, if not commendable, is at least comprehensible. A reflective legislator once remarked, "I have been twelve years in Parliament. When I first entered, I told my constituents that I was going to do a lot. Of the measures for which I have been responsible, only one has been carried into law. I am bound to admit that it has proved to be one of the worst laws on the Statute Book." The disillusionment may be tragic: there is no reason to regard it as remarkable. The Parliamentary candidate promises much; he achieves little, and the little that he does achieve may prove barren or even mischievous. The politician may be wiser than most of his critics, with a wider outlook, and a real desire to get forward. But the problems with which he has to deal are so numerous and complex, the forces which he has to combat are so potent, the vested interests so entrenched, the 
pitfalls so numerous, that just in proportion to the intensity of the social will in him is his disappointment or disillusionment acute. He feels that the little which he does achieve is insignificant in comparison with the things which ought to be achieved. And if the Parliamentarian feels this, the elector will feel the same thing-feeling it more intensely because he has not had the same opportunity of acquainting himself with the difficulties of the problem of social amelioration. More especially, if the elector is a- worker, the suspicion of Parliamentary ineptitude is strengthened by the belief that the whole atmosphere of Parliament is charged with influences which are hostile to the working class view, and destructive of the enthusiasm and ideals of the elected Labour leader.

In the case of the syndicalist, the impatience of Parliamentary institutions is accompanied by an invincible distrust of the present economic structure of society. The distrust is intensified by the growth of monopolies, but it originates in the general conditions of modern capitalism. To an impartial observer, it ought not to appear remarkable. One can imagine a newspaper correspondent from Mars writing to the Martian Press as follows: "European society to-day represents the final results of a civilisation which for many centuries has proclaimed a gospel of human brotherhood. We are therefore entitled to assume that the laws and institutions assure equal justice and equal opportunities to all. There are, however, anomalies for which I have yet to learn the justification. For one thing, quite a large number 
of people live in luxury without sharing in the toil by which this luxury is made possible. The explanation of this curious arrangement may be that society wishes to exempt those individuals from toil in order that they may set an example of beautiful and high-souled living. In support of this explanation I may remark that the women of this class devote great effort to their personal appearance; and some of them dress beautifully. In this way, they uphold a standard of the beautiful which ought to be of great service to the community. Unfortunately, the standard is of little advantage to the many for lack of the means to profit by it. Indeed, it is a curious fact, but I have not remarked among the women of this class any clear indication of a desire that their humbler sisters shall be able to profit by the standard they uphold. Doubtless there is an explanation; but I have yet to learn it. With regard to the men of this class, I find even greater difficulty in understanding why they are held in such high honour. They do not dress beautifully. Possibly, however, we should regard the fact that they are permanently endowed by society as a proof of the value of great services which they may have rendered in the past. I mentioned this possibility to a person whom I met in the street. $\mathrm{He}$ used strong language. He even called me a fool. He said that the class in question was, for all practical purposes, an hereditary caste which had captured the means of production and used its power for selfish ends instead of the public good. I do not understand exactly what he meant by the means of production. Nor am I 
disposed to attach great importance to what he said. He was discontented; his manners were deficient; and he wore a red tie which I am told is a symbol of revolution. But apart from these things, he appears to me to have ignored the fact that the exalted faith which European civilisation has professed for many centuries is highly esteemed by the very class which he was attacking. However, I will think further over this matter and report later the result of my investigations."

Pending the arrival of this later report, I venture to submit a few questions. Does not the present capitalistic system, notwithstanding its achievements in various fields, lend itself to flagrant exploitation of class by class? Have not Parliamentary attempts to regulate that system failed to prevent glaring contrasts of poverty and wealth, or to eliminate the social parasite? Is there even a reasonable approximation to a just distribution of the national dividend? Are there not glaring disproportions between the service which men render to society and the income which they receive? Has the enormous increase in the productivity of the labourer, due to man's increasing control over the forces of nature, brought about any comparable improvement in the conditions of the labourer? If not, why not? If we ponder over these questions, with a will to be just, to get at facts, and to draw honest conclusions from those facts, we will understand many things that might otherwise seem inexplicable. Those who regard syndicalism as a mere gospel of robbery misapprehend the movement. If the movement could be so regarded, it would 
never have acquired its present importance. That importance consists in the fact that syndicalism expresses the angry and bitter protest of those who believe themselves to have been defrauded of their rights and their heritage by an economic order which involves a cruel denial of social justice. The co-existence of colossal fortunes with degrading poverty, the frequent divorce between the control of wealth and a due sense of its responsibilities, and the obstacles which the present economic system places in the way of men discharging those functions for which their capacity is adapted-these bring more grist to the syndicalist mill than all the preaching of the syndicalist agitator. The social unrest of our times arises not so much from hunger as from thinking. The thinking of the syndicalist may not be impartial; but it is vigorous; and it finds ample food for thought in the anomalies to which I have referred.

A further explanation of the syndicalist revolt deserves special consideration. That explanation is the difficulty of subordinating the power of capital to the good of society without confiscating the means of production and exchange. The syndicalist, in older countries at any rate, finds one class living in relative luxury, while the majority of the community live on the border-line of poverty. He discovers an explanation in the concentration of capital in the hands of a few. $\mathrm{He}$ advocates the diffusion of capital among the rany. When he comes to the question of effecting this diffusion, he repudiates the notion of public ownership. Extensions of public owner- 
ship imply Parliamentary approval. Parliamentary approval, he urges, is only possible, in a community where the forces of capitalism are strongly entrenched, at the price of compensation to existing owners. Such compensation means that the propertied classes levy their toll in another form. They receive an annuity in the place of a dividend. To the syndicalist, this solution of the problem is mere jugglery. He turns, therefore, to the more obvious solutiondirect and immediate confiscation by the employees.

The difficulty of controlling the forces of capitalism in the interest of society is a theme upon which it would be easy to elaborate. The impartial student must admit that the need for this control is rarely recognised by the capitalist, and that the difficulty of effecting the control is seldom appreciated by the reformer. Mr. Hilaire Belloc, in his recent work on "The Servile State," maintains that the ownership of the means of production and exchange has passed into the hands of a class which is virtually parasitic; and that the drift of legislation, actual or proposed, is toward the permanent endowment of this parasitic class. In other words, the great body of the citizens has forfeited, or is in process of forfeiting, its birthright of freedom for a mess of pottage, to wit the security of subsistence afforded by Employers' Liability Acts, Social Insurance Acts, and the legislative recognition of the minimum wage with its corollary of compulsory labour. England, urges the author, is drifting towards the Servile State. The reader of Mr. 
Belloc's book will comprehend the point of view of the syndicalist with whom Mr. Belloc would disclaim sympathy. Syndicalism will only appear altogether monstrous to those people who, whether from ignorance or from prejudice, from inability to think things together, or from disinclination to face unwelcome facts, have failed to realise how immensely difficult is the problem of subordinating the power of modern capital to the well-being of the modern community. I may illustrate this remark by an extract from the daily press. "People who attack capital may mean well ; but they do not know what they are doing. Capital is invulnerable. Increase the wages of the employees, and the capitalist more than recoups himself by enhanced prices for commodities. Nationalise an industry, and the capitalist draws a more secure income from the State to which he lends money to buy him out. The sooner people realise that capital is better left alone, the happier for all concerned." It is easy to anticipate the answer which the syndicalist would make to such remarks, and to understand why he urges a frontal attack on capital.

\section{Critical Examination of Syndicalism}

I have stated very briefly the objective of syndicalism, its programme of action, and the conditions which contribute to its acceptance. I cannot stop, however, at this point. I have to discuss the problem of monopoly. Syndicalism attacks the whole system of modern capitalism. 
If the syndicalist be right, the problem of monopolistic capitalism is only a part of a larger problem; and the proper procedure is to solve this larger problem in a particular way. I am compelled, therefore, to examine syndicalism from a more critical point of view. In doing so, I wish to recognise frankly the force of the facts to which I have referred. Social reform through Parliamentary action has been slow, and often ineffective; the economic structure of society tells for a very inequitable distribution of the national dividend; and neither legislative action nor public opinion has succeeded in controlling the forces of modern capitalism in the public interest. But a theory of reform, such as syndicalism purports to be, must give us something more than a forcible criticism of existing institutions. It must be constructive as well as critical. It must show, not only that grave evils exist, but also that a remedy for those evils can be found, what the remedy is, and how it is to be effected. I proceed, therefore, to examine syndicalism in its more difficult and constructive aspects.

The first thing to consider is whether the syndicalist theory of reform is based upon a just view of the order which is to be reformed. The most plausible theory may be foredoomed to failure if the reformer is too captivated by his vision of the future to be just to the conditions of the present. What, then, is the syndicalist view of the nature of the society which he proposes to reconstruct? The answer must be that he views society as a mere aggregate of two classes whose interests are severable and antagonistic- 
the capitalist or exploiting class, and the labouring or exploited class. Or, to put the matter in other words, the great majority of the citizens in the social organism languish because their life blood is being absorbed by a parasitic capitalism. Is this view in accordance with fact? If so, the social data of syndicalism, if not the remedy, are justified. But if not, the sooner the syndicalist revises his social data, the better for the cause which he has at heart. Exaggerations or distortions do more than anything else to discredit great causes. I have a recent and apposite example in mind. In his book on "The Condition of England," Mr. Masterman suggests that modern poverty is the result of modern "super-wealth." He estimates the aggregate incomes of the super-wealthy at $£ 200,000,000$. Mr. Mallock shows that more reliable data assess this aggregate income at $f \mathrm{I} 30,000,000$. Now the total income of the nation is not less than $£ 2,000,000,000$. In other words, the super-wealthy receive only $6 \frac{1}{2}$ per cent. of the annual dividend. "What is essential to the construction of any sound social policy," writes Mr. Mallock, "is not a knowledge of social facts taken separately, but a knowledge of the proportion which each bears to the rest; and when Mr. Masterman declares that super-wealth, by reason of its brute mass, is causing the whole structure of society to give way at its very foundations, he might just as well say that a tower a hundred feet high is crumbling under the weight of thirty inches of ornamental battlements." I I do not propose to

1 The Nineteenth Century and After, April I9I3. 
hold the balance between the ultimate conclusions of the writers just quoted. But the fact that I am more in sympathy with Mr. Masterman than with Mr. Mallock affords me a reason for expressing a warning against those who, by their unconscious exaggeration or distortions, invite ridicule at the expense of the cause which they seek to defend.

In considering whether modern capitalism is parasitic we have to guard against two dangers. One of these dangers consists in abstracting capitalism from the capitalist. Capitalism is apt to be regarded as a mysterious something which we can praise or condemn without reference to the functions which the capitalist may discharge. Capitalism is not parasitic unless the capitalists are parasitic. Another danger is that of judging the "capitalistic class" by reference to particular individuals or groups of the class. The social value of no human institution that ever existed can be determined in this way. The argument from the particular to the general equally lends itself to extravagant praise and extravagant censure. Bearing those dangers in mind, it will be apparent that the so-called capitalistic class requires to be divided into several groups. The first group includes those who are parasitic in a real sense. They draw their income from capital which they have not earned; and they expend their income in ways which indicate a strange disregard of social responsibilities. "The Duke of Blankshire receives an income of $£$ roo,000 a year. In return he shoots partridges!" The second group consists of those who, though they 
do not work for a livelihood, yet serve society in other ways-in public or philanthropic work, in the promotion of reform, of learning, morals or religion. To call the group parasitic is inaccurate. It includes some of the hardest-worked, some of the ablest, and some of the most public-spirited members of the community. The third group includes those who, by lucky speculation, industry or ability, have made their fortunes and are living on the proceeds. The members of this group may or may not be parasitic, according to the circumstances of the case. Some of them have contributed more to the national wealth in a few years than a hundred ordinary men contribute in a lifetime. The fourth group consists of those who share in the work of production, either as independent producers, or as captains of industry in business concerns in which they are financially interested. They may receive too much for what they do; but to call the group parasitic is an abuse of language. The group includes members who represent much of the business brains of society, and who devote their energies to the work of making capital and labour more efficient. Greed or ambition may or may not be an impelling motive; but in any case they serve the community in a capacity which becomes increasingly important as industry becomes more complex. The fifth group includes a large proportion of society. It includes those who work for their livelihood in other capacities than those previously indicated, but receive, in addition to income from personal exertion, a further income from capital which is representative of past 
savings. Most depositors in the Savings Bank are members of this group.

The above classification of the capitalistic class is not exhaustive. It is, however, for practical purposes, a sufficient presentation of the more important types. If we are to work for the future, we should work on a basis of fact, not on a basis of fiction. To affirm that the disease from which the social organism suffers is to be cured by the surgical process of excising the capitalistic class, on the ground that the class is merely parasitic, is to betray a false diagnosis. Some members of that class are parasitic; other members may receive a return for their services out of all proportion to the value of those services; and these evils may demand a more or less drastic revision of existing laws and institutions. Even so, the advocate of any particular form of revision should be just to the facts of the present if he wishes to convince us of the wisdom of his plans for the future.

The social diagnosis of the syndicalist is wrong in another way. It exaggerates the extent to which, under existing conditions, the interests of capital and labour are severable and antagonistic. No doubt capital and labour are often in conflict. The one wants cheap labour. The other wants a high wage. But the conflicts which divide them are slight in comparison with the interests which they share in common. Wanton attacks on capital decrease employment; bad conditions of labour or low wages tend to make capital unproductive; and in proportion as capital is efficient, the wealth of the community 
increases, the demand for labour increases, and this increased demand tells for security of employment, for higher wages, and for better conditions of labour. To contrast capital and labour as if they were wholly antagonistic, so that a gain to one is a loss to the other, is to return to the discredited theory of society as a kind of mechanism. Society is not a mechanism, but an organism. Even excessive returns on capital, or excessive profits to the man who borrows capital, have to be spent or invested. If they are spent, they increase the demand for goods, and therefore the demand for labour. If they are invested, they also increase the demand for labour. Perhaps no more significant illustration of the essentially organic structure of society could be quoted. An illicit enrichment of an individual or class cannot be wholly abstracted from the common interest. By invincible necessity some part of that of which the wage-earner may be defrauded comes back to him in indirect ways. The fact is so obvious, and so frequently made a pretext for grotesque conclusions by the apologist of the status quo, that I should hesitate to refer to it but for the growing disposition among some workers to regard the profits arising from the use of capital as a net loss to the community.

Let us, then, face the facts. Neither the capitalist as such, nor the trade unionist as such, is the enemy to society. The enemy to society is the parasite in the one class, and the revolutionary extremist in the other. Both, though in very different ways, constitute a menace to the stability of the social order, and to its development 
by evolutionary process. The parasite is an offence to the moral sense, and affords a colour of justice to predatory attacks upon capital ; the revolutionary extremist in the ranks of labour is a blind Samson, potent to destroy, but lacking in knowledge, in understanding, and even in the will to act justly. Both are enemies to the class to which they belong rather than to the class to which they are opposed.

The syndicalist view of society as a mere aggregate composed of two classes of owners and wage earners, whose interests are severable and antagonistic, is false negatively as well as positively. It overlooks other group conflicts which tend to acquire an increasing importance in economic evolution. "In my judgment," said Mr. Balfour when addressing the Sociological Society in Igr2, "we are too much in the habit of always talking as if the competition and conflict of interests in modern industrial societies were between capital on the one side and labour on the other. No one can deny that there is some such competition and conflict of at least apparent interests. But a more essential and universal and a more necessary form of competition is that between different industries, between those who make and those who buy, between those who extract coal and those who use coal, and no rearrangement of industries within themselves can do anything whatever to diminish that conflict of interests which, so far as I can see, is absolutely inevitable. Competition will therefore go on, both between the industries in the same country and between the same industry in 
different countries, and between each industrial group and all other industrial groups. Do what you will in the way of syndicalism, or any other arrangement, you cannot mitigate these evils."

Mr. Balfour's remarks derive a special significance when they are viewed in relation to the development of the trust. The trust prefers to make its profits out of high prices to consumers, rather than out of low wages to employees. In other words, industrial peace is secured as a means of more effectively fleecing the general public. "The art of taxation consists in plucking the goose with the minimum of hissing." The trust is less concerned about the hiss than about the bite. Consumers grumble; but workmen go out on strike. As between these alternatives, the latter is the more dreaded in the policy of trust finance. Though the wage-earner is also a consumer, he stands to gain far more by an increase of wages than by an increase in the price of the commodity in which the trust deals. The-situation affords an arresting illustration of the forms of group antagonism to which Mr. Balfour refers.

Although the syndicalist is guilty of exaggerations and omissions in his account of the existing order, it does not necessarily follow that the remedy which he proposes is altogether wrong. All reformers are liable to see things out of their true perspective. Unfortunately, in the case of the syndicalist, the exaggerations and omissions are serious, and his remedy is not independent of his social data. It is a strict logical deduction from them. It is inorganic in the same sense 
as his social data are inorganic. Social amelioration is to be brought about through the selfcentred triumph of a class. Since the so-called vested rights are "vested wrongs," existing owners are to be treated as if they had no claims for consideration.

No one will deny that a time may come in the history of a people when the interests of the few should be sacrificed to the interests of the many. I will assume, for the sake of argument, that the confiscation of capital is necessary. Even so, justice and prudence alike demand that the confiscation should be effected with all possible regard to the claims of those whose wealth is to be confiscated. Otherwise, a grave injustice will be inflicted, and the evil results of that injustice will not be limited to any one class. If, for example, Great Britain nationalises the railways without paying compensation to present owners, it will reduce a large number of people to destitution, and it will also throw into confusion the whole economic order. That order largely exists on a basis of credit and confidence, a confidence that society will not ignore rights which have been acquired by its permission and approval. If, then, the railways are to be nationalised, the present shareholders should be compensated. The immediately essential thing is a more equitable distribution of the national dividend. This may be effected through legislative regulation of the rate of wage and conditions of labour, through extensions of public ownership where desirable, through the application in certain cases of a time limit as in the Licensing Bill of I908, and by a 
continuous readjustment of the incidence of taxation, including in taxation a progressive toll on bequests. Such measures of reform may involve a gradual confiscation within the accepted meaning of the term. But I am assuming for the moment that confiscation is necessary; and my point is that, if it is necessary, it should be effected with a due regard to the interests of all parties and the welfare of the community. We ought not to inflict needless suffering on particular individuals; and we must not be so obsessed by a zeal for effecting a more equitable distribution of wealth as to lose sight of the dangers which would be involved in a brutal shock to the existing system of credit.

Syndicalism must be judged, not merely by reference to its advocacy of prompt confiscation, but also by reference to its proposal to effect confiscation by means of a general strike. The implied censure of Parliamentary institutions is significant and characteristic. How far is it justified?

Undoubtedly, social reform through Parliamentary action has been slow, tedious, and often ineffective. A partial explanation may be found in the character of the problem of social amelioration. There is no royal road to success; and it seems a priori improbable that there is any short cut to the reformed social order. I know that many people think otherwise. All is to be well if the State owns the land! Or if the State owns everything! Or if both State ownership and individual ownership are abolished! Or if the capitalist be abolished! Or if law be abolished! 
To discuss these various proposals is, for present purposes, unnecessary. It is enough to say that if any one of them be right, and if it is to be given effect to in such a way as to ensure good and enduring results, there must be hard thinking, sustained effort, and a persistent regard to all the factors of the problem, to all the interests of society, and to all the varying elements of the social structure. The American injunction, "Young man, since the elevator to success is not running, take the staircase," applies to the social as well as to the individual life. Social reform through Parliamentary action is slow partly because the reform of a thing so complicated as the economic structure of society is beset with innumerable difficulties. It only seems simple to those who close their eyes to all but a few facts-facts which, when regarded in isolation, are apt to be little better than dangerous fictions.

An ignorance of the difficulty of the problems with which Parliamentary institutions have to deal is only one reason why those institutions have been judged unfairly. Another reason is the growing disposition to expect too much of them, and to ignore the need for individual and collective action in co-operation with them. There are Trade Unionists to-day who expect the Labour Member of Parliament to do everything, while they remain quiescent, oblivious of the fact that Parliamentary effort for the betterment of labour conditions needs to be supplemented by active and organised effort outside of Parliament. There are consumers who grumble about prices, but will not trouble to do anything to protect themselves. 
There are producers who are the victims of monopolistic control, because they will not take the trouble to co-operate under the conditions, and subject to the sacrifices, which co-operative enterprise demands. There is to-day, not in one class only, but in all classes, too much of the attitude which expects others to do the things which are to be done, too little of the attitude of the individual who asks, What can I myself do ?

Even conceding that Parliament, as an engine of social reform, has proved a relative failure, the natural remedy would seem to be found, not in the repudiation of Parliament, but in its reform. In the first place, this means an improvement in the structure of Parliament, a broadening of the franchise, and an improvement of the methods of election. The day for the hereditary legislator is past. The day for the restricted franchise in an Anglo-Saxon Community is past. Even in countries which enjoy adult suffrage, the methods of election are often ill-adapted to secure a truly representative legislature. In the second place, the reform of Parliament means the reform of the electorate. More education, better education, and above all a more widely diffused consciousness of the obligations of citizenship-these are primal necessities. When the citizen can think for himself, will take the trouble to think for himself, and above all when he can learn to subordinate his class interest to the common good, to be loyal to his group while preserving his larger loyalty to society, we shall have a reformed Parliament; and the progress towards a reformed social order will be at once more rapid and more 
secure. In the meantime, "Let us not forget fundamentals."

But the syndicalist is too impatient to trouble about the natural and obvious lines of development to which I have referred. Parliamentary institutions can go their own way; he will go his-the way of the general strike. His general strike is not the mere stoppage of work for some particular and immediate purpose, such as an increase of wages, an improvement of industrial conditions, or the prevention of a threatened war between two nations. The general strike of syndicalism is a means to effecting a complete and immediate revolution of the economic system. The means necessarily involve social chaos. I believe that, while this chaos would inflict a grave injury upon all classes of society, it would prejudice most seriously the very class for whose welfare the syndicalist is fighting. "The general strike of syndicalism," writes Mr. Ramsay Macdonald, "empties markets, raises prices, and stifles consumption throughout the community. And what does that mean? It hits the poor people heaviest, the middle classes next, and the rich least of all. . . . The syndicalists assume that when the general strike comes time will be on their side. Exactly the opposite is true. Time will be against them. ... As the days go, society will organise itself against them, because society, as well as the individual, is moved by the Will to Live." 1 "In every general strike which has taken place," writes Mr. Philip Snowden, "it is the workers who have suffered most.... In the

1 "Syndicalism," pp. 62-4. 


\section{IMPRACTICABILITY OF GENERAL STRIKE 29}

words of the German Social Democrats, the general strike is general nonsense." 1

In order to triumph, syndicalism would have to persuade public opinion of three things: the merits of its ideal of industrial organisation; the justice of bringing about that organisation by a ruthless confiscation of capital ; and the justification for effecting confiscation in defiance of the spirit of the constitution and the laws. What are the chances of converting public opinion to these things? The answer may vary with different countries. Speaking of communities within the Empire, I think the chances are wholly against the syndicalist. The innate conservatism of the average mind is against him; the traditional preference for reform through legal and constitutional action is against him; the inertia of the many and the power and self-interest of the few are against him ; the power of established institutions, opinions and beliefs are against him; the democratic organisation of the modern community is against him. The syndicalist places great reliance upon the tendency of industrial organisation to increase the ratio which the class of employees bears to the rest of the population. He urges that the employees now constitute, or will soon constitute, an overwhelming majority, that he can persuade this majority to adopt proposals so apparently to their advantage, and that adverse opinion will necessarily yield before superior numbers. But if an overwhelming majority could be converted to the objective of syndicalism, its programme would be unnecessary.

1 "Socialism and Syndicalism," p. 236. 
The real fact is that the syndicalist is not content to wait for the approval of public opinion. $\mathrm{He}$ proposes, therefore, to compel it by a parade of force. In making this proposal, he alienates forces which might otherwise have been with him ; he provokes resentment where he might have gained co-operation. $\mathrm{He}$ is gambling with the interests of the worker he professes to befriend.

In the preceding argument, I have discussed the programme of syndicalism rather than its scheme of industrial re-organisation. It is, indeed, difficult to discuss a scheme which exists in a form so vague and indefinite. At an early stage, the view was held that each trade union should take over an industry and run that industry for the profit of its members. The absurdity of such an arrangement, as a means of securing distributive justice, is so apparent that it has been abandoned. The view now held is that, although the trade union should own and control its appropriate industry, the product of the industry is to become the property of a Confederation of Trade Unions embracing the whole body of organised workers. While such an arrangement meets some criticisms, it invites others. Hence among syndicalists an aversion to attempts to give to their objective a definite form. Every increase in definiteness raises new difficulties, offers new objects to attack from the enemy, and invites dissension within the camp. But the present aversion to "schematising" cannot be indulged indefinitely. When this fact is once recognised, the most serious of all obstacles to the triumph of the movement will be manifest. 
The syndicalist cannot hope to win public opinion without showing that his scheme of industrial organisation will work. In his attempt to show that it will work, he will be impelled to make concessions as to the need for intelligent direction and disciplinary control-concessions which must weaken the appealing power of the movement to insurgent masses. "It is quite evident," writes Mr. Philip Snowden, "that the scheme which the syndicalists have at the back of their minds is not only an utterly impractical one, but one which if realised according to their ideas would not abolish the wages system and would not make the workshop a self-governed institution. The Co-operative Movement has always had before it the ideal of the workers managing industry, but it has found it to be altogether impracticable. The system of giving the workers a share in the profits has been found to work with more or less success, but in co-operative production the management has had to be on precisely the same lines as in private concernsnamely, entrusted to individuals who had the necessary technical knowledge and directive ability. It requires little imagination to conceive the chaos which would immediately result if the management, say of a coal mine, were in the hands of all the thousand miners working in the pit. Syndicalism could not escape from an elaborate organisation. Though it does not recognise the need for directive skill, nor for individuals with exceptional technical knowledge, it could not run its workshop a single day without delegating functions to individuals who would have 
to exercise disciplinary powers over bodies of workmen. . . . It may be argued that the workmen would elect their managers and directors, and would have the power to dismiss them. But if the workmen's control over the management was limited to electing and dismissing managers, it would be but a mockery of the power which syndicalism promises the workmen." 1

\section{Underlying TRUThs IN Syndicalism}

One subject in relation to syndicalism deserves the careful consideration of every citizen who is interested in the cause of social reform. A movement which has spread so rapidly, whatever may be its fallacies, must have in association with those fallacies some elements of truth which deserve statement. What are these elements?

They are implied in my brief account of the conditions which explain the origin of syndicalism. I shall now endeavour to make a more formal statement. I wish to do so for two reasons. (I) I believe syndicalism to be a real menace to social progress. If we desire to confute a false theory, or to cope with it in the arena of practical affairs, we dare not ignore the truths bound up with it. We must dissociate those truths, and state them at their full value. We need not think this a superfluous task if, as in the case of syndicalism, many of the truths are not remarkable for novelty. Between the formal statement of a principle, and its understanding and whole-hearted acceptance, lies a gulf which the 1 "Socialism and Syndicalism," pp. 239-40. 
reformer can only hope to bridge by patient and persistent reiteration. (2) Although the present work is concerned with monopolistic capitalism, while syndicalism attacks the whole system of capitalism, the more important elements of truth in the syndicalist creed have no less significance in the limited than in the wider field. On the contrary, that significance is the greater. My chief reason for devoting a whole chapter to the subject of syndicalism is the opportunity afforded of preparing the way for a statement of certain fundamental verities which we have to bear in mind both in order to realise the need for the prevention, regulation and control of monopolies, and in order to ascertain the means by which these purposes can be best effected.

In the first place, then, wealth is less an individual than a social product. Let us suppose the case of a man who makes a large fortune by the supply of some commodity. Soap, let us say! We shall suppose him to be fair-minded and just. He does not resort to the tricks of the trade. His wage bill is fair. He is able to supply some public want more cheaply than his rivals because of his better business qualifications. By supplying a cheaper article which is not an inferior article, he is at once a profit earner and a public benefactor. I take the case least favourable to my present argument. I do not select a black sheep, and declare or suggest that it is typical. I want to appeal, not to the emotion, but to the reason. But even taking the case I have supposed, what are the facts as to profits? Those profits are due, only in the most partial way, to 
the man himself. To assign the credit where it is due, we must take into consideration the genius, the labour and self-denial of inventors whose work he has been able to utilise; we must take into consideration the complex machinery of the State which, in a thousand ways, supplements his effort and protects the fruit of that effort ; and we must take into consideration an industrial organisation without whose co-operation his achievement would be insignificant. His wealth is a social rather than an individual product. That he should be rewarded for his zeal and ability may be just and expedient. But the first step towards a view of the real as distinct from the imaginary claims of property is to recognise its social origin. The man who says "I have accumulated this wealth by my own effort, and my rights with respect to it are therefore absolute and indefeasible," builds on a lie. $\mathrm{He}$ is affording a pretext for the worst extravagances of which the syndicalist is guilty.

In the second place, the protection of private property and its fruits is only subsidiary in the general scheme of the purposes of associated human life. It has been often declared, still oftener implied, that the supreme end of the State, its controlling and decisive purpose, is the maintenance of property. The view has been outgrown. The State exists to promote social and individual well-being. Private property is only an element in this well-being; and it must be viewed in its true relation to other and more important elements. An exaggeration of the claims of private property is one of the gravest sins of the social order. Even Religion has often 
forgotten its high mission, and become subservient to class interests. Morality and Law have conspired to throw an undue emphasis upon those interests. "The slightest invasion of property," says M. Charmont, "is represented as dishonourable. The man of honour is he who would allow his wife and children to starve rather than lay a finger on the property of another." ' Man is more than Property; and the recognition which a community gives to property, the extent and the forms of that recognition, should be conditioned by the claims of the members of the community to their free self-development as rational beings.

The value of the institution of private property, as a stimulus to initiative and enterprise, must be conceded. But the claims of private property, based on this ground, cease to be convincing or even respectable when they are urged in the exaggerated form with which we are so familiar. "If you do not assure to each his own, men will cease to build up large fortunes. The economies, the efficiency, the initiative of large concerns will be imperilled; and society will be the poorer." The answer to this reasoning is twofold. For one thing, when it is a case of assuring to each his own, we have to remember that wealth is a social not an individual product, and that the question of ascertaining what is a man's own is not a question to which the answer can be left to the individual himself. For another thing, it is quite possible to stimulate business enterprise without sanctioning conditions which we see around us to-day-

1 "Le Droit et L'esprit Démocratique," pp. 52-3. 
conditions which threaten to result in an irresponsible plutocracy. This is so, even if we look at the subject from a strictly individualistic point of view. As an eminent individualist declared long ago, "The institution of private property as actually existing goes beyond what the individualistic theory justifies. Its general aim is to appropriate the results of labour to the labourer, but in realising this aim it has inevitably appropriated natural resources to an extent which, in any fully peopled country, has entirely discarded Locke's condition of leaving enough and as good for others. In any such country, therefore, the propertied classes are in the position of encroaching on the opportunities of the unpropertied in a manner which however defensible as the only practicable method of securing the results of labour, yet renders a demand for compensation justifiable from the most strictly individualistic point of view." 1

Implicit in the foregoing remarks are two conclusions upon which syndicalism lays great emphasis. (I) Every citizen who can work should work. He should be a producer in the wide sense of the term. We want no drones in the social hive. (2) There is an apparent and urgent need for reforms which, in one way or another, will tend to ensure a more equitable distribution of the national dividend. I state these conclusions in the broadest possible terms. The moment one comes to the question of ways and means, or to the question of the extent to which in practical statesmanship the recognition of the conclusions

1 Sidgwick, "Elements of Politics," Second Edition, p. I63. 
just stated must be qualified by complementary considerations, a thousand difficulties arrest our progress. I wish for the present to keep to common ground. And I believe that it is common ground with all persons who are seriously and honestly interested in the problem of social amelioration that the day is past for passive acquiescence in the glaring disparity which now exists between the income men receive from society, and the services which they render to society.

So far, the earnest reformer, of whatever school, can agree with syndicalism. But the common ground extends further. The fact that property is a social rather than an individual product has a special significance in an age of concentrated capitalism. We are confronted by a new problem of the gravest menace. People may differ as to the solution of the problem. The syndicalist has one solution, the socialist another, and the conservative reformer yet another. But despite these differences, the need for new forms of control is apparent and imperative. Dr. Mackenzie King expresses the situation briefly and forcibly. "Organisation on a large scale is alone rendered possible by the peace and security which the State assures, and in the maintenance of which the heaviest expenditures of government are incurred. The facilities of transportation and communication, of banking, of credit, on which industrial combinations are dependent for their very existence, are the outcome of concessions made by the public, and are in the nature of agencies promoted by the aid, or at the expense of, the State. In other words, an organised community is essential 
to the work of production and distribution; and the extent of organisation determines in large measure the possibilities and degree of both. In this view of the relation of industrial combination to the community, it becomes the duty of government to see that the interest of the many who compose the State are not sacrificed to the interests of the few whose powers and opportunities they have helped to create." I

One special aspect of the problems which arise out of concentrated capitalism seems peculiarly adapted to afford a colour of plausibility to the propaganda of syndicalism, and is specially relevant to the subject matter of the present work. I allude to the growth and powers of trusts and combines. Each day sees some diminution in the practical value of competition as a factor in the determination of prices. In an ever-increasing number of industries, the labourer finds himself opposed either to a single employer or to a ring. He may, by collective bargaining, secure standard conditions for himself as a labourer. As a consumer, he finds that the prices which he pays for commodities tend to be determined, not by supply and demand, not by competition or by collective bargaining, but by irresponsible individuals or companies who are out for maximum profits. So long as organised society provides no means for insuring that monopoly prices shall be fair and reasonable, the syndicalist has at hand a weapon of incalculable power. The opponent of syndicalism would be wise to recognise this fact.

1 Annals of the American Academy of Political and Social Science, July 1912, pp. I53-4. 
He should be ready with an alternative method of monopoly control. Otherwise, to many minds at least, essential facts will seem to be with the syndicalist. It is not necessary for the syndicalist to prove that monopolistic concerns have abused their power in the past, although it would be easy for him to do so. It is enough that there is an overwhelming probability against monopolistic power being exercised with due regard to all parties and the community in general. If the community, as organised in its political institutions, had adequately recognised in the past the responsibilities which arise out of the changing conditions of modern industry, many of the more serious difficulties of the present situation would not have arisen; and some amazing schemes which to-day are urged with more or less of plausibility would not have taken shape in the minds of men.

Finally, while the claims of the wage earner to the control and output of an industry receive an extravagant expression in the propaganda of syndicalism, those claims receive no adequate recognition under existing conditions. The worker does not get his fair share of the national dividend. Nor has he the interest in his work which he would have if he shared in its profits and had a voice in its control. The solution of the problem may possibly be found in some form of co-partnership or in a more or less qualified socialism. The supreme necessity is that it should be found. As a writer already quoted remarks, "By some means or other an industrial system must be devised which will give the workman a direct interest in 
his work, which will give him the maximum amount of control over his labour consistent with the maintenance of the maximum of efficiency of production. This is the great fact which syndicalism has emphasised." 1

1 Snowden, "Syndicalism and Socialism," p. 243. 


\section{CHAPTER III}

\section{THE STATE AND MONOPOLIES}

In the preceding chapter, I dissented from a proposed solution of the problems of modern capitalism. The social origin of private property, the qualified character of the claims of private property, the need for a more widely diffused ownership of industrial capital, and the reasons why every capitalist should be a producer and every worker an owner of industrial capitalthese are things to be dwelt upon by the student. They express much ; they imply much. But their interpretation in definite measures of reform can only be entrusted to deliberative assemblies which represent every class and interest of the community. The organised action of private individuals or associations may undoubtedly serve useful purposes. But those purposes should be regarded as ancillary to, not in substitution for, the action of the whole community as organised in its political, administrative and judicial institutions.

A like need is apparent when we pass from capitalism in general to the problems which arise in relation to monopolistic capitalism. In the present chapter, I approach the question of the ways in which State action should express itself in dealing with monopolistic capitalism. Several 
policies may be suggested. Most of them are reflected, though generally in a more or less partial form, in contemporary legislation. The more important of the policies are the following:

The limitation of the size of corporate business. Publicity.

The legislative regulation and administrative supervision of competition.

The limitation of profits.

The public regulation of prices.

Public competition.

Nationalisation.

The above policies may be classified on various principles. Some policies have a general application; others are dependent in a special degree upon the nature and conditions of particular monopolies. Publicity illustrates the former; public competition the latter. Again, some policies aim at preventing monopolies from coming into being; others aim at the regulation or control of a monopoly which is established. The limitation of corporate size illustrates the former; the public regulation of prices the latter. Finally, it is necessary to distinguish between three methods of State action which are necessary to carry out the policies above indicated. One method is a system of legal control under which an aggrieved party shall have a right to sue in the courts for any injury sustained. A second method is a system of administrative control by commissions or public officials exercising a right of investigation, supervision, and possibly of regulation and 
control, over monopolies in being or becoming. The third method is public ownership.

\section{No One Policy Adequate}

With respect to the various policies, there are, as I believe, two illusions which demand a preliminary notice. The first of these is that any one of them is adequate to the conditions which either exist to-day or are likely to exist in the near future. Many reformers, having once adopted a policy, dismiss any suggestion of limitations upon its value or scope with the hostility which the pious believer feels towards the pagan who challenges the all sufficiency of his religious faith. But the a priori probabilities are wholly against the claim of any one policy to solve the many problems of monopoly. For one thing, the economic social and political conditions of various countries are divergent. The variety of political conditions is perhaps the most obvious in its suggestion of the need for different forms of remedial legislation. A prudent statesmanship may entrust powers to public officials in one country which, in another country, would involve industrial chaos. In 1905, Chicago declared in favour of the municipalisation of street railways. The Mayor-elect invited Mr. Dalrymple, the manager of the Glasgow Municipal Tramways, to confer with him. Mr. Dalrymple arrived in the United States, an ardent advocate of public ownership. A few weeks' residence in Chicago, however, convinced him that he had failed to allow for the complete dissimilarity of conditions. 
He remained to repudiate what he had come to bless. ${ }^{1}$

But even in any one country, the law maker has to take into account the varying conditions and nature of different industries. An industry may be free trade or protected; it may supply a home or a foreign market; it may be peculiarly subject to, or peculiarly exempt from, the dangers of monopoly. In some industries, it is the producer who suffers. In other industries, it is the consumer or the employee. Again, while in some industries a system of legal control is adequate, in other industries a system of administrative supervision and control by public officials is imperative. Finally, in the case of many transport services, and services which vitally affect the health of the community, legal and administrative control may be less satisfactory than public ownership. As it is a wise maxim of statecraft that the punishment should fit the crime, so it is also a wise maxim of statecraft that the remedy should meet the disease. We do not want surgery if we can secure the end in view by preventive or curative medicine. We do not want to waste time over medicine, if surgery is imperative. The practical conclusion follows that a scheme of monopoly control must be flexible, comprehensive and adapted to varying industrial conditions.

I fear, however, that many people fail to recognise these elementary facts. Their zeal for a particular policy outruns their judgment. I am

1 I quote this incident from an admirable series of articles by Mr. Sydney Brooks, on "Some Aspects of Public Ownership," North American Review, vol. cxliv., p. 738. 
reminded of an itinerant vendor from whom, as a boy, I purchased a wonderful ointment. It was good for cuts, for bruises and for freckles. It was infallible for colds and indigestion-if applied in the right place! I scarcely dare name all the uses which it served. So there are writers, and even distinguished writers, and there are politicians, and even distinguished politicians, who come forward with some device which is to remedy the evils of all forms of monopoly. It is good for the steel trust and the transport combine. It is infallible for a monopoly in soap or candles. Even a sugar trust must be reduced to beneficence by its healing influence. I feel bound to say that I do not think that for to-day, or even for to-morrow, there is any such panacea.

\section{Complexity of Problem of Monopoly}

CONTROL

A second illusion, with respect to policies of monopoly control to which I have referred, also calls for some preliminary notice. It is that the choice between them, or the ideal combination of them, or the selection of the best means for giving effect to them, are matters about which we can afford to be dogmatic. There are three classes of people who may cavil at this statement. I wish to refer to these classes in order to clear the ground for further discussion in later chapters.

The first class consists of those who believe that the nationalisation of all forms of monopoly is immediately practicable and expedient. The class includes many socialists. It is naturally disposed 
to adopt a passive and complacent attitude toward monopolies because it sees in the monopoly that organisation of industry which most readily lends itself to the extension of the sphere of public ownership. I am unable to adopt this attitude. I shall indicate in a later chapter my reasons for regarding nationalisation as a policy for particular rather than universal application. ${ }^{1}$ In the meantime, it appears to me sufficient to say that the nationalisation of monopolies is not as yet supported by public opinion. Even if it were, there would remain the many and serious problems which arise in relation to the partial monopoly, or to the monopoly in becoming.

The second class consists of those who declare that present evils will in time work out their own salvation, and that government should leave private business alone. The class is the unconscious ally of syndicalism. In its zeal for a policy of absolute non-intervention, it affords a motive, if not a justification, for reform through revolutionary action by private associations.

The third class consists of those who profess an unbounded confidence in the efficacy of such legislation as the Sherman Act. While members of this class disown the reactionary doctrine that government should leave private business alone, they fight for the maintenance of the status quo with an obstinacy which is proof against all appeal to reason or justice. They may perhaps concede that the Sherman Act, and kindred legislation elsewhere, have quite failed to cope with the

1 Cf. infra Chapter VII. Cf. also Jethro Brown; " The Underlying Principles of Modern Legislation," Chapter VI. 
problems of monopoly. But the concession is accompanied by the suggestion of unimportant amendments which should convince no one who is not blinded by prejudice or self-interest. To people of this class, it appears a supreme object to secure a party in power which shall be pledged in substance to do either nothing at all or as little as possible. I use in this work the term conservative reformer. But the individual of the class in question has so much of conservatism, and so little of the desire for reform, that his claim to be called a reformer at all cannot be taken seriously.

I wish, at the outset of my argument, to dissociate myself from each of the classes mentioned. They propose easy solutions of a problem which I believe to be one of the most difficult of our time. The problem is under consideration in many countries ; there has been legislative action and administrative control; and the contributions of eminent writers, learned societies and official documents would fill a library. Yet, despite all our experience and thought, the best that can be said is that we are groping our way toward sound conclusions. Some useful data we have; and some principles seem to be clearly established. But the precise significance of the data is often doubtful; and the value of established principles is limited by the fact that we have to apply them, not to an ideal world, but to a world of actual facts around us. Many things that are desirable are not practicable; much that is practicable is not desirable. I believe that, if we are to proceed on right lines, we should begin 
with a recognition of the difficulties before us, their complicated character, and their manifold ramifications. When I have listened to some perorations on the subject of monopolies, I have been reminded of Sydney Smith's remark, "I only wish I could be as sure of anything as Tom Macaulay is of everything."

In the foregoing general observations, I assume that, subject to certain qualifications which I shall indicate later on, the maintenance of competitive industry is both desirable and practicable. The assumption requires a brief reference.

III. The Maintenance of Competitive INDUSTRY DESIRABLE

I hold that, at any rate for to-day and tomorrow, the weight of argument is with those who, while recognising that monopoly is the natural goal in some industries, believe that in most industries the maintenance of competitive industry is theoretically desirable. I have stated elsewhere the grounds upon which I base this belief. ${ }^{1}$ They admit of brief summary :

(I) Experience has proved that it is possible, by combination, co-operation or co-ordinated production, to effect a diminution of the wastes of competition. It is too often assumed that combination and competition are irreconcilable. In point of fact, combination is often a step to more effective competition. Even where it precludes competition in one form, it may evoke com-

1 "Underlying Principles of Modern Legislation "-chapter on "The Truth in Laissez-Faire : Competition." 
petition in another form. Firms which agree to sell a product at a certain price may still compete in quality of goods, or in facilities of service. Truth to tell, competition and combination, so far from being antithetical, are complementary factors in social progress. Everything depends upon the modes in which, and the conditions under which, these complementary factors operate. The problem of State control, in relation to both competition and combination, is not to destroy but to regulate in accordance with national purposes. When this is once realised, the argument against competition based upon the waste which it involves will have lost much of its force.

(2) Competition has many advantages to balance the objections to which it is open. The first of these is the regulation of the prices of commodities or services. As Professor J. B. Clark remarks, there are four parties who have a common interest in curbing monopolies-namely, the independent concern, the consumer, the employee and the farmer. "To protect the first of these four is to protect them all. If the rival producer cannot be crushed, the consumer, the labourer and the farmer are far better off. Moreover, as labourers and farmers are also consumers, they get double benefits." 1

(3) The second advantage of competition is the stimulus afforded to production. Competition among profit earners evokes effort, initiative and economy of administration; and to it we must attribute inventions and improvements in the processes of manufacture which have added 1 "The Control of Trusts," I9I2, pp. 8I-2. 
immensely to our material wealth and to the possibilities of civilised life. If necessity is the mother of invention, it is competition which has often created the necessity. A man does not know what he can do till he tries; but the difficulty is to get him to try. Competition makes him try. For the great majority of men, there is no stimulus of comparable value.

(4) The question of the desirability of retaining competitive industry involves a careful balancing of advantages and disadvantages. With regard to the wastes of competition, we have to reckon with the tendency towards its diminution, and with the danger of an even greater loss under a régime where competition should be inoperative or feeble. Arguments based on dishonesty in trade go to prove, not that competition is bad in itself, but that it requires careful regulation. Arguments based upon the inequalities of reward which an effective system of competition necessarily involves must be balanced against the gain which results to the community as a whole from maintaining the conditions of effective production. We must make our wealth before we can divide it. Some people are so obsessed by the inequalities of reward under competition that they would prefer a system in which everyone has bread and butter and nothing more, to a system under which everyone has bread and butter, but some have also golden syrup, or even, it may be, caviare. Personally, I believe that we are far more likely to be sure of having bread and butter for all under conditions where some people have more than others. I speak without prejudice to my conviction 
that those who have the something more should be, as far as practicable in a world of imperfections, the persons who win it in a fair and open field.

I make the foregoing observations, less for the ambitious purpose of justifying competitive industry, than for the purpose of defining my own attitude with regard to it. I believe that competitive industry has advantages which so far outweigh its disadvantages as to justify its retention where practicable. This must not be taken to mean an endorsement of the view that, because competition is a good thing, the State regulation of the conditions under which it is carried on should be strictly confined within the limits of a laissez-faire dispensation. The plea for so limited a regulation of competition is selfcontradictory. It appeals, in the name of competition, for the toleration of practices which are designed to bring about the elimination of competition. The thing to be desired is that competition shall be free in fact as well as in name; and in order that it should be free in fact it must be regulated in such a way as to prohibit unfair discriminations, and even, as far as practicable, the driving of prices below costs of production. On the latter point, Professor Clark well remarks, "The making of extra low prices to a rival's customers is a very effective method of getting those customers away from him. . . But this kind of competition is unworthy of the name, for it means merely a short spurt of low prices, followed by monopoly and permanent high prices. That is not our purpose, the people's purpose, in making the rules under which we allow competition to 
be carried on. If the object of competition be to secure the survival of those most fit to produce goods or to render services, then the case is exactly reversed; and this latter is the true view. To put the other man out of business, regardless of the effects on society-this is not, and never has been, the whole object of competition since cavemen stopped exploiting their fellows with stones and clubs. Since that time we have never had perfectly 'free' competition."1

\section{The Maintenance of Competitive INDUSTRY PRACTICABLE}

I have tried to explain briefly why I believe that the maintenance of competitive industry is theoretically desirable. I shall now state why I believe that the maintenance of competitive industry is, at any rate within limits, practicable. Some writers urge that the economic advantages of large scale business are such as to justify the assumption that all the more important industries are destined to pass under trust control. If this assumption be justified, while the maintenance of competitive industry might be theoretically desirable, it would be impracticable except at the price of preserving the less efficient at the expense of the more efficient form of industrial organisation.

No one can doubt that in most industries increasing facilities of transport and communication tell for an increasing size of business undertakings. Whether those facilities involve the trust as the ultimate form of industrial organisation

1 "The Control of Trusts," 1912, pp. 199-200. 
is another and more debatable question. An affirmative answer, however, is not justified by facts as revealed in the origins and history of existing trusts. A large number of trusts have owed their formation to the credulity of the investing public. Dazzled by the profits of particular trusts, investors have argued from the particular to the general, have assumed that a trust necessarily means efficiency, and have fallen an easy prey to the speculative manipulations of the promoter. A trust has been formed simply for the purpose of floating new issue of stock on the market and selling it at an inflated price. The amount of capital subscribed by shareholders has served to indicate, not a reasonable estimate of the earning capacity of the business as a going concern, but the extravagant expectations of a credulous public.

Even where trusts have proved a profitable investment to the shareholder, the result has often been due, not to the economic efficiency of large scale business, but to monopoly power. The independent rival has been "clubbed" out of existence by unfair methods of competition; and, with an elimination of competitors, the trust has been enabled to exploit the producer, the employee, or the consumer. While the exploitation has been subject to limitations owing to the fear of bringing new competitors into existence, or to the danger of squeezing producers out of existence, or to the possibility of arousing the hostility of organised labour, or to the certainty of reducing the demand if prices to the consumer are fixed too high, it has yet often enabled a trust to survive 
and pay handsome dividends. But a trust which survives, not because it is a more efficient means of production or distribution than the independent concerns which it destroys or absorbs, but because it exploits one class or another of the community, is a bad national investment. It is, moreover, a legitimate object of public regulation and control. Assuming such regulation and control-and they are being evolved under the pressure of necessitythe tendency toward trust formation will receive an emphatic check.

Those who maintain that all industry is destined to be organised in the trust form are apt to overlook the disadvantages to which the big business is subject. Those disadvantages, while frequently exaggerated by writers who advocate the desirability of preserving competitive industry at all costs, are indispensable and must not be ignored. The spirit of bureaucracy, the relative absence of that appeal to individual enterprise which exists in the case of independent concerns, the need for exceptional skill in the management, and the difficulties of reconciling with highly centralised administration the educative discipline of decentralised business-each and all of these are factors which have to be taken into consideration when casting the horoscope of industrial organisation in the future.

The foregoing disadvantages are not likely to receive adequate recognition so long as trusts can club competitors by unfair methods of competition, or prey upon the producer, employee or consumer. But they will become apparent just in proportion as the State, through one means or 
another, succeeds in preventing monopoly power from being acquired or maintained save on a basis of superior efficiency. Even under existing conditions, the limitation upon the tendency to concentrated capitalism has told for the persistent survival of the small business in many fields of industry. The fact has not escaped the notice of writers whose advocacy of nationalised industry might predispose them to ignore it. As an eminent socialist remarks, "All these small businesses in agriculture, the mechanical trades, mining, retail trade, the arts and professions survive because of certain features in the materials or processes involved which give importance to those personal qualities of skill, care, judgment and character incapable of being evoked, controlled, and applied effectively under the routine economy of the large business." 1

Professor Ely, in his discussion of the doctrine that competition is self-annihilating, arrives at the conclusion which is implicit in the passage cited. He points out that bargains may be "picked up" in a small way, as well as in a large way, that sooner or later the point of maximum effectiveness is reached, that railway freights (provided the railways do not act in defiance of law) soon reach a point where no further advantage is to be gained, and that this point is in fact reached with comparatively small orders. With regard to the view that "fixed charges" decrease relatively as a business increases, the author points out that even here a point of maximum efficiency is reached sooner or later, and that new charges emerge as

'J. A. Hobson, "The Evolution of Modern Capitalism," p. I33. 
the business grows. "A superintendent who can be had for fifteen hundred dollars a year has to give way to one who can command ten thousand dollars, fifteen thousand dollars, or even more. The bookkeeping has finally to be reorganised and made more expensive; new buildings must be constructed; expenses of an entirely new sort appear. A large item in the expense account of many huge establishments consists in an outlay to prevent being cheated and robbed, or to keep in order immense forces of employees. Thus, in the case of some vast businesses, we hear a great deal about the employment of 'spotters' and private detectives." 1 The author concludes, "So far as we now see, we have a large field belonging to monopoly; but outside of this field we have another in which, under right conditions, competition is a permanent social force." 2

With this conclusion I concur. While it would be premature to dogmatise as to the future, I can see nothing in available data to justify the assumption that the whole world of industry is destined to organisation in the trust form. On the contrary, I believe that the greater number of industries will continue to be carried on by more or less independent concerns. In this connection, one significant tendency in Australia deserves mention. The increasing rate of wage, and the increasing difficulty of maintaining the standard of labour, have given a new encouragement in certain industries to the small producer. In these industries, the independent producer, by

1 Ely, "Monopolies and Trusts," pp. 165-6.

Ibid., p. 79. 
the labour of himself and his family, supplemented it may be by the assistance of hired labour, is more than able to hold his own.

In the foregoing remarks, I have been mainly concerned to state my reasons for dissenting from the proposition that there exists throughout the whole field of industry a natural and irresistible tendency toward organisation in the trust form. But even assuming, as I believe, that this proposition is unwarranted, other forms of concentrated capitalism, such as the combine, pool or cartel, may go far to restrict competition and to deprive society of the advantages which it affords. Mr. Van Hise contends that, in the United States, competition, as a means of controlling prices, has been a lamentable failure, and that prices are fixed even in the retail trade, " the last stronghold of competition," by agreement formal or informal. ${ }^{1}$ Three observations suggest themselves (I) The conclusion of the learned author, if true in the United States, is far from true in most other countries. (2) The conclusion must be read along with the author's disclaimer of any intention to imply either that competition has not been a most useful economic force in the past, or that it will not continue to be a useful force. Competition, he urges, has proved a powerful stimulus to effort, has been potent under some conditions in improving quality, has limited margins within "monopoly prices," and has been dominant in improving service. "From the smallest firm to the greatest corporation there has been an increase rather than a decrease in the power of competition

1 "Concentration and Control," pp. 79-88. 
in improvement of service." I (3) I believe that the relative failure of competition to regulate the price of commodities or services in the United States is due in a very large measure to the fact that industrial progress in America has outgrown the system of State regulation of industry to a greater extent than in other countries. For various reasons, the brains of the American community have gone into business rather than politics. Moreover, the very magnitude and resources of the country, its protective tariff, and its federal form of government, have placed peculiar difficulties in the way of public regulation of industrial and commercial enterprise. It may well be that the chief value of American experience for other countries is to show that statesmanship should seek to prevent as well as to ameliorate - to deal with evils as they arise without waiting for them to reach a stage when any remedy may involve far-reaching social and industrial dislocation. Speaking at any rate with reference to political communities within the Empire, I believe that, while in some industries monopoly may be regarded as natural if not inevitable, the acquirement of monopoly power in most industries may be prevented if the State realises its responsibilities. I propose to consider the nature of those responsibilities in succeeding chapters.

1 “Concentration and Control," p. 88. 


\section{CHAPTER IV}

THE LIMITATION OF CORPORATE SIZE

In the preceding chapter I referred to the division of policies according as their paramount aim is prevention or one of regulation and control. One class seeks to preserve competitive industry; the other class seeks to ensure that a monopoly shall not use its power as a means of exploiting the producer, employee or consumer. On examination, it will be found that this classification is somewhat arbitrary. A policy which seeks to prevent monopolies from coming into being may indirectly act as a check upon the abuse of power by a monopoly which is established. A policy which seeks to regulate or control established monopolies may indirectly deter other monopolies from coming into being. The division between the two classes is simply one of paramount aim. In the present chapter I propose to deal with one of the policies of prevention-the limitation of corporate size.

\section{The Policy Explained}

According to the advocates of the policy under consideration, a limitation should be imposed upon the size of corporations so as to preclude any one corporation from acquiring a dominating 
control. "There has never been a time," writes Mr. Howland, "when people were not more exercised over the conditions oppressing them than over the causes out of which the conditions had their growth. Everyone is hostile to the effects of monopoly; few will make the effort to penetrate to its cause. Our measures of relief must go straight at the cause. To prevent monopoly we must restrain the consolidation of corporate wealth by limiting corporate size; we should altogether forbid intercorporate stockholdings, and should impose carefully chosen limitations upon the amount of capitalisation and the holding of corporate assets. The limitation upon capitalisation will depend upon the extent of the national market; if no corporation is allowed to grow big enough to fill this market, some competition at least within the nation is restored." I

Professor J. B. Clark adopts a view not dissimilar from that expressed by Mr. Howland. "It is to be hoped and expected," he declares, " that corporations doing inter-state business will be required to act under either a federal licence or a federal charter, and that an industrial commission of some kind will decide who shall receive such charters. In performing this duty, the commission will be the supreme protector of the public, and if it is able and faithful, it will never license a company which is in possession of the whole field of its special industry. It will impose on every corporation a burden of proof - first,

1 "Monopolies: the Cause and the Remedy," Columbia Law Review, February I9I0, p. 106. 
that it does not have the whole field; secondly, that rivals maintain themselves by their own excellence and are not tolerated as a blind for the public; thirdly, that there are enough of them to affect the standards of price in the whole industry; and fourthly, that the way is so open for the entrance of more that prices cannot become extortionate." 1

President Woodrow Wilson writes, "I take my stand absolutely, where every progressive ought to take his stand, on the proposition that private monopoly is indefensible and intolerable."

In estimating the importance we should attach to the opinions of American writers, we must remember that they have American conditions in view. Those conditions are in some respects peculiar. In the first place, if one may judge from available data, there is more "graft" than exists, for example, in communities within the Empire. Hence an attitude of scepticism with respect to the possibilities of effective regulation of monopolies by public authorities, and a disposition to conserve competitive industry at all costs. In the second place, capital is abundant in the United States; and the capitalist is unusually speculative and gifted with an exceptional initiative. Within the last few years, wrote Attorney-General Knox in I903, the embarkation of new capital in competition. with the industries supposed to be controlled by the trusts has probably equalled the total capital of the trusts.

1 "Annals of the American Academy of Social and Political Science," July I9I2, pp. 65-6.

2 "The New Freedom," I9I3, p. I 72.

6 
Such facts not unnaturally affect the views of American writers with respect to the area within which competitive industry may be conserved. The writer just quoted remarks, "In my judgment, a monopoly in any industry would be impossible in this country, where money is abundant and cheap, and in the hands or within the reach of keen and capable men, if competition were assured of a fair and open field, and protected against unfair, artificial and discriminating practices." " In the third place, the American States extend over an immense area and include a vast population. The fact has a bearing upon the question whether what is called the business unit-i.e. the size necessary to secure the maximum of economic efficiency-will be reached in any industry before monopoly control is gained. Most American writers who urge a limitation upon the size of corporate business start from an assumption that America is too big a country to admit of a business acquiring monopoly control except by passing the limit of efficiency and getting into the region of clumsiness and unwieldiness. ${ }^{2}$

\section{Expediency of Policy}

The peculiarities of conditions to which I have referred discount the value of the opinions of American writers when the milieu is changed. In my own opinion, so far at any rate as most countries are concerned, the policy of limiting the size of

1 Quoted, Ripley, “Trusts, Pools and Combinations," p. 65.

2 Cf. Woodrow Wilson, "The New Freedom," rgr 3, pp. 172-3. 
corporate business, as distinct from the policies of prevention to which I shall refer in succeeding chapters, is inexpedient.

It is necessary to begin by recognising the possibilities of large scale business. The terms "trust" and the "combine" have an evil sound. They suggest an octopus whose long and relentless arms encircle the producer, the employee and the consumer in the grip of an all-absorbing greed. Nevertheless, combination has very great advantages. In its more elementary forms, it means the economies in purchase, freights and fixed charges. It means also the power to secure the best brains, the latest machinery, the utilisation of waste products, and the relative diminution of the wastes of competition. Even where combination involves monopoly, it may have compensating gains. It tends to mitigate the evils of over-production and crises, and to secure a stability of industry and a relative permanence of employment. Combination is, in fact, a natural and inevitable step in the evolution of modern business. Private concerns are driven to combine by pressure both from within the State and from without. An American magnate when asked the reason for joining a particular combine said, "We had to do it or bust." "The problems connected with syndicates," remarked recently the Prussian Minister of Commerce, " are difficult to solve, but to overthrow syndicates would destroy the ability of our country to compete abroad." The experience of Germany, in this matter, is significant. The German is in the vanguard of commercial progress; yet, combination in Germany, instead 


\section{THE LIMITATION OF CORPORATE SIZE}

of being the subject of abuse or attack, is favourably regarded by all classes. "Opposition to the trust in Germany," writes Dr. Ernest von Halle, " has nowhere been made a plank of political platforms or been used in election contests. Among officials, scientists and lawyers cartels are not considered unwholesome or objectionable per se. The Supreme Court of the Empire in March 1898 officially recognised the economic justification of combinations and their right to legal protection unless they use unlawful methods of cheating competitors who decline to join them." 1

Advocates who urge a limitation upon the size of corporate business are of course aware of the advantages of large scale organisation: But they appear to be of the opinion either that the ideal business unit is reached before monopoly control is gained, or else that, where the alternative lies between the big business and competitive industry, the latter is to be preferred. Both these opinions require examination.

Professor Clark maintains that " centralisation can go far enough to give us a maximum of productivity without destroying freedom of individual action, competition and the right of contract." 2 But, as I have already pointed out, he is generalising from American conditions. Whatever may be said of those conditions, experience goes to show that, in most other countries at any rate, a monopoly power may be gained

1 Quoted, "Annals of the American Academy of Political and Social Science," July I9I2, p. I6I.

2 J. B. and J. M. Clark, "The Control of Trusts," p. 22. 
and held on the sole basis of a superior economic efficiency of the large scale organisation. The trend of modern progress is in the direction of adding to the number of industries in which such a monopoly is possible. Two reasons for this conclusion deserve special mention. The first is that man's increasing control over natural forces is constantly adding to the resources and possibilities of collective action. The second is man's adaptability to new conditions. These reasons, though interrelated, require to be distinguished. Discoveries and inventions tend to make possible an ever-increasing concentration of business; and the mind of man is at work seeking to make that concentration increasingly efficient. A single example will serve to illustrate the latter statement. In some trusts to-day, the output and costs of production in different plants are carefully recorded, and the salary of employees enhanced on proof of exceptional efficiency. This is not competitive industry as ordinarily understood. But the arrangement goes to secure many of the advantages of competitive industry. Competition exists in the wide sense of an active rivalry between those who are engaged in the discharge of like economic functions. For the foregoing reasons I cannot agree with those who assume that the advantages of large scale business can be secured before monopoly control is gained. On the contrary, the assumption appears to me to be refuted, so far as a few industries are concerned by established facts, and so far as some other industries are concerned by existing tendencies. 


\section{THE LIMITATION OF CORPORATE SIZE}

I turn to the opinion that where the alternative lies between the big business and competitive industry the latter is to be preferred. Advocates of the policy of limiting the size of corporate undertakings, while professing a belief in the big business, define such business, not by reference to the business unit, but by reference to that degree of concentration which is consistent with the maintenance of competitive industry. The last mentioned is to be preserved at all costs. The grounds of this conclusion cannot be fully examined without discussing the practicability of certain policies for the control of established monopolies, which will be the subject of consideration in later chapters - for example, nationalisation and the public regulation of prices. But I may remark here that a prima-facie case against the expediency of preserving competitive industry by limiting the size of business concerns is made out by the mere fact that a monopoly may be gained and held by fair means. Where a monopoly is so gained and held, where it is the result of a superiority of output, low prices or a general efficiency of management, its dissolution implies a premium on inefficiency, a recurrence to the waste of competition, and a disregard of the advantage of large scale organisation both in preventing over-production and crises and in securing a relative permanence of employment.

\section{Practicability of Policy}

The policy of limiting the size of corporate business may be questioned on other grounds 
than those stated. I must confess that there appears to me to be something illogical in saying to a private business concern, "You shall compete, but you shall not compete too successfully. If you are so far successful as to extinguish or absorb your competitors, you shall be dissolved." I have often felt a sympathy for the policeman who has to use his baton with just enough skill to impress the insurgent's mind without inflicting excessive damage on his skull. The industrial concern which must compete, but must not compete too successfully, has to be efficient but not too efficient! Further, the limitation of corporate size as a means of preventing monopoly control could not be effected by general legislation. The amount of business which the policy would concede to a particular company must vary with the nature of different industries. An administrative commission would be necessary; and the task imposed upon that commission would be one of extreme difficulty. Such difficulties, and the disadvantages previously stated, might not afford an adequate justification for rejecting the policy of limiting corporate size if we could only be sure that the effective carrying out of the policy would solve the problem of monopoly. But it is just here where we come upon a difficulty to which I shall have to refer at length in a later chapter. How is the law, or an administrative commission, to compel private concerns to compete if they prefer to combine? Parliament may impose a limit upon the size of corporate undertakings. A Court or a Commission may dissolve a trust. But neither Parliament nor a judicial tribunal 
can prevent a secret understanding between nominally competing concerns.

\section{CONCLUSION}

For the foregoing reasons I am not disposed to attach much importance to the policy of prohibiting monopolies by imposing an arbitrary limit upon the size of corporate enterprise. I believe, however, in the policy of prohibiting unfair competition. The fundamental difference between the policies is that the latter, by securing a fair field and no favour, does not attack the big business per se, but imposes upon the big business the burden of proving that its size really represents increased efficiency. Even in America, where special reasons may be urged in justification of the policy of limiting corporate size, there are eminent writers whose judgment on the present point coincides with my own. "The ideal condition, to my thinking," declares Professor Wyman, of Harvard, "is to have monopoly where that is the more effective form, and competition where that is the natural thing. To that end, the law should do its best to see to it that there shall be an open market in which that type which is the economically advantageous shall survive. . . . It seems clear that in certain business you cannot have the highest degree of industrial efficiency without the greatest possible concentration. Where monopoly is thus natural, I am prepared to argue that there is necessarily something good in it, which can be turned to the common advantage, if its conduct should be efficiently 
regulated. Indeed, I am not afraid to say that efficient regulation is the real solution cf the trust problem." ' What in my own opinion constitutes "efficient regulation," and how it is to be brought about, are questions to which I shall return in later chapters.

Before passing from the subject of the present chapter, I feel that I ought to say a word in justice to a writer whom I have quoted as an eminent advocate of the policy of limiting corporate size. I allude to Professor J. B. Clark. When the learned author comes to deal with the objection that in breaking up the trusts we may be smashing the engines of progress and efficiency, he does not expressly deny the validity of the objection. He urges that it can neither be proved nor absolutely disproved with the limited knowledge we now possess. "Experience alone can give a final answer." 2 This reticence is not consistent with statements which the author makes in the earlier part of his work. Moreover, it appears to me to involve the conclusion that we should allow the big business to exist, and simply insist that it should demonstrate its fitness to survive by defeating rivals by fair methods of competition. If we impose an arbitrary limit upon corporate size, we preclude the possibility of that experimentation which Professor Clark would presumably recognise as desirable.

1 "Annals of the American Academy of Social and Political Science," July I9I2, pp. 67-8.

2 "The Control of Trusts," I912, pp. 196-7. 


\section{CHAPTER V}

\section{PUBLICITY}

IN the preceding chapter, I urged that the State should seek to prevent a business from acquiring monopoly power save on the basis of economic efficiency. For this purpose, the State should insist upon a reasonable publicity of the affairs and methods of the big business, and it should also prohibit unfair competition. In the present chapter, I propose to deal with the subject of publicity.

As I shall show later on, an exclusive or exaggerated reliance upon publicity would be disastrous. Within limits, however, the policy has many advantages. (I) The pressure of public opinion, and the fear of legislative action, will operate more effectively as a means of safeguarding the producer, the competitor, the employee and the consumer, where the actual profits of the large concern are known or knowable. "Light is the best policeman." (2) The disclosure of high profits stimulates competition. (3) A salutary check may be placed upon the present practice of forming a trust or combine in order to float shares of stock and sell them to the public at artificial prices. According to Mr. Meade, the class in America most seriously injured by the results of 
speculative promotion is the class of investors. ${ }^{1}$ (4) The public would acquire useful information with respect to the need for public control and the means to be adopted in relation to it. (5) The conditions of modern business, more especially the veil of secrecy which corporate undertakings throw over their methods and results, have dulled the conscience of the modern business man. The trust magnate, like other human beings, is often unconscious of the ethically questionable character of his actions until he is confronted by the danger of being found out. Effective machinery for finding him out would not only bring into operation the forces of public opinion, but would also give a new vitality to the conscience within.

Some business men maintain that the community has no right to call upon a private corporation to disclose its profits. The view is indefensible in the case of monopolies (in being or becoming). If the community is to safeguard the producer, the employee or the consumer, it must act with knowledge of the facts. It must know, inter alia, what the profits of the monopoly are. Undoubtedly, the right of the community to compel disclosure should be exercised with discretion. Secret processes of manufacture need not to be divulged; every care should be taken to avoid doing anything which might prejudice a company in its competition in foreign markets; and, generally, both the nature of the information required and the degree of publicity given to it should be determined with reasonable regard to private interests. But when the owners of a 1 "Trust Finance," p. 356. 
business, which is either a monopoly or in danger of becoming one, contend that the community has no right to demand an adequate disclosure of their profits, they are simply playing into the hands of the revolutionary. They could not adopt an attitude more calculated to give a colour of justification to the confiscatory propaganda of the syndicalist.

Assuming the right of the community to insist upon reasonable publicity, the question arises as to the best machinery for effecting this end. One means is the conduct of investigations by Royal Commissions of Inquiry. In each of the Australian States, the prerogative of the Crown to issue Commissions of Inquiry has been supplemented by statutes which empower such Commissions to compel witnesses to attend, to give evidence on oath, and to produce relevant documents. The Commonwealth Parliament in Igr2 passed a drastic Act with the object of amplifying the powers of Royal Commissions, and of facili. tating their investigations by imposing heavy penalties upon the recalcitrant witness. "The principle of the Act," remarks a judicial writer, "is first to substitute the widest discretion in the executive government and in the commission for the limited powers under the earlier law in order to avoid the interruption of inquiries by long-drawn-out legal proceedings to test the extent of the commission's powers ; secondly, to sanction the law by penalties of so severe a kind as to deter even wealthy interests from opposing the course of inquiries. No doubt the powers are liable to abuse, and the severity of the penalties is calcu- 
lated to deter people from taking risks even where the law is probably being exceeded; and commissioners may think that any strong criticism is wilful contempt. But the rights of legal objection were also liable to abuse; ingenious minds and ample powers together could furnish a series of interruptions which would suspend indefinitely the course of the inquiry. The Act is one of the many modern indications of the belief that a government resting upon responsibility to the people is a better interpreter of 'social justice' than are the courts of law." 1

In December, I9I3, the Privy Council declared that the above Act, in so far as it purported to confer upon Royal Commissions the power to compel witnesses to give evidence, was in excess of the constitutional authority of the Commonwealth Legislature. The decision has been hailed in many quarters as a triumph for " the liberty of the subject" and "the rights of the States." Its probable effect, however, will be to strengthen the hands of the Labour Party, which is pledged to several important amendments of the Constitution designed to enlarge the ambit of the Commonwealth authority.

In addition to the above-mentioned statutes, two other statutes of the Commonwealth Parliament deserve brief reference. The powers of investigation conferred upon Royal Commissions by the Act of I9I2 are also conferred upon the Inter-State Commission by an Act which was passed in the same session. The Acts for the

1 Professor Harrison Moore, in The Columbia Law Review, June 1913, pp. 509-10. 
Preservation of the Australian Industries, I906-Io, based on the Sherman Act and especially directed against the abuses of monopolies in being or becoming, empower the Comptroller General of Customs to summon any witness, whom he believes to be capable of giving information in relation to an alleged offence under the Act, to answer questions or to produce documents. The witness so summoned is not exempt from the duty to answer any question or to produce any document on the ground of self-incrimination; but his answer is not admissible in evidence against him in any civil or criminal proceeding other than a proceeding for an offence under the Act.

The policy of publicity, as a means of controlling industrial combinations, is also exemplified in the Combines Investigation Act of the Canadian Parliament, passed in I9ro. An Act of 1907 had already dealt with employees. The Act of Igro applies to producers and consumers. It provides that any six persons, being British subjects and resident in Canada, may make a declaration to a judge of the High Court that a combine exists, and that prices have thereby been enhanced, or that competition has been restricted, to their detriment. The judge must order a Board of Investigation if it appears (I) that a combine exists which is either injurious to trade or operates to the detriment of producers or consumers, (2) that the public interest warrants an investigation. The Board is appointed by the Government. It must consist of three members-a chairman, a representative of the applicants, and a representative of the alleged combine. 
The chairman must be a judge of one of the courts of record. He is selected by the above-mentioned representatives, or, if these are unable to agree, by the Government. The Board so constituted may summon and examine witnesses under oath; and it may require the production of any books, papers or other documents which it deems necessary for the purposes of the investigation. The findings of the Board are published in the Government Gazette. While they may be made the basis of Governmental action in the form of a reduction of Customs duties, revocation of patents, or a criminal prosecution, the chief significance of the Combines Investigation Act for present purposes consists in the means which it affords of maintaining the standard of business morality and of informing the public with respect to such conditions as may call for legislative or administrative action.

The adequacy of Australian or Canadian legislation, as a means of securing a reasonable publicity of the affairs of large business undertakings, remains to be proved. Personally, I regard the legislation as incomplete. Canada provides means for the creation of a tribunal from time to time. Australia has a permanent tribunal ; but its value for the purposes under consideration is slight, owing to the multiplicity of the functions which it has to discharge. In view of the rapid development in the number of big business undertakings, I believe that a clear necessity exists for a permanent Commission specially charged to supervise such undertakings. The Commission should be empowered to demand such information as it 
may deem necessary, and to publish such information as it deems advisable. The Commission should also be entrusted with further powers of which the nature and scope will be the subject of consideration in later chapters.

In the foregoing remarks, I have dwelt upon publicity in so far as it bears upon the problem of monopoly. It would be beyond my province to deal with the subject of Company Law as such. No student of that subject, however, will need to be informed that the existing conditions of secrecy, under which in most communities a company can conduct its affairs, are indefensible from other points of view than those considered in the present chapter. On the whole subject, I refer the reader to the recent work of Professor Haney on "Business Organisation and Combination." 


\section{CHAPTER VI}

LEGAL REGULATION AND ADMINISTRATIVE SUPERVISION OF COMPETITION

\section{INTRODUCTORY}

THE importance attached to any particular policy, whether for the prevention of monopolies or for their regulation and control, varies with the diagnosis of trust origins. The advocate of publicity dwells upon the conditions of secrecy under which the large business is conducted. President Woodrow Wilson, in company with many other writers, emphasises the need for public control over the conditions of competition. The "giants" will disappear if the State secures a fair field to the "pigmies." "I have been told by a great many men that the idea I have, that by restoring competition you can restore industrial freedom, is based upon a failure to observe the actual happenings of the last decades in this country; because, they say, it is just free competition that has made it possible for the big to crush the little. I reply, it is not free competition that has done that; it is illicit competition. It is competition of the kind that the law ought to stop, and can stop-this crushing of the little man." 1

As I have remarked in an earlier chapter, it is

1 "The New Freedom," Iو13, p. I77. 
impossible to maintain that the trust only comes into being by resort to predatory practices. The more important of existing trusts, however, have undoubtedly developed in this way. They are based, as President Wilson remarks, not upon efficiency but upon power. If the State can moralise the conditions of competition, it will (I) prevent many monopolies from coming into being, (2) restore competition in some fields which are now subject to monopoly control, and (3) check the abuse of power by a monopoly which has come to stay. In the present chapter, I am concerned with the first and second of these advantages. How are they to be secured?

I have previously referred to varieties in the form of competition according as it tends to regulate prices, to improve the quality of goods, or to secure a maximum efficiency of service. Competition may also be residual, potential or collateral. Residual competition is the survival of competition in cases where capitalistic concentration still leaves some rivals in the field. The term "potential competition" expresses the restraining influence which results from the fear of bringing new rivals into existence. Collateral competition is the competition of some substitutable commodity or service. Legal regulation and administrative supervision should aim at the maintenance of competition, whether it be residual, actual or potential, and whether it relate to price, quality or efficiency of service, so far as these various forms of competition are serviceable means to ensuring that concentrated capitalism shall only survive on a basis of superior efficiency. 
In its primary aspect, the legislative regulation of competition, as a means of effecting the prevention of monopolies, means the prohibition of predatory competition. Some people contend that modern competition is necessarily predatory; and that the so-called predatory trust is merely trying to do what every business firm is trying to doi.e. to get as much trade as it can. But there is a real distinction between the ordinary trade policy of increasing a business by the superiority of output, the cheapness of price, facilities of service, etc., and an endeavour to crush rivals out of existence by certain devices of which the general character is well expressed in a dictum of the Supreme Court of the United States in the Standard Oil Case, IgII. The dictum refers to "those contracts or acts which have not been entered into or performed with a legitimate purpose of reasonably forwarding personal interest and developing trade, but, on the contrary, are of such a nature as to give rise to the inference or presumption that they have been entered into or done with the intent to do wrong to the general public and to limit the rights of individuals." " The contracts or acts to which this dictum refers cover a wide range of business transactions. The more typical of them are referred to in a Bill which was introduced into the Victorian Legislative Council by Mr. Drysdale Brown in I9I3. The Bill penalises any combination which agrees to refuse to sell goods to others for cash either (I) absolutely, or (2) except at a price so high as to justify a reasonable belief that the seller desires to

$$
122 \text { I U.S., p. } 5^{8} .
$$


discriminate against an actual or intending buyer as compared with other buyers, or (3) except upon terms or conditions which express or imply that the buyer shall not buy from anyone but the seller or parties indicated by him.

\section{Australian Commonwealth Legislation}

The consolidated Acts for the Preservation of Australian Industries, based on the Sherman Act, are an attempt to codify the law relating to the prohibition of predatory competition. The following sections, which I venture to abbreviate, deserve special consideration.

Sect. 4 (I). Any person is guilty of an offence who contracts, or participates in any combination, in relation to trade or commerce with other countries or among the States,

(a) In restraint of or with intent to restrain trade or commerce, or

(b) To the injury of or with intent to injure any Australian industry by means of unfair competition, having due regard to the interests of producers, workers, and consumers.

Penalty, $£ 500$; or in case of continuing offence $£ 500$ for each day during which offence continues.

(2) Contracts in contravention of this Section shall be illegal and void.

(3) It shall be a defence to a proceeding under paragraph (a) of Sub-Section I of this 
Section, if the person proceeded against proves

(a) That there was no detriment to the public, and

(b) That the restraint of trade or commerce was not unreasonable.

Sect. 6 (I). For the purposes of Section 4, unfair competition means competition which is unfair in the circumstances; and in the following cases competition shall be deemed prima facie unfair :

(a) If the defendant is a Commercial Trust (defined in Section 3).

(b) If competition would probably, or does in part, result in inadequate remuneration for labour.

(c) If the competition disorganises Australian industry or throws workers out of employment.

(d) If the defendant grants a rebate, etc., on condition of exclusive dealing. also Section $7 a$, Sub-Section 3.)

(Cf.

(2) In determining whether the competition is unfair, regard shall be had to the efficiency of the management, processes, plant and machinery.

Sect. 7. Any person who monopolises, or attempts to monopolise, any part of the trade or commerce with other countries or among the States is guilty of an indictable offence.

$7 b$. Any person is guilty of an offence who, in relation to other than Intra-State trade, refuses absolutely or only upon dis- 
advantageous conditions to sell goods or supply services to another person on the ground that such other person-

(a) deals with third parties;

(b) is not a member of the Commercial Trust.

Sect: II. Persons injured by reasons of acts done in contravention of the above sections may recover treble damages.

Sect. I $5 b$. If the Comptroller-General believes that an offence has been committed, he may request any person whom he believes to be capable of giving information in relation to the alleged offence to answer questions or produce documents.

The above sections indicate the general purport of the Acts. Broadly speaking, the objects are twofold; first, to ensure that a monopoly shall only be acquired by fair methods; second, to restrain a monopolistic power, when once acquired, from predatory attempts to keep the market to itself. Section 7 appears to go further. But I think we may assume that the Australian courts will interpret the word "monopolise" as equivalent to the exercise of a monopolistic control in an unreasonable or repressive manner. A literal interpretation would make the exclusive ownership of the sources of supply an indictable offence: The Supreme Court of the United States, in the Standard Oil and Tobacco cases, when called upon to interpret a similar provision in the Sherman Act, affirmed that the "standard of reason which had been applied at the common law in dealing with the subjects of the character embraced in the 
Statute was intended to be the measure used for the purpose of determining whether in a given case a particular Act had or had not brought about the wrong against which the Statute provided." In any case, Section 7 does not appear to be of much practical importance. The word "monopoly" in the Statute can hardly apply to anything less than an absolutely exclusive control. Existing trusts or combines are content with such a degree of control as will enable them to determine prices. This degree of control is obtainable long before the acquisition of monopoly in the sense indicated.

\section{Critical Examination}

The value of the Acts for the Preservation of Australian Industries is qualified by certain limitations and defects which I now propose to consider in order to illustrate, in more detail, the character of the policy of monopoly prevention which is the subject of the present chapter.

(I) The first limitation upon the value of the Acts arises from the distribution of governmental powers between the Commonwealth and the States. The Acts, in respect of which proceedings may be taken, must be Acts in relation to trade or commerce with other countries or among the States. The dealings of a corporation within the State in which it is incorporated are beyond the scope of the Act. The monopoly, or the restraint of trade, or the unfair competition, must be Inter-State, not Intra-State. What this means in practice is illustrated in a Memorandum of the Hon. P. McM. Glynn, then Attorney-General 
in the Liberal Administration. "Twenty-nine or thirty out of thirty-three cases that have been considered in this department are, according to the judgment in Huddart Parker \& Co. $v$ Moorhead, within the jurisdiction of the States only; but the most important are Inter-State; and none (affecting more than one State) can be completely dealt with without the co-operation of the States or an amendment of the Constitution. In some cases, the same combination monopolises practically the whole of the State trade, and restrains, if it does not monopolise, the Inter-State trade, in respect of particular commodities or services."

How far the constitutional limitations just considered call for enlargement of the area of federal competence is a question about which Australian political parties are at present in acute antagonism. While both parties agree that some amendment of the Constitution is desirable, the Labour Party is pledged to drastic amendments of which the general effect, in the expressed opinion of the Liberal Party, would be the virtual extinction of the several States as political entities. One reason for the wide divergence of opinion which exists is to be found in a difference between the structure of the Federal and State Parliaments. The Federal Upper House is a democratic body; the Upper Houses of the several States are either nominee chambers or else elected on a restricted franchise. It is a very unfortunate fact for the future of the federal system in Australia that the attitude of political parties towards proposals to enlarge the area of federal competence should be affected to a large extent by reference to a con- 
sideration which is historical and accidental. The plain truth is that the Australian Labour Party is more concerned to realise a particular programme in legislation than to do justice to legitimate claims of the several States to self-government. On the other hand, the Liberal electorate, recognising the power of the States' Upper Houses to qualify or reject legislation which it considers socialistic in tendency, is disposed to reject proposals for the enlargement of federal competence however legitimate those proposals may be from the point of view of an ideal distribution of power between a Federation and the States.

It will be apparent from the foregoing remarks that a discussion of the case for an enlargement of the area of federal competence involves considerations which are beyond the scope of the present work. The discussion would also involve a careful examination of the exact extent of the existing area-a subject about which there is much difference of opinion among constitutional authorities. For the purpose of the present work, I assume that a division of powers over corporations as between Commonwealth and States is theoretically justifiable, and I limit myself to a brief statement of the more important desiderata if the system of divided control is to prove approximately effective.

The first desideratum is that the delimitation of powers should be clearly marked. There must be, to quote the felicitous phrase of Mr. Bryan, "no twilight zone between the nation and the State in which exploiting interests can take refuge from both." The second desideratum is that the 
control should rest with the authority most competent to deal with the particular subject matter. As I have already shown, this desideratum in practical politics involves a consideration of the structure of Commonwealth and State Parliaments. But it also involves the question of the extent to which, or of the modes in which, the control of monopolies by public authorities is desirable. Before we can give a satisfactory decision upon the complex constitutional issues which arise under a federation, we should first have formed an opinion upon the nature and scope of the powers which should be exercised by public authorities, whether national or provincial. The third desideratum is that the Commonwealth system of control should be supplemented by efficient and approximately uniform systems of control in the several States. Until this is secured, the Commonwealth system of control must be ineffective. A company may transfer its seat from one State to another, or its members may register as two separate companies in the one State. In the latter case, Company A may sell to Company B, leaving to it the transport or sale of goods beyond the State. The methods of Company B may be beyond reproach while the real offender is sheltering behind the trade and commerce limitation of the federal power.

(2) One very serious defect of the Acts for the Preservation of Australian Industries has been the absence of any adequate machinery for setting the law in motion. Hitherto the responsibility of taking action against offenders has lain with the Attorney-General of the Commonwealth. The 
results have not been satisfactory. The Labour Government has been accused of refusing to enforce the Acts in order to strengthen the case for nationalisation; and the Liberal Government has been accused of a policy of masterly inaction through fear of giving offence to a section of their supporters. How far these accusations have any foundation in fact may be open to question. They are, however, sufficiently plausible to illustrate the dangers of an administration which is subject to political influence. If administration is not to vary according to the caprice of the party in power, it should be independent of party or political influence. It should be entrusted, moreover, to a permanent body of a judicial or quasi-judicial character, and endowed with complete powers of investigation. These desiderata are apparently met by the Inter-State Commission Act of IgI2. ( $V$. infra, Chapter XII.) But the commission which that Act creates has so many other functions to discharge that its energies are likely to be dissipated in matters which have little or no relation to the problems under consideration. So long, moreover, as there exists a province of State control over trusts and combines in respect of Intra-State business, the work of a Commonwealth commission will need to be supplemented by tribunals acting within each State and charged within the area of their competence with like functions. The costs involved in the duplication of federal and State machinery, though by no means insignificant, would be relatively slight when compared with the ends to be gained. Those ends are of such importance 
as to justify a far greater outlay of expenditure than would in fact be required.

(3) By Section II of the Acts for the Preservation of Australian Industries, persons injured by reason of acts done in contravention of the more important sections may recover treble damages. This may seem alluring; but, when we remember the resources of the big business, it recalls the dictum that though men may be equal in the eyes of the law, they are not equal in the hands of the law. The pigmy who has to fight the giant in the courts, and knows anything of the uncertainties, delays and costs of litigation, will probably prefer to bear those ills he has than fly to others he knows not of. In the Canadian Combines Investigation Act, to which I referred in the preceding chapter, the costs of an investigation are borne by the Government. Some such provision appears to be desirable if the independent concern, the primary producer, the employee or the consumer are to be adequately protected under Acts for the prohibition of unfair competition. I shall return to this subject in a later chapter.

(4) The Acts for the Preservation of Australian Industries are not clear in the definition, which they express or imply, of unfair competition. American authorities advocate the prohibition of much which can only be brought within the Australian Acts by a liberal interpretation of their terms. Three examples may be quoted. (a) The Colonial Sugar Refining Company, in its contracts for the supply of sugar, binds the purchaser to buy only Australian produced sugar. As the 
company produces more than three-fourths of the total Australian output, the object of the provision appears to be to strengthen the control of the company while evading the letter of the Statute with respect to exclusive dealing. (b) It is not clear that the Acts would prevent a company from selling at a lower price in a particular area where competition is actual or anticipated, while maintaining higher prices elsewhere. The principle that prices should be uniform (subject to allowance for freight, etc.), though it may be implicit in the Acts, is not expressly affirmed. While a gross violation of the principle would be punishable, something less than a gross violation might escape punishment, although sufficient to enable a trust to strangle a competitor in a particular locality. (c) It is not certain that the Acts would prohibit a company from selling one grade of a particular commodity at a disproportionately low price in order to exclude competition in that particular grade.

The foregoing illustrations of the absence of clear and definite statement with respect to the meaning of unfair competition serve to suggest the desirability of amending legislation. But we must not overlook the fact that conditions vary so greatly in different industries that a Statute in prohibition of predatory practices must be in very general terms if statutory definitions, in their application to particular industries, are not to be sometimes inadequate and sometimes unduly repressive. The Australian Acts, it may be noted, permit such defences as that an alleged offence is not to the detriment of the public or is not 
unreasonable. They also provide that the court shall take into consideration the efficiency of the management, processes, plant and machinery, when determining whether competition is fair or unfair. The evident intention of the legislature is, not to preserve competition at all costs, but to preserve competition which is useful. By implication, reasonable combination which has for its object, not monopolistic exploitation, but the diminution of the wastes of competition, is not within the prohibition of the Statute. Now the determination of what is "reasonable combination" and what is "useful competition" cannot be made in general terms applicable to all industries alike.

I arrive at the general conclusion that, while some amendments might be made to the Acts for the Preservation of Australian Industries with a view to giving a greater definiteness to the notion of unfair competition, what is more imperatively needed is an independent commission for the administrative supervision and judicial enforcement of the general purposes of the Acts. The need has already received a partial recognition in the Inter-State Commission Act to which I shall refer in my concluding chapter. For the present, I wish to emphasise my opinion that the Commission should have the power of giving judicial decisions upon the matters involved in the definition of unfair competition. While such decisions might be subject to appeal on application to the High Court, appeals should be restricted to questions of law only. The decision of the Commission should be final as to the facts, and 
should be accepted as prima-facie proof that alleged offences are in contravention of the Acts. To leave the ordinary courts to work out by themselves a definition of what is fair and what is unfair competition, or to determine when a monopoly is or is not repressive, or to declare what is or is not to the detriment of the public, is to impose upon a purely judicial tribunal the necessity of adjudicating upon issues of which the determination more properly belongs to some body especially created for the purpose of dealing with such subjects.

Several reasons enforce this conclusion. (a) In the past, neither legislation nor judicial interpretation has proved equal to the task of keeping pace with the perverse ingenuity of private concerns. The attempts which have been made have not been without value; but they recall Demosthenes' barbarian warrior who protected that portion of his person which had just received a blow. The infinite variety of circumstances which exist in various industries, the rapidity of industrial progress, and the multiplicity of the forms of combination and competition, call for a wide discretion in the tribunal, and a flexibility of regulation, which are alien to the traditions of the Bench. (b) The judges are elected primarily for their knowledge of the law. But in dealing with the present subject matter a special need exists for a tribunal which will include men of wide business experience supported by a staff of experts. (c) A satisfactory administration of antitrust legislation involves powers of negotiation with business concerns, powers of mere investiga- 
tion, powers of calling upon a trust to revise its scheme of prices, powers of making specific recommendations to the legislature, and powers of dissolving a repressive monopoly under conditions which shall adequately secure the purposes which the legislature has in view. These powers should be exercised by a special administrative body, capable of giving a judicial decision as a court of first instance, but also capable of acting in more direct and expeditious ways where the circumstances of the case admit of this being done consistently with the attainment of the purposes which the legislature has in view.

The foregoing argument derives additional enforcement from the history of anti-trust legislation in the United States. Mr. Van Hise writes, "If the most ardent advocate of court procedure against corporations in restraint of trade, through amendments of existing law to be enforced by the courts, believes that there is any possibility of redressing the wrongs of the individual and securing the rights of the weak, he must indeed be blind to the experience of the last fifty years of development. The problem of combination in restraint of trade is one too large, too complex, and too irresistible to be handled by the courts." 1 The author concludes that there should be national and State commissions, able to take action without complaint, acting on complaint without expense to the complainant, and armed with all necessary powers. "The law should forbid unfair practices, but the specific unfair practices should not be enumerated; this would leave it to the

1 "Concentration and Control," pp. 23I-2, 192. 
commission to stipulate those practices which are unfair. By this procedure the list of unfair practices and their definitions could be amended from time to time as the exigencies demand; whereas if the unfair practices were enumerated in detail in the Statutes there would be sure to arise situations which are not adequately covered." 1 The commission, it is also urged, should work out details as to what is reasonable and permissible co-operation, and as to the meaning of the rule of law laid down by the courts prohibiting monopoly. ${ }^{2}$

Professor J. B. Clark remarks that, in the constructive task of preserving competition, the one-price principle bids fair to play a leading part. After making some useful suggestions as to possible qualifications of this principle in actual practice, the author concludes in favour of an executive commission to whose judgment and experience such details might be left. ${ }^{3}$

I have referred at some length to the lack of clear and definite definition in the Acts for the Preservation of Australian Industries. I have urged the need for a special commission. Such a commission would have of necessity to work out some sort of code. Its experience and judgment should be directed to securing an ever-increasing definiteness in legal regulation so far as that is consistent with efficient administration. One very important part of its work would be to make definite recommendations to the legislature for

1 "Concentration and Control," pp. 252-3.

2 Ibid., p. $25 \mathrm{I}$.

3 "The Control of Trusts," I912, P. I Io. 
amendment of existing laws. In this connection, I may refer to two important changes which were made in an amending Act of Igro. Section 4 shifts the onus probandi. The defendant must prove that a contract or combination is not to the public detriment. Again, in the Act of I909, Section 7 penalised monopolising or attempts to monopolise trade or commerce, with intent to control to the detriment of the public the supply or price of any service, merchandrse or commodity. In the Act of Igro, the words italicised are omitted. The object of both of these changes will be apparent. The law seeks to widen the net.

\section{Ancillary Legislation}

In the earlier part of this chapter, I remarked that the legislative regulation of competition, as a means of monopoly prevention, involves in its primary aspect the prohibition of unfair competition. I have referred in detail to Australian Acts which endeavour to effect this purpose. But, in order that the legislative regulation of competition should be reasonably effective, certain specific evils need to be dealt with by ancillary legislation. The more serious of these evils are the abuse of patents, high tariffs and inter-stock holdings.

(I) The Abuse of Patent Rights. The Canadian Combines Investigation Act expressly empowers a commission to recommend the revocation of a patent. Obviously, a commission of the kind above suggested might make such a recommendation. It might also suggest to the legislature the 
conditions under which, in its opinion, a particular patent should be retained. It appears to me, however, that the commission should be directly empowered to order the forfeiture of patents which have been simply brought up to be pigeonholed. Professor Ely, in his brief reference to the subject of patent legislation, alludes to two other remedies both of which have a prima-facie justification. One proposal is to reserve to the Government a right to purchase any patent at an appraised valuation. The other proposal is to grant patents only on condition that the use of the patent shall be free to anyone on payment to its owner of a reasonable royalty of which the amount is to be determined by a board in accordance with carefully elaborated principles. ${ }^{1}$

(2) The Tariff. Any tariff which is protective gives a stimulus to local production. Where the tariff is excessive, local production tends to exceed the demands of the local market. This in turn leads to trusts and combines which take advantage of the exclusion of foreign competition in order to exploit the home consumer while exporting the surplus at such price as may be obtainable in foreign markets. The phenomenon finds its most striking illustration in the United States and Russia. In the latter country, which boasts a higher tariff than exists anywhere else in Europe, there are, according to a recent estimate, nineteen hundred trusts. ${ }^{2}$ According to $\mathrm{Mr}$. Macrosty, "The weakness of every form of com-

1 "Monopolies and Trusts," I912, p. 267. Cf. Van Hise, "Concentration and Control," pp. 268-70.

2 Vide M. E. Hirst, "The Story of Trusts," p. Ioo. 
bination in the United Kingdom is due to the free admission of foreign competition." 1 The abolition of the tariff in protective communities, in the hope of its proving a panacea for the trust problem, cannot be defended, since it might prove disastrous to local industries. At the same time, there is every reason for jealously watching the tariff, and for diminishing it or removing it wherever either of these may be done without detriment to the public welfare.

(3) Inter-stock Holding. One of the chief obstacles in the way of maintaining healthy competition is the controlling influence exercised by the same persons in nominally independent concerns. The evil is particularly marked in the United States. Professor Clark estimates that less than a third of the capital invested in the railways is represented by any effective voice in their management. The author urges that, while individuals should be allowed to invest in competing corporations, they should not have a voice in the government of more than one such company. ${ }^{2}$ Similarly, while one corporation may hold the stocks of others as investments, it should not be allowed to exercise its voting power to control them. ${ }^{3}$ The State of Georgia has already a law prohibiting a corporation from purchasing stock in any other corporation where the effect is to defeat or to lessen competition in their respective businesses."

1 "The Trust Movement in British Industry," p. 342 .

2 "The Control of Trusts," I912, p. 153.

3 Ibid., p. I50.

-Vide Van Hise, "Concentration and Control," p. 193. 


\section{CHAPTER VII}

THE REGULATION OR CONTROL OF THE PERSISTENT MONOPOLY

\section{Limited Value of Policies Previously}

CONSIDERED

In the preceding chapters, I have discussed two policies whose primary purpose is that of preventing monopolies from coming into being. As I have already remarked, these policies have a value even in relation to the established monopoly. They may be the means either of breaking it or of checking its abuse of power. But the policies, either singly or in combination, do not offer a solution of all the problems which arise in relation to monopoly.

The dangers of attaching an exaggerated importance to publicity should be apparent to anyone who is at all acquainted with the history of the trust movement. Light may be the best policeman; but it must not be the only policeman. It may prevent a trust or combine from gross abuses. If it were relied on to do more than this, it would, at any rate in many cases, tell for industrial somnolence. We may suppose, for the sake of argument, the existence of a commission armed with adequate powers of investigation and supported by strong public opinion. Under such 
conditions, while the commission might be able to prevent a trust or combine from making excessive profits at the expense of other parties, this result might be gained at the expense of a declining efficiency in the conduct of the business concerned. A trust may say, "We can make so much profit with safety. Why should we trouble to make more for the sake of other people?" So long as a trust or combine is not guilty of grossly unfair practices, and does not make excessive profits, publicity has little or no material upon which to fasten. But a trust or combine may be innocent in such respects without being an ideally effective organisation of the particular industry which it controls. What is needed is some policy of monopoly control which will prevent abuses without imperilling the standard of efficiency.

On the other hand, the legal regulation and administrative supervision of competition, while they may succeed in restoring competition in some fields of industry which are now subject to monopoly control, are likely to prove inappropriate or inadequate in at least three forms of established monopolies which present peculiar difficulties and call for special regulation or control.

(I) Monopolies in Naturally Non-competitive Industries. Some monopolies exist in a business or industry which is naturally non-competitive. Where a company has an exclusive ownership of the sources of supply, or where a railway is the only carrier of persons or goods, or where the supply of gas, electricity or water to a metropolitan area is in the hands of a single concern, or 
where the producer of raw material must sell to the nearest mill if he is to sell at all, the prohibition of predatory competition is valueless for the reason that there is no need to resort to such competition. The monopolistic business may prey on the producer, employee or consumer. It cannot prey upon competitors, for competitors are excluded from coming into existence by the very circumstances of the case.

(2) The Business Unit Monopoly. In any industry where the advantages of large scale organisation are such as to enable the business unit to fix prices at its own discretion, though the restoration of competitive industry by restriction of the size of corporate undertakings might be theoretically possible, it would be undesirable for reasons stated in an earlier chapter.

(3) Monopolies Based on Honourable Understandings, etc. The prohibition of predatory competition may prove ineffective through inability of the law to compel capitalists to compete where they find it practicable and profitable to combine. The forms of combination are manifold. The most insidious and difficult to cope with are secret agreements, honourable understandings, and the tacit acceptance by small and nominally independent concerns of a scale of prices fixed by a large business which occupies a dominant position. The last-mentioned example is not in form a combine at all; but the effects are substantially the same. In Australia, there are two companies for the conversion of raw sugarinto refined. One company is large, the other small. Whenever an advertisement appears in the Press affecting 
the scale of prices charged by the large company, it is accompanied by an advertisement indicating a corresponding change in the prices charged by the small company. The investigations of a Royal Commission failed to prove anything in the nature of agreement or honourable understanding between the two companies. It was clear that the small company preferred to take advantage of the scale of prices fixed by the large company rather than run the risk of extermination in a war of competition. It entered into no sort of agreement to that effect. It simply instructed the Press to follow the advertised charges of the dominant company.

Even where several concerns are capable of mutual competition, as in the case of the coastal shipping industry in Australia, what is to prevent them from entering into an honourable understanding as to prices or areas of operation? I put this question to a business man. He answered : "If shippers or passengers suffer from such an understanding, let them organise a competing concern." I asked him if he would put his own money into it. He said he would think about the matter. I ventured to suggest that he should think twice. Nominally, the Australian coastal trade is open to all comers. Actually and substantially, so far as I can learn, the existing companies have a sufficient control of the greater part of the carrying trade to keep fresh rivals from coming into the field. I should perhaps say the sea! But even supposing my friend to be successful in starting a competing concern, and doing him the compliment of supposing that he 
has command of sufficient capital and ability to avoid being crushed in the initial stages. What then? How long would he remain a competing concern? Suppose my friend to be chairman of directors. Would he advise his co-directors to maintain a Herculean struggle with the older rivals? I can imagine him speaking to a meeting of the board of directors: "Gentlemen, if I felt free to act as I thought most conducive to the public interest, I might perhaps urge a continuance of competition. I say perhaps. As a matter of fact, I am not at all convinced that our standing in with the so-called combine would be to the public detriment. Indeed, I must confess that, since I entered the important business which we have the honour to direct, my opinion upon combines has undergone a change-a serious change, gentlemen. (Hear, hear.) But in any case, these considerations are quite theoretical. We are here to represent the shareholders. This is a private business, not a philanthropic institution ; and I feel bound to express my opinion that if you want reasonably high and secure dividends in the future, you will stand in with the combine. I do not advocate any formal agreement. The law must be respected; and such an agreement might be open to legal objection. But I believe we are able to come to some sort of understanding which will put an end to the present policy of price cutting, which is becoming each day more suicidal. The real question which we have to settle to-day, then, is whether we are to go for a policy of combination and reasonably secure dividends, or are we not? I put the question to you as practical 
business men. Those who are for combination please say 'Aye.' (Emphatic chorus of 'Ayes'.) On the contrary. (Silence.) Gentlemen, the 'Ayes' have it. I can only congratulate you on the unanimity and promptitude with which you have arrived at an important decision. I look forward to an era of increased prosperity for our business. I need not say that, as regards freights and passenger fares, we shall only adhere to a scale of prices which is fair and reasonable to the shippers and the public. I am sure that the last thing we desire is to charge the shippers or general public unfair prices. I do not mean that we should allow the shipper or the passenger or the public to have a voice in declaring what is a fair price. We run this business; and we are entitled to declare the prices at which we are prepared to carry goods or passengers. The business is a private business; and I deprecate, as I am sure you all deprecate, any interference with our right to determine for ourselves what is reasonable, apart from unwarrantable intrusion on the part of the shipper, of the passenger, or of the public. The shippers and passengers are interested parties ; and the Parliaments who represent the public are comprised for the most part of men who have no appreciation of the first principles which should guide a commercial undertaking. I need not occupy your time in explaining what these principles are. We are all business men. But I may be allowed to say that our first duty is to the shareholders. And I am confident that the policy which we have adopted to-day is in their interest." 
In the past, combinations effected by agreement, honourable understandings, etc., have often owed their origin to the lack of an effective system of legal and administrative control directed to the prohibition of unfair competition. Assuming the existence of such a system, the formation of combines, though less frequent, would still continue. Authors who rely upon the policy of regulating competition, as a means of preserving competitive industry, profess to find a consolation in the transiency of many of the combinations effected in the way indicated. Experience, however, has amply demonstrated that the chances of one concern breaking away, or the chances of a new competitor entering the field, are frequently too remote to be relied upon as a means of safeguarding the interests of the community. Long before either of the contingencies indicated occurs, if either of them ever does occur, the community, or classes of the community, may be exploited to an extent which is calculated to give plausibility to the view that the sooner all business is nationalised the better.

With regard to such combinations, it should further be noted that the task of discovering a remedy for them is the more difficult because they often mean an increased productive efficiency. If they were altogether bad, the wisdom of legislation directed to smashing them would require no justification. In point of fact, however, while they restrict competition, they make possible the advantages of co-operation. They may contribute to the stability of industry, to the maintenance of standard wages, and the lowering of 
prices to the consumer. The trouble is to ensure these various advantages. In a world where business is business, it is more than probable that the power of fixing prices will not be exercised in the common interest. It will be mainly directed to increasing dividends.

From whatever point of view we look at the subject, we arrive at the conclusion that monopolies which arise from agreement or honourable understanding, no less than the business-unit monopoly or the monopoly in naturally non-competitive industries, call for some sort of regulation or control by public authorities. Incidentally, such regulation or control would check the formation of many combines which are out, not for the advantages of co-operation, but for monopoly profits. But the paramount purpose of the system of public regulation or control should be to ensure that the profits of private concerns, which enjoy a monopolistic control, represent the economies effected by co-operation and not the fruits of monopolistic exploitation. I do not mean that the State, or a public authority in the name of the State, should step in and exercise some form of control wherever a monopoly is once firmly established. Some monopolies do not abuse their powers. What I mean is, that the State should be armed with adequate machinery to control a monopoly which does abuse its powers. And it should act promptly as well as effectively. If it does not act promptly, it will be confronted by a difficult dilemma. I may put a concrete case. A monopoly is established; it makes excessive profits by unfair prices to the consumer. The 
value of its shares is enhanced. People buy those shares at prices based, not on a fair estimate of costs of production, but on an earning capacity which is largely determined by the mere fact of a monopolistic control of the market. If, at this stage, the State steps in, how will it act fairly to the shareholder without penalising the consumer? Or fairly to the consumer without penalising the shareholder? Someone will have to suffer; but the suffering will be less in proportion as Parliament or public authorities act with promptitude and a due regard to all the circumstances of the case.

I have referred to three classes of monopolies with respect to which the policies of prevention referred to in previous chapters are inappropriate or inadequate. In later chapters, I shall discuss two policies which, within their respective limits, are in my opinion appropriate and adequatenationalisation and the public control of prices. In the present chapter, I wish to refer to two policies which are often urged, but which appear to me to have so limited a value as to dispense with the need for detailed treatment-public competition, and the limitation of profits.

\section{Public Competition}

The legislator who advocates public competition with a private business may desire to secure a supply of material for some department of State, or to prepare the way for nationalisation, or to control an established monopoly. I limit my remarks to the last-mentioned of these objects. 
The value of public competition for the object indicated may seem to involve an examination of the relative efficiency of business as conducted by public authorities and private persons respectively. It appears to me, however, that even if we assume that a public business is likely to prove as efficient as a private business, the former is subject to peculiar objections or disabilities when it is in competition with a private monopoly. If it constructs its own plant, this will generally involve the scrapping of some of the plant of the monopoly or of independent concerns which may be existing under the shelter of the monopoly. If it purchases some existing plant, it will do so presumably at a market valuation which in all probability represents in part the result of monopoly control, and is therefore in excess of earning capacity as a competing concern. Further, the public concern, if it is to fulfil the purposes which the public control of a monopoly should have in view, is heavily handicapped in other ways. It would be expected to pay a higher price to producers for the raw material, or to pay a higher wage to employees, or to charge a lower price to consumers, or possibly to do all these things, while acting in competition with a private owned business, firmly established in control of the market, probably conducted with efficiency, and untrammelled by the difficulties of a concern pledged to be just to the producers, employees and consumers. Success under these conditions would generally be purchasable only at the cost of the taxpayer.

The foregoing difficulties, objections and dis- 
abilities of public competition, as a means of checking abuses on the part of an established monopoly, have a varying importance in different industries. In no industry can it be said that public competition is necessarily foredoomed to complete failure. The outstanding objection to the remedy is, not that it is impracticable, but that it is inferior to other remedies which will be discussed in later chapters. The State, with the vast resources at its command, has greater staying power than any private concern. If it likes to pay the price, it can even oust the private concern altogether. Indeed, experience goes to show that public competition, in proportion as it is effective, leads to public monopoly and ultimately to nationalisation. Speaking of competition in the railway business, Professor Ely remarks, "Either the Government or the private corporations must finally abandon the field. If the Government service is poor and its competition ineffective, the result is general dissatisfaction. If the Government has an excellent administrative system, and competes seriously with private companies, it can hardly fail to drive them out of the field, because its resources are so much vaster. Even if the Government does not push its superior capacity so far as a private corporation would, but allows its rivals to exist, those who feel its competition keenly will complain bitterly of what they regard as oppressive action on the part of the Government which they themselves help to sustain. What might have been foreseen, and undoubtedly was foreseen by deep thinkers, actually happened in Germany. Private lines were purchased, and 
have since then been operated as a part of the Government system. In France there has been a slight attempt at competition through the ownership and operation of lines by the Government. The best lines, however, appear to have always been private property, and there is no evidence of any effective determined competition on the part of the Government. The consequence has been dissatisfaction with the Government service." 1

The fact that public competition, if effective, is apt to lead to nationalisation, will be regarded with approval or disapproval according to the point of view of the observer. Those who regard the fact with disapproval will find in it an additional objection to public competition as a means of monopoly control. But even those who regard the fact with approval must concede that public competition is less a solution of the problem of monopoly than a step towards the solution. I reserve the discussion of nationalisation for a separate chapter. For the present, I content myself with two observations. (I) Assuming the nationalisation of a particular industry to be desirable, I believe that it would be better in most cases to nationalise the industry as soon as it reaches the monopoly stage without having recourse to the expensive and relatively inefficient device of public competition. (2) Assuming the nationalisation of an industry to be undesirable, I shall hope to show in later chapters that the control of an established monopoly in that industry can generally be met by means more effective than

1 "Monopolies and Trusts," pp. 69-70. 
public competition, and involving a less serious extension of the sphere of public responsibility.

\section{The Limitation of Profits to a Fixed Percentage on Capital}

An Act which incorporates a gas company, or grants any franchise or privilege, may limit profits to a fixed percentage on capital outlay. If it fails to do so, supplementary legislation may make good the omission. Similarly, in the case of any monopoly, however acquired, legislation or administrative machinery may limit profits to such a percentage on capital as may be adjudged to be fair and reasonable.

The policy of limiting profits has a peculiar attraction to the individual who is too concerned about equality of distribution to care about efficiency of production. Regarded in relation to the problem of the control of established monopolies, the policy is open to grave objections. In the first place, it affords no adequate protection to either producer, employee or consumer. The monopoly might be just to all parties; but there is no guarantee that it would be so. In the second place, the policy is likely to tell for inefficiency in the conduct of the business rather than for an equitable distribution of profits as between the many interested parties. A private concern which would endeavour to increase its profits if those profits are to go to someone else would be an anomaly in a world where business is business. In the third place, the policy might be partially 
nullified in practice by nepotism, or by extravagant salaries to directors, managers, etc.

The foregoing objections go to show that the policy under consideration would be unsatisfactory save in a qualified form and as an integral part of a policy to which I shall refer later on-the public control of prices. 


\section{CHAPTER VIII}

\section{NATIONALISATION}

THE discussion either of nationalisation or of the public control of prices leads into very controversial territory. Some people declare the latter policy to be impracticable ; others declare it to be inadequate. In later chapters, I shall endeavour to show that, in some industries, it is both practicable and reasonably adequate. In the present chapter, I state my reasons for not accepting nationalisation, which has the merits of being obvious and relatively simple, as a policy for universal application in the case of the persistent monopoly.

\section{Definition}

Nationalisation implies exclusive public ownership. It does not necessarily involve public management. Where a State assumes the ownership of a trust property as a going concern, considerations of general policy, or the particular circumstances of the case, may justify the State in leasing the property to private individuals, subject to conditions which would safeguard the interests of producers, employees and consumers. Such conditions, however, really involve in a greater or less degree a consideration of the policy 
of price control by public authorities. This is specially apparent with regard to the wage question. For the present, therefore, I shall assume that nationalisation means exclusive ownership, management and control by publicauthorities.

\section{Nationalisation and Socialism}

At the outset, I desire to state my attitude towards public ownership in general. On the one hand, I am not with those who regard such ownership as a thing so bad in itself that it should be avoided wherever possible. It has many advantages which are both indisputable and apparent. On the other hand, I am unable to attach to public ownership the value which is assigned to it in the theory of socialism. If the socialist be right, legislation should be persistently directed towards the public ownership and control of the means of production, distribution and exchange. The conclusion appears to imply the nationalisation of trusts as they arise. But I do not think the time has yet arrived when the statesman would be justified in assuming the practicability, or even the desirability, of the economic reconstruction for which the socialist contends. As a consequence, when the question of nationalising a particular industry comes under discussion, I feel that I ought to consider all the particular circumstances of the case. I feel bound to ask whether the industry would be as efficiently carried on in public as in private hands. I feel bound to consider, and to attach weight to, a number of objections which might be regarded as 
negligible if we could assume that public ownership and control is the ideal form of industrial organisation. Many people who are called socialists to-day do not adopt this assumption. Others do. Those who do, will disapprove of some of my conclusions. In any case, I can only submit those conclusions for the sympathetic consideration of the reader.

\section{Where Nationalisation is "Prima Facie" JUSTifiable}

In considering the case for or against the nationalisation of monopolies, it is important to bear in mind that special cases call for special remedies. Several examples may be quoted. Transport services are so essential to the welfare of the community, and their powers of control and exploitation are so numerous and complicated, that the case for their nationalisation has a peculiar cogency. I do not say it is conclusive; but it has a special justification. Before passing a final judgment, the circumstances of each case must be considered. (2) Industries which vitally affect the health of the community are another example. The sacrifice of infant life which goes on in the modern metropolis, through the supply of impure milk, constitutes a strong if not conclusive reason for public ownership. (3) Where private ownership threatens the depletion of the national resources, nationalisation may prove to be the only adequate way of safeguarding the national welfare. The private owners may be men of high business integrity. But, as business men, they are not concerned with the future of 
the country. They are out for high dividends. They will pursue those dividends regardless of the fact that in doing so they exhaust the national resources and pave the way for national bankruptcy. The coal-mining industry in Great Britain is an apparent illustration. ${ }^{1}$ (4) With regard to a trust or a combine which cannot be adequately controlled save by nationalisation or a public regulation of prices, the former remedy may be necessary if the latter remedy is impracticable.

The nature of an industry, or the special circumstances under which it is carried on, may tell against, as well as for, its nationalisation. The Australian Sugar Refining Industry offers an illustration. The Report of a Royal Commission, published in December, I9I2, when referring to the proposal to nationalise the industry, begins with a brief reference to the advantages of the proposal. Public authorities would fix the prices of refined and raw sugar, presumably with a due regard to the interests of consumers and millers respectively; and the interests of growers could be protected by making the payment of the full price for raw sugar conditional in the case of each mill upon a payment by that mill of a fair price for the cane. Any profits resulting from the public control of the refining industry would go to the public purse.

Notwithstanding these advantages, the Com-

${ }^{2}$ Cf. Van Hise, "Centralisation and Control," pp. 89-97, 228,263 . The author does not urge nationalisation as a remedy for the evil in question. But he gives some striking examples of the evil, and the remedy which he suggests-viz. public regulation-does not appear to me to be adequate in all cases. 
mission did not support the proposal to nationalise the refining industry. The reasons deserve brief statement :

(I) The wastes of the competitive régime-so frequently urged as a ground for extensions of public ownership-are negligible in the refining industry owing to the predominating position of the Colonial Sugar Refining Company.

(2) The purchase of the refineries at their present market value would be likely to involve the Treasury in a financial loss. Refining profits have been made under monopoly conditions. Those conditions have given to the existing plant a value in excess of earning capacity if the plant were taken over by public authorities pledged to do justice to the producer, the employee and the consumer. The question of compensation, always difficult, presents some special problems where monopolistic conditions give an artificial value to the existing plant.

(3) The various difficulties with which public ownership has to contend, and the high degree of business skill displayed in the refining industry in the past, combine to suggest that public ownership would involve a loss in economic efficiency. If, as might prove to be the case, the loss more than counterbalanced any excessive profits made by the present owners, either the consumer or the taxpayer would have to make good the difference.

(4) Recent improvements in the manufacture of mill-white sugar (a commodity which threatens to become a serious competitor of the refined article) make the purchase of the refineries at the 
present stage a speculative venture. If the Commonwealth bought the refining plant, and if the opinions expressed by some competent experts as to the future of mill-white sugar should prove correct, the Commonwealth would have on its hands a dying industry. It is impossible to say whether the expectations of the competent experts referred to will be realised. They may not be; and they may be. The doubt on the subject, however, is one reason why the Commonwealth should not, at the present juncture, venture upon the nationalisation of the refining industry unless other means of adequate control are not available.

No one of the foregoing reasons, taken singly, may appear convincing to the individual who is predisposed to advocate nationalisation. Their strength lies in the combination of them. Looking at all the circumstances of the case, the Commission concluded, as I believe rightly, that the nationalisation of the refining industry is not at present desirable unless other means of adequate control are not available. Other means of control are suggested in the form of price regulation by public authorities. ${ }^{1}$

\section{Disadvantages of Public Ownership}

In discussing the policy of nationalisation, apart from the character and circumstances of the particular industry which is subject to monopoly control, several arguments which play a conspicuous part in the literature of socialism have either no value at all, or else a value materially

I V. infra, Chapter $\mathrm{X}$, "The Australian Sugar Industry." 
less than is often assigned to them. The argument in favour of nationalisation which is based on the wastes of competition, and the argument against nationalisation on the ground that keen competition between profit earners stimulates production, are generally negligible when we are considering public ownership as a panacea for the ills of a monopoly which is so firmly established as to defy the methods of control indicated in earlier chapters. Again, some people urge nationalisation as a means of ensuring a living wage to employees. But this end can be gained, without making the employee a civil servant, by public regulation of the rate of wage. Finally, little importance can be attached to nationalisation as a means of giving to the worker a new interest in his work. True, the profits of the nationalised business go to lighten the burden of the employee qua taxpayer. But this interest is less direct, if not less appealing, than the interest of the employee in a private monopoly. The tenure of the civil servant is independent of the maintenance of the standard of production. That of the private employee is not. On the other hand, the consciousness which the civil servant enjoys of being directly and immediately a servant of the public has not operated to give to the employee that pride in his work, that joy of service, which earlier socialists claimed for it. Truth to tell, both public and private ownership, under existing conditions, fail miserably when judged from the standpoint under immediate consideration. ${ }^{1}$ But I see no reason for supposing that the public IV. supra, Chapter II, "Syndicalism." 
regulation of the conditions of labour, at any rate in the case of firmly established monopolies, should not work as effectively in the desired direction of co-operative production as the policy of nationalisation. ${ }^{1}$

Bearing in mind the foregoing remarks, and excluding the special character of particular industries, the choice between the nationalisation of a monopoly and the public control of prices mainly depends upon the practicability of the latter method of control and upon the relative efficiency of public and private ownership. In the present chapter, I address myself to the lastmentioned subject. I am aware that some people speak slightingly of efficiency. But, in the first place, we cannot divorce the question of efficiency from the more fundamental question of the national character. The discipline of reasonably hard work is no despicable element in the building up of character. In the second place, the business of the community has to be carried on ; and it is of great importance that it should be carried on as efficiently as possible. Viewed from the latter standpoint, the chief disadvantage of public ownership, as applied to a particular industry, is the suspension of the struggle for existence in that industry. A public business may be carried on at a loss; a private business must be carried on at a profit if it is not to go under. The consciousness of this difference has some value, as a spur to efficiency, for every grade of individual concerned-directors, managers and employees generally. Of course, where public ownership is 1 Cf. infra, Chapter IX, "Public Control of Prices." 
exclusive, profits can be assured by the simple device of charging high prices to the consumer. But this does not bring into operation the struggle for existence; on the contrary, it is a means of blinding the general public as to the relative inefficiency of the public business. No doubt a private monopoly can also raise prices to the consumer. But I am assuming for a moment the practicability of an effective check upon this way of disguising inefficiency. Further, the profits and the losses of a private-owned business affect those who are engaged in it. The profits and losses of a public business are passed on to the general public. The difference is not like that which, according to an eminent American judge, exists between two things between which there is no difference. It may involve just the difference between efficiency and inefficiency. The maximum of efficiency is difficult to attain, and still more difficult to maintain. Even in private hands the big business is apt to become somnolent. In public hands that danger is even greater.

Public ownership, again, means the conduct of a business by the civil service. I do not wish to speak with disrespect of that very important part of the modern community; but I think most impartial observers will agree with me that the civil service suffers in efficiency in several ways. (I) If a civil servant be indolent or incompetent, and he may be one or the other-I will not venture to suggest that he may be both-he is not so readily dealt with as the employee of a private owner. (2) Efficiency is only maintained in a business by frequent administrative reform. In 
these days, a business does not hold its own by standing still. But, to most of us, whether we are civil servants or not, reform is not a pleasant thing, if we are the persons to be reformed. To be frank, we do not like it. As a consequence, we are apt to resent it; and the resentment may take the form of making things uncomfortable for the reformer. If we can. It is just here that one of the difficulties of the organisation of the civil service becomes apparent. If a public official in a position of authority displays a zeal for reform, political influence may be brought to bear in order to make his position uncomfortable or even intolerable. The fear of such influence has often killed the zeal for reform in the civil service. It begets a desire to go along with the minimum of friction. Hence a spirit of routine which may easily mean a minimum of efficiency. There is, unfortunately, an element of truth in the saying that the good official is the man who combines laziness with extreme accuracy. The manager of a private business knows that his directorate will support activity, enterprise, initiative and economy. The manager of a public business may have reason to believe that his controlling board desires these things; but he knows that the board, even if it be composed of men who will work as hard for the public interest as they would for their own, is liable to disturbing influences which are relatively absent in the case of a private-owned business.

(3) The civil service labours under a disadvantage with respect to appointments or promotions. Party or personal considerations, or 
the desire to avoid making enemies, often tell for the selection of individuals who are not the best fitted to discharge the responsibilities imposed upon them. I do not think, for example, that any private concern could afford to attach to mere seniority the importance which is attached to it, and threatens to be attached in an increasing degree, in appointments in the civil service. The private concern is out for profits; it has therefore a special inducement to choose the most capable men. The public concern, on the other hand, is too often out for a policy of following the line of least resistance. It has in mind the possibility of questions in Parliament, of correspondence in the Press, etc., etc. It means well, but it would be less than human if its divided thought did not occasionally, if not frequently, betray it into undesirable appointments. The danger is serious. More and more, with the increasing complexity and magnitude of industrial organisation, efficiency depends upon brains, and especially upon the brains of those who direct or manage a business. An English visitor in the United States, who was taken over a trust plant by the President, remarked, "You appear to me to pay exorbitant salaries to your higher officials." The answer was, "We do so because it pays. Brains are cheap at any price, and if we make high profits, it is largely because we allow nothing to stand in the way of our getting the best brains we can. Personal considerations do not count; money does not count. What does count is ability."

The foregoing disadvantages of public ownership will be generally admitted. Mr. Sydney Brooks, 
speaking of the United States telephone system, remarks, "But alertness and enterprise such as this cannot reasonably be expected from a Government Department. The characteristics of the bureaucratic mind and temperament forbid it. The organisation of a Government office, with a virtually irremovable staff, forbids it. The spirit of officialdom, with its traditions of subordination, its narrow professional outlook, its unwillingness to concentrate responsibility, its insensible stifling of initiative, forbids it. When humanity has reached the plane on which the ideal of social service is a stronger impulse to sound administration than the hope of gain, and when politicians are inspired solely by an informed desire for the public good, things may be different. But at present a Government cannot raise or discipline its staff to the same level of efficiency as a commercial corporation, cannot act with the same freedom and directness as a board of directors, cannot pursue a business object without deference to a hundred influences and considerations from which the president of a company is exempt and which all militate against the first principles of commercial success, and cannot, therefore, display the same open-mindedness and elasticity, the same speculative foresight, the same promptitude in taking risks, without which an industrial undertaking, and especially one which is just groping its way from the experimental to the practical phase, is doomed to failure and stagnation. The marked and pervasive unprogressiveness of the great majority of the State telephone systems in Europe is not an 


\section{SUMMARY}

accident. ... I believe I am right in saying that not one of the innumerable discoveries that have transformed the technical and commercial management and development of the telephone in the last thirty years has emanated from a Department of State, that European Governments have been the last to adopt them, and that the verdict which experts are obliged to pass upon them, with perhaps one or two exemptions, is that they have not learned their business. Practically all the Governments of Europe in their conduct of the telephone industry have made. the vital and fundamental error of seeking efficiency through economy, instead of economy through efficiency. ... For practically a decade the Post Office and the National Telephone Company have been working side by side in the development of the London telephone service. The published accounts show that though the Post Office pays neither rent nor rates nor taxes, its working expenses have been seventy-three per cent. of its gross receipts, whereas those of the private corporation have been only fifty-six per cent. of its gross profits." 1

\section{General Conclusion}

Some of the above-mentioned disadvantages of public ownership may be removed or qualified in the course of time. Important reforms have already been effected, in some countries, in the control and discipline of the civil service. But, dealing with generally existing conditions, I feel

1 North American Review, I9I2, PP. 507-510. 
compelled to regard the nationalisation of monopolies as a policy of limited application. As I have already indicated, the special character of an industry, or the peculiar circumstances under which it is carried on, may be such that the arguments which I have advanced on the ground of relative inefficiency are more than counterbalanced by other considerations. Speaking generally, the question whether a monopoly should be nationalised is a question to which an answer should not be given until due consideration has been given to the possibility of securing the ends in view while retaining private ownership. If this can be done-and I hope to be able to show in succeeding chapters that it often can be donethe alternative should be preferred both on the ground of efficiency, and on the ground that, as between two remedies, the preference should be given as far as possible to that remedy which involves the lesser extension of the sphere of State action and responsibility. I have not enlarged upon this latter ground, but its importance will be conceded by anyone who realises the extent and character of the problems with which the State will have to deal in the near future-problems of education, of eugenics, of public health and morals, of the living wage, of the incidence of taxation, of land laws, etc., etc. 


\section{CHAPTER IX}

THE PUBLIC CONTROL OF PRICES

If the monopoly power to determine prices were subject to an effective public control, we might secure the advantages of large scale organisation without incurring the penalties which have so often accompanied those advantages in the past. But the objections to a public control over prices are numerous and plausible. They do not emanate from any one political party. Their force varies so much with different industries that any discussion of them in general terms must be very imperfect. I propose, however, to consider in the present chapter some preliminary questions with a view to preparing the ground for the concrete illustrations which I shall give in later chapters.

(I) Is it possible for public authorities to fix prices? The question exemplifies the spirit of fatalism in which many business men approach the discussion of political problems. Three things may be noted. (I) There is an important difference between an attempt on the part of the State to control prices generally and an attempt to control prices in an industry which has reached the monopoly stage. A monopoly does, as a matter of fact, fix prices; and if prices can be 
fixed by one party in its own interest, they can presumably be fixed, at any rate in the case of standard commodities, by public authorities in the interest of both parties. (2) The public control of prices involves no more than an extension of the principles which underlie existing legislation for the protection of the wage earner. Parliament, following the analogy of legislation for fixing the price of labour, may adopt one or other of three methods: (a) It may fix prices by law directly-the policy of the Legislative Minimum. (b) It may authorise representatives of the various branches of an industry to agree to prices-the policy of Wages Boards. (c) It may entrust the determination of prices to an impartial tribunalthe policy of Compulsory Arbitration. These policies may be adopted singly or in combination. (3) Whatever machinery be employed, the precise form in which the public control of prices is exercised may vary, and indeed would necessarily vary, according to circumstances. The public authority may fix a price straight out; or it may declare a maximum or minimum price; or it may prescribe a sliding scale of prices; or, again, it may call upon a monopoly to revise its prices. Moreover, a price award may be for a number of years, or be subject to revision on appeal of aggrieved parties. Finally the public control may extend over the whole range of an industry, or may be limited to particular branches. The common attitude of hostility to public regulation of prices is largely due to a failure to realise the variety of forms in which that regulation may be effected. 
The suggested impossibility of controlling monopoly prices deserves to be considered from the points of view of employees, producers and consumers respectively. With respect to employees, if an industry cannot afford to pay a living wage to employees, the industry should be either discontinued or else supported by State aid in one form or another. The Australian Sugar Industry is maintained primarily as a means of promoting the settlement of tropical areas by a white population. In such a case, I can see nothing unreasonable in calling upon the community to make good the difference between local costs of production (including therein a standard rate of wage) and foreign market prices. Further, assuming that an industry is able to pay an adequate wage, it is rather late to urge that public regulation with the object of ensuring this payment is either unreasonable or impracticable in an age when the Wages Board and the Court of Arbitration are familiar institutions. The real criticism of these institutions is, not that they attempt to do what cannot be done, but that they do not attempt to do as much as ought to be done. In the chapter on syndicalism, I referred to what I regard as the most objectionable feature of modern industrialism - the want, on the part of the labourer, of that interest in his work which comes of sharing in profits, responsibilities and control. It would be possible, in the case of an established monopoly, for either Wages Boards or Courts of Industrial Arbitration to promote a new comradeship of control, as well as of interest and sympathy, between employer and employee. At present, 


\section{I28 THE PUBLIC CONTROL OF PRICES}

the agreement of the Wages Board, or the decree of the Court of Industrial Arbitration, is limited to particular conditions of labour, more especially the rate of wage. The limitation has some justification so far as regards industries which are still in the competitive stage. But in the case of an established monopoly, the relative stability of the industry offers a new opportunity for experiments in the direction of co-operative production. Such experiments might be made with comparative safety; and, if they were successful in this limited area, the object lesson would have its value throughout the whole field of industry. A new impetus would be given to that movement in the direction of co-operative interest and control which is called for in the interest alike of civic character and of productive efficiency.

I am here expressing a plea, not for a direct democracy in industrial organisation, but for a democratic element in industrial organisation. A direct democracy would be even more unworkable in economics than in politics. What is needed is a reasonable compromise between existing forms of capitalistic control and the extravagancies to which I have referred in the chapter on syndicalism. The achievement of such a compromise may seem at present remote; it calls for qualities of moderation and restraint, no less than of enthusiasm. I should be tempted to despair of it if I did not believe it to be a practical necessity. Necessity is the mother of other things than invention.

With regard to producers, if in a particular industry a monopoly exploits the producer, I 
can see nothing unreasonable, unjust or impracticable, if public authorities compel the monopoly to pay a sliding scale of prices for the raw commodity, varying in accordance with the wholesale price at which it sells the finished product on the local market. As in the case of employees, so in the case of producers, a Bounty or an Import Duty may be required in order to ensure adequate returns. But the same justification holds good. In both cases, the justification for the protective policy is the difference between local and foreign costs of production. The public control of prices is a supplement to the protective policy for the purposes of ensuring a fair division of the profits in the industry among those who are engaged in it. The Bounties or Import Duty must be high enough to protect the local industry, but not so high as to throw an unfair burden on the taxpayer or the consumer. The Import Duty may be fixed at a certain amount; or it may fluctuate according to foreign market prices. In the former case, the local industry will have to make good, in years when foreign market prices are high, the hardships which it endures when the foreign market prices are low. Where the Import Duty fluctuates in accordance with foreign prices, falling as those prices rise, and rising as those prices fall, the effect is to standardise the wholesale price of the commodity on the local market. ${ }^{1}$

It is more difficult to speak in general terms of the protection of the consumer. Even more than in the case of the producer, the particular circumstances of the industry condition the form

${ }^{1}$ Cf. infra, Chapter XI, "The Australian Sugar Industry." 
I30 THE PUBLIC CONTROL OF PRICES

of the remedy. But some principles have a more or less general application. In the first place, the difficulties and objections to an attempt on the part of public authorities to control retail prices, and the fact that the control of a monopoly is generally exercised with regard to the wholesale price, impose practical limitations upon the extent to which a public authority should go, more especially at an early and experimental stage, in its endeavour to protect the consumer. In the second place, a broad distinction may be drawn between different classes of industries. In industries conducted on a free-trade basis, and liable to active competition from abroad, publicity and prohibition of unfair competition should afford a reasonably effective safeguard to the consumer. Where an industry is maintained by protective duties, a fluctuating Import Duty should serve to reconcile the just claims both of the industry and the consumer. So far, the public control of prices would only be indirect. But there are industries which do not fall under either of the classes mentioned. The manufacture of bricks is a typical example. If a trust or combine controls this industry, and if the trust or combine uses its power to exploit the general public (it is hard to speak of the consumer of bricks), I see no reason why the public control of prices should not take a direct form. A brick combine is not impossible; and such a combine may abuse its powers. I know this has been denied, but I am not so uncharitable as to take the denial seriously. A difference of opinion is only possible as to the best remedy. Some people 
would prefer nationalisation; some would advocate public competition. Either of these remedies may be defended on strong grounds. Personally, however, I see no reason why public authorities should not determine, from time to time, the price at which bricks may be placed on the market. This would involve a less serious extension of the sphere of public responsibility than either of the other remedies; it would conserve the advantages of private ownership as far as those advantages were in existence; and it would protect the general public-as consumers of bricks!

(2) On what basis could a public authority determine what is a reasonable price? Everyone will agree that prices should be reasonable. If they are to be reasonable, they must allow of a fair return on capital. What is a fair return? What is capital for the purpose of estimating a fair return? The former question is comparatively simple. A fair return must vary in accordance with the speculative character of the industry. In some industries 5 per cent. would not be too little; in other industries 20 per cent. may not be too high. The question as to the basis of capitalisation is more difficult. If the actually subscribed capital be adopted as the basis, the result may be to inflict a grave injustice upon existing shareholders. The same result might follow, if the cost of plant replacement is adopted without making an allowance for goodwill. On the other hand, if the market value of the shares be adopted, the result may be to crystallise profits which represent monopolistic abuses. I shall return to these difficulties when discussing, in 
later chapters, concrete examples of price regulation by public authorities. For the present, I content myself with two observations. (a) The difficulties to which I have alluded have not proved insuperable in the case of the American railroads. "In fixing the price on freight," remarks Mr. Van Hise, "it must be made reasonable; and this can only be determined by finding the value of the enormously complex and variable class of railroad properties, taking into account the extremely complicated business operations. Notwithstanding these difficulties, which by railroad men were declared to be absolutely insuperable and impossible to perform except by the experienced railroad man, the commissions have been, if not wholly successful, at least reasonably so. ${ }^{1}$ (b) While a public authority, in its efforts to determine reasonable prices on a fair basis of capitalisation, must necessarily take into consideration all the circumstances of the case, it may be affirmed as a general principle that every reasonable regard should be paid to the just claims of existing shareholders. The public authority should aim, as far as possible, at the prevention of gross abuses. The mere power to regulate prices would of itself be a useful deterrent upon gross abuses. But this is not enough. If private ownership is to be conserved, and reasonable co-operation is to be allowed, then the duty rests upon the State to watch with careful and even jealous eye the operations of every business

1 "Concentration and Control," p. 260. Cf., however, an article by Mr. R. E. T. Riggs, " Some Legal Problems of Railroad Valuation," in the Columbia Law Review, November I913. 
concern which has once secured a monopoly control. Where, however, gross abuses have been committed, and their perpetuation has given an inflated value to the market value of the shares, the responsibility rests upon the public authority to achieve the reasonable compromise between the interests of the various parties concerned.

(3) How could a public authority, which fixes a price, compel one party to sell, or another party to buy, at that price? The question has a special pertinency with regard to the price of labour. Public regulation of the price of labour in the past has not succeeded in eliminating the strike. Employees in a particular industry, lured by the prospect of an immediate gain, have struck for higher wages without pausing to consider how far a disloyalty to State decrees may react unfavourably upon wage earners as a class. The fact is as undeniable as it is regrettable. But the occasional recalcitrance of employees has not proved fatal to the system of the public regulation of the price for labour. The real position, so far at any rate as Australia is concerned, may be stated as follows: Although Wages Boards and Courts of Industrial Arbitration have not been an unqualified success, either as a means of preventing strikes or as a means of determining a just wage, past experience on the whole is sufficient to justify the belief that future development will be along the lines, not of reversion to a policy of laissez-faire, but of improving existing machinery so that it may be at once more just, more effective, and more calculated to strengthen the forces of public opinion which tell for social betterment 


\section{I34 THE PUBLIC CONTROL OF PRICES}

through legal and constitutional action. I cannot doubt that this represents the opinion of the Australian people to-day. I have yet to hear any person of public standing who will suggest that, because the industrial legislation has been in some respects a failure, it should be discarded. I believe that the vast majority of the Australian people would not tolerate such a suggestion.

But if this be the case, if it be true that we must contemplate an extension rather than a restriction of the extent of public control over the price of labour, what justification can there be for supposing that business men would refuse to sell or buy a particular commodity at the price fixed by public authorities? If it is practicable to effect a control over employees who have not large vested interests at stake, how much more practicable is it to effect a control over business men who have large vested interests at stake? They have given hostages to fortune. Even if they wished to be disloyal to public decrees, they have peculiar and substantial reasons for repressing the inclination. I concede that the public control of the price of a commodity, if it is to be effective, must be exercised with a due regard to the interests of all parties. I believe that it would be so exercised. If a business could show that an authorised scheme of prices made reasonable profits impossible, a prima facie, if not conclusive case, would exist for a revision of the authorised scheme. I cannot doubt that the fact would be recognised. And, so long as public authorities exercise their powers reasonably, a private business would be unlikely to defy their decrees. The 
history of industrial legislation with respect to the rate of wage goes to show that business men will accept a scheme of price regulation which is applied with a view to effecting a just compromise between the interests of conflicting parties.

(4) Has the community a moral right to dictate prices in the case of a business concern which runs the risks of private enterprise? It is difficult to take this question seriously, although it has often been asked. The risks of a monopoly under a system of price control are less than the risks of a business concern under a competitive régime. Some trust magnates want to have things both ways. They want to eliminate competition, and, at the same time, to be free from restraints which the elimination of competition may render imperative. They implicitly subscribe to the untenable argument that because all business involves some risks, a monopoly should be at liberty to exploit at will.

(5) Would not the control of prices weaken the incentives to effort on the part of a monopoly? In my reference to the policy of limiting profits to a fixed percentage on capital outlay, I referred to the danger that such a policy would work for inefficiency. Under a system of price control, however, so long as a trust sells an article of a standard quality at an approved price, the trust can retain the profits which it makes. From the point of view of efficiency, the difference is cardinal. Of course the public control of prices might be effected in such a way as to divert to third parties any increase in profits, whether or not resulting from a display of initiative enterprise or economy 
on the part of a trust. If this were done, the trust would become somnolent; and the community as well as the trust would be a loser. Two dangers have to be guarded against. One danger is that of allowing a trust to enjoy its present power of increasing its profits indefinitely without any regard to the claims of other parties. The other danger is that of destroying the stimulus to effort by depriving a trust of any opportunity to gain by increased efficiency. A sane policy of price control would involve, in most industries, the fixing of prices for a term of years, subject to review only in such cases as a miscalculation in the award of price. As an additional protection to the consumer, the prices should generally be fixed on a sliding scale which will enable a business of reasonably efficient plant $(a)$ to make a fair return on its capital, $(b)$ to increase that return on condition of charging lower prices for its output. Under such an arrangement, a trust would still have an adequate incentive to increase its efficiency. It would scarcely be deterred by the fact that a part of the fruits of its higher efficiency would be shared with the consumer. But let us suppose, for the sake of argument, that a trust does become somnolent, that it displays lax administration or a failure to utilise improved processes of manufacture which have been adopted in other countries, what then? My answer must be that the case for nationalisation would require a new if not convincing argument in its favour. I only defend the public control of prices in cases where private ownership is more efficient than public ownership. In the foregoing remarks, I have assumed the 
existence of a trust which enjoys a virtually exclusive possession of the market. In most cases of monopoly, however, while a trust or combine may so far control the market as to be able to fix prices at its own discretion, other concerns are in the field competing with the trusts as regards facilities of service, etc. In such cases, while public authorities may eliminate the possibility of competition in prices, their action in so doing is likely to intensify rather than diminish other forms of competition. The potential competitor, if he chooses to enter the field, may do so without fear of being immediately extinguished by the trust or combine fixing prices below costs of production. But even leaving the potential competitor out of account, it must be obvious that existing concerns will endeavour to do as much business as possible, in order to secure maximum profits. Mr. Van Hise, speaking of the competition between the railways from New York to Chicago, remarks that, though competition as to prices is non-existent, speeds have been increased, new steel cars have been introduced, more trains are run, and in many ways the service is becoming safer, more reliable, convenient and satisfactory. ${ }^{1}$

(6) Would not the public control of prices tend to establish a parasitic capitalism? The question has far more justification than the question just considered. The public control of prices, while it might preclude exorbitant profits, would tend to make moderate profits more secure. But three things suggest themselves. (a) As I pointed out

1 "Concentration and Control," pp. 274-5. 


\section{I38 THE PUBLIC CONTROL OF PRICES}

in the chapter on syndicalism, the problem of "parasitic capitalism" is a complex one which requires to be dealt with in a number of ways. The most obvious is the continuous readjustment of the incidence of taxation. Another way is the extension of the sphere of the public regulation of the conditions of labour. But such regulation implies the public control of the price of labour. While that control does not solve the problem of "parasitic capitalism," it is at least a contribution towards the solution. (b) We are not called upon to suppose that the public control of prices would be employed in such a way as to guarantee profits to private concerns. On the contrary, the object of public control should be, not to guarantee profits, but to make reasonable profits possible on condition of maintaining reasonable standards of efficiency. The policy of guaranteeing profits, like the policy of the limitation of profits to a fixed percentage on capital outlay, would strike at the very root of industrial efficiency. It would be preferable to have public ownership right away. (c) In judging the value of a particular policy, we have to consider practicable alternatives. Most of those who object to the public control of prices, on the ground that it might tend to establish a " parasitic capitalism," would presumably advocate the purchase of existing concerns by the public. But such a process of "buying out" is also open to the same objection. The essential difference between the alternatives is that one utilises, while the other discards, certain advantages of private-owned industry.

(7) Would not the public control of prices be a 
step towards socialism? Undoubtedly a preliminary period of price control would simplify the process of nationalisation. For one thing, the State would know more definitely what it was in for. In particular, it would be able to learn the real earning capacity of a trust. A trust would be afraid to under-estimate its profits, lest it should invite nationalisation on a basis of an inadequate compensation. On the other hand, if it over-estimated its profits, it would invite an unfavourable variation in its scale of prices. Between these dangers, it would be encouraged to make a correct disclosure of its financial position. Such a disclosure would simplify the complicated question of the compensation due to existing owners, and so minimise one of the difficulties in the way of extensions of public ownership.

While I admit that the public control of prices would simplify the process of nationalisation, I attach little weight to the suggestion that such control would be a step towards socialism. (a) In so far as the suggestion has any weight, it invites the rejoinder that the really important step towards socialism is the mere formation of trusts and combines. The trust or combine deprives the community of the safeguard afforded by competition against unfair prices. The public control of prices is simply an alternative safeguard. (b) The public control and regulation of private industry is one thing; socialism is another thing. It is, moreover, something which we are more likely to call into being than to avert by a failure to apply those milder remedies which common sense and justice dictate. (c) I am here concerned, not 


\section{I4O THE PUBLIC CONTROL OF PRICES}

with the application of public control of prices to all industries, or even to all monopolies. I have only in view those monopolies for which other forms of regulation to which I have referred should prove to be inappropriate or inadequate. Such monopolies exist as a matter of fact; and those who object both to nationalisation and to the public control of prices must show, if they can, some better method. It is not enough to get on the housetop and cry "Socialism!"

(8) Has not the public control of prices proved a failure in the past? The question is suggested by the fact that, with the development of the modern competitive system, the fixing of prices by law was discarded as unnecessary and mischievous. To-day, however, competition is breaking down in various fields of industry ; an ancient necessity has revived; and the practical question is how to cope with that necessity. In the case of the persistent monopoly, either the industry must be nationalised or else prices in it must be subject to public control. To infer that the latter is impossible because such control has proved a failure in certain periods of the past is to ignore the existence of new conditions which make ancient precedents inapplicable. I believe that flying was tried in the Middle Ages and failed; but it has succeeded in the twentieth century. Possibly the public control of prices may also succeed in the twentieth century. As a matter of fact, it is succeeding. English legislation has long exercised some control over the price of railway tickets; Russia controls the price of sugar; Australia controls the price of labour. 
In the United States the Inter-State Commerce Commission has long enjoyed important powers with respect to railway rates; and those powers have been exercised with results so conspicuously beneficial that even the railway magnates are driven to recognise their value. By a law of I 906 the Commission is empowered to fix maximum rates. By a law of IgIo it may suspend any proposed increase of rates pending investigation. In Germany, laws control prices in different industries. The most conspicuous example is the Imperial Law of May 25, I9Io. This law controls the sale of potash, allocates the proportions which may be sold locally or exported, and fixes the maximum price which may be charged on the local market.

(8) Do not political economists condemn the policy of a public control of prices? This question is often asked. My answer is twofold. (a) Whatever may be the opinion of economists, some of the ablest business men of to-day are prepared to welcome the public control of prices. When men like Andrew Carnegie and Judge Garry, President of the American Steel Trust, say that, in some cases, prices both can be and ought to be regulated by public authorities, I feel bound to attach 'weight to their opinion. Especially when I find the opinion supported by eminent statesmen and judges in America who have had exceptional opportunities of studying the trust problem.

(b) When business men object to the control of prices, and appeal to political economy, I feel bound to ask whether they are not thinking of the political economy of their school days. Po- 


\section{I42 THE PUBLIC CONTROL OF PRICES}

litical economy is not a stationary science. It is progressive. Not only because thought develops, but also because the economist has to deal with changing conditions. The advent of the trust and the combine invalidate the assumptions of classical economists; and many economists of to-day advocate extensions of the sphere of public control which in former times would have met with universal condemnation. "I see nothing for it," writes Professor Ashley, "but that, in countries where the monopolising movement is well under way, governments should assume the duty in some way of controlling prices." 1 Professor Wyman, of Harvard, after advocating the creation of an Inter-State Trade Commission with power to give relief against extortionate charges, concludes, "Confine its power over prices to reducing prices against which specific complaint has been made to it, but in disposing of such complaints let it fix the price in question for the future." 2 "I feel constrained to advocate," says Professor Seager, of the Columbia University, "government regulation of prices, just as most of us now advocate government regulation of railroad rates." s

In my brief discussion of the foregoing questions, I have endeavoured to anticipate several objections which may be urged against the public control of prices. But such control may be exercised in so many ways, and these ways are so conditioned

1 "Surveys Historic and Economic," p. 388.

" "Annals of the American Academy of Social and Political Science," July I9I2.

3 Ibid., p. 245. Cf. also Van Hise, "Concentration and Control," p. 268, and Haney, "Business Organisation and Combination," p. 384 . 
by the circumstances of the particular industry concerned, that the procedure which I have adopted may seem open to serious objection. But some objections relate to public control of prices in any conceivable form ; other objections, in so far as they have any value at all, only apply to forms of public control which I would not venture to advocate. I wished to anticipate these various objections in order to clear the ground and to secure a sympathetic hearing for the public control of prices within the limits which I propose. I do not advocate a wholesale adoption of the policy. I assume the adoption of the two policies to which I referred in earlier chapters-publicity and the public regulation of competition. If these policies are in active operation, with an adequate system of legal and administrative control, monopolies in most industries will be either prevented or rendered innocuous. But, for monopolies which do not yield to these measures, I believe that a remedy may be found either in nationalisation or in the public control of prices. I therefore submit the last-mentioned form of monopoly control as an alternative to nationalisation, as a remedy applicable in the case of some particular monopoly, and as a remedy which must vary in its application according to the conditions of the industry over which that monopoly has a control. Upon the last-mentioned point I wish to lay special emphasis. Some industries are purely local, while others exist mainly or partly with a view to export in competition with the world's market prices. Some industries can only be kept alive by a system of Bounties or Import 
I44 THE PUBLIC CONTROL OF PRICES

Duty, while others do not need these artificial supports. In protective industries, the public control of prices may be carried further than in free-trade industries. But in both classes of industries, all the circumstances of each case have to be taken into consideration ; and these circumstances condition the form, while they may limit the application, of the system of price control by public authorities. 


\section{CHAPTER $\mathrm{X}$}

THE NEW SOUTH WALES GAS ACT, I9I2

AN Act of the Parliament of New South Wales, passed in IgI2, regulated the price of gas within metropolitan areas. The Act excited a fury of controversy. During its passage through the Legislature, two opposed views were urged which appear to me to be erroneous. According to one view, the State may insist on the reduction of dividends to an amount representative of a fair interest on the capital which has been actually paid up by the shareholders. The State may say to a company, "Although in the past you have declared a dividend of I $_{5}$ per cent. on paid-up capital, for the future you shall not declare a dividend of more than 7 per cent." On the face of it, this may seem reasonable. Certainly, if the rights of the company when first incorporated had been so limited, there could be no ground for complaint. But when a company, which has been making 15 per cent., is suddenly told that it shall not make more than 7 per cent., a practical difficulty arises. We must not gloss over this difficulty as if it did not exist. It does exist. It ought to be faced frankly. Although the company may be paying I5 per cent. on its paid-up capital, it may only be paying 5 per cent. upon the market value of the shares. The shares may be owned by original shareholders ; but we are not entitled 
to assume that they are. A large proportion will probably be held by more or less recent purchasers. A shareholder who has invested $f$ Ioo may find that the market value of his shares is reduced to less than one-half of the money which he paid for them. The arrangement may confer an immediate benefit upon consumers; but, from the point of view of the company, its general effect is to make existing shareholders pay for the profits which have been made by shareholders in the past. If the State goes further, and prescribes a maximum price of gas, existing shareholders may receive no dividend at all. Now the State, which justly condemns predatory acts in the case of a private concern, should keep its own hands clean. I am not prepared to say that the State should never do anything which may depreciate the market value of existing shares; but I do contend that the State should look all the facts in the face. A compromise between the claims of vested interests and the claims of the consumer may be necessary; but it should be a fair and reasonable compromise. No doubt it may seem unjust to compel consumers to pay a price for gas which represents an excessive rate of interest on costs of production. But the moral is that the State, through its various agencies, should keep a careful watch on all forms of monopoly. More especially, when it grants a franchise or privilege, it should do so under proper conditions. If it omits this precaution, it should make good the omission as soon as practicable; and, when it does act, it should act with a due regard to the interest of all parties. 
The statement just expressed brings me to the second view which was urged in the course of the passing of the New South Wales Act. That view is that the State, which has once granted a franchise, is precluded for ever from prescribing the conditions under which the franchise shall be exercised. Let us take the case of a gas company which is receiving $I_{5}$ per cent. on subscribed capital. Let us suppose, to take the case least favourable to my argument, that all the shares in the company are owned by investors who receive no more than 5 per cent. on the money which they have paid for the shares. Now it may well happen that some invention, a fall in the price of coal, or an expansion of business, may enable the company to increase its dividend on subscribed capital from I 5 per cent. to 30 per cent. if it maintains the same price to the consumer. Now, it is surely reasonable for the State to step in, in anticipation of such a condition of things, and to say, "You have made, in the past, I5 per cent. on subscribed capital. We are prepared to recognise the rights of the shareholders; but if costs of production are lowered, the consumer shall have a right to share in the gain. For the future, you shall only declare an increased dividend on condition of charging a lower price for gas. In proportion as you lower the price of gas, you may increase your dividend." I can see nothing unjust in such an attitude. However, justifiable or not, the attitude is adopted in the New South Wales Gas Act.

The more important sections are, in substance, 
I48 THE NEW SOUTH WALES GAS ACT, I9I2

as follows: Sections 3-I4 prescribe the means for ensuring a proper quality and pressure of gas supply.

Section I5 prescribes the standard rate of dividend. It allows the companies six months within which to capitalise their reserves, and permits them to declare dividends of Io per cent. on the total capital thus arrived at. On additional capital raised after the passing of the Act, the dividend is not to exceed 7 per cent.

Sections I6-I8 permit the companies to appropriate profits under specified conditions and within prescribed limits, for " A Special Purpose Fund," "A Reserve Fund," and "A Divisible Profits Account."

Section 20 provides for a standard price of gas at the rate of $3 s$. $6 d$. per 1,000 cubic feet. This price may be increased or decreased by proclamation, if costs of production should vary. Moreover, if the companies reduce the price of gas below $3 s$. $6 d$. they may, for every penny reduction in the price, pay an extra $\frac{1}{4}$ per cent. dividend.

Section 2I regulates the issue of additional shares.

Sections 22-23 provide for an annual statement, an examination and an audit of accounts. 


\section{CHAPTER XI}

"NEW PROTECTION" AND PRICE CONTROL: THE AUSTRALIAN SUGAR INDUSTRY

IN the chapter on the public control of prices, I referred to the interrelation between such control and Protection. The interrelation finds expression in Australia in the policy usually described as "New Protection." I propose in the present chapter to describe very briefly the development of New Protection, and to illustrate its character by a reference to the sugar industry.

\section{The Genesis of the New Protection}

The determination of the amount of a protective Import Duty implies a comparative estimate of conditions and costs of production in different countries. The State imposes a duty which is sufficient to enable the local industry to survive competition from abroad. Here, according to the traditional view, the responsibility of the State ends. The view assumes that the rate of wages, and the adjustment of profits among those who invest their capital in the various branches of the industry, may be left to the operation of "natural laws." If local wage earners do not receive the prevailing wage within the community, they will tend to seek other em- 
ployment. If producers do not receive an adequate return for the sums which they invest in a particular branch of the industry, they will gradually withdraw their capital. In an age of laissez-faire, these tendencies would be allowed to work out to their logical conclusions. In an age of democratic institutions, of social unrest, and of trusts and combines, men naturally turn to more direct and efficient means of securing distributive justice. While the situation is not peculiar to Australia, it invites there a readier response than in older countries which are more trammelled by their past, and by the greater complexity of the economic conditions with which they have to deal. Throughout Australia there is a growing conviction that a sound protective policy involves the protection, not only of industry, but also of the men and women engaged in that industry. The conviction, interpreted in terms of legislative policy, means that the imposition of an Import Duty should be accompanied by ancillary State action with a view to ensuring a greater social justice than could be hoped for if the distribution of the results of industrial enterprise were left to the unaided operation of natural laws.

At its inception, the policy of New Protection emphasised the need for maintaining standard conditions of labour. The failure of the competitive system to protect the worker is not peculiar to Australia or to protective countries; but the question of labour conditions, when viewed from the standpoint of the new-protectionist, appeared in a new light and invited 
a special form of remedy. It appeared in a new light because an Import Duty imposes a tax upon the community. Naturally, the community expects an adequate return; and it fails to secure this if, as too frequently happens, enhanced prices serve to enrich the few rather than to raise the living conditions of the many. Further, the question of labour conditions, when viewed from the New Protection standpoint, invited a special form of remedy. When a legislature imposes an Import Duty it may at the same time impose an Excise upon producers or manufacturers, and remit the Excise in all cases where the producer or manufacturer adheres to the standard of labour conditions which the legislature seeks to impose. Or, again, the legislature may confer a Bounty on production, while limiting the Bounty to producers who adhere to an approved standard of labour conditions.

The importance of New Protection, as a means of protecting wage earners, has been diminished both by judicial decisions which put a restrictive interpretation upon the constitutional powers of the Commonwealth Parliament, and also by the development of Wages Boards and Courts of Industrial Arbitration which are not limited to protected industries. But the progress of events is serving to bring out the implications of the New Protection and to give to the policy a much wider application. The development of various forms of monopoly affords an apparent justification for an appeal on the part of producers and consumers to the sheltering arm of the civic power. The existence of a trust at any stage in 
the progress from the raw material to the consumable commodity imperils the profits of the producers or manufacturers at all preceding stages. The trust will be tempted (and it will probably succumb to the temptation) to buy as cheaply as it can, subject to no restraint save the fear of starving suppliers out of existence.

In Australia the primary producer is most industries needs no protective Import Duty. But where protection is necessary, as in the case of tropical industries which have to meet the competition of coloured labour abroad, conditions which imperil the profits of the primary producer afford special grounds for the intervention of the State. (I) The concentration of the population in capital cities has already given grave cause for alarm. Any scheme of protection which, while protecting the manufacturer, leaves "the man of the land " at the mercy of a business combination, imperils the virility of the people as well as the financial stability of the Commonwealth. (2) In Australia, the cost of living and the cost of production generally are high. The mere fact that an Import Duty may be necessary in order to enable a primary producer to survive the competition of the world's markets implies a power on the part of a local trust to exploit the producer without fear of any disturbance in the way of external competition. The producer must sell his product to the manufacturer if he is not to export at a heavy loss. (3) In Australia, the wage earner is protected both by the limited supply of labour in relation to demand, and, in an increasing degree, by legislative, judicial and administrative 
action for the insurance of a living wage. If the primary producer receives a low price for his product, he is unable to pass on his losses to the wage earner. He may be compelled to pay a fair wage while he enjoys no guarantee, in fact or in law, of a fair price for his commodity.

I believe that the progress of events is bringing home to the Australian electorate certain consequences which were really implicit in the New Protection as first formulated. Those consequences are that a legislature which imposes an Import Duty with certain objects in view-whether the establishment of an industry under standard conditions of life, the settlement of tropical areas, or any other purpose-must assume, if need arise, the further responsibility of ensuring that the objects for which the duty is imposed are achieved. The need for State action may not arise where competition operates with reasonable efficiency. Where it does not so operate, the State must be prepared in one way or another, by public control of prices or by some other device, to shoulder the grave responsibility which the development of industrial organisation imposes upon it.

\section{The Sugar Industry}

The history of the Sugar Industry in Australia affords an example of, if not a justification for, the progress of Australian thought along the lines which I have indicated. In the earlier stages, the objective of protective policy, so far as it was in existence, was the maintenance of an industry for which the soil and climate of the Queensland 
littoral seemed peculiarly adapted. Coloured labour from the Orient or the Pacific Islands was freely employed, especially in the fields. The industry, however, entered upon a new phase with the federation of the Australian Colonies, the growth of a national spirit, and the widespread acceptance of the policy of a White Australia. The able-bodied Kanakas from the Pacific Islands were deported; and the Parliament of the Commonwealth devised a complicated system of Bounty, Excise, and Customs Duty with a view to promoting the exclusive employment of white labour and the payment of a standard rate of wage. The Customs Duty on cane sugar was fixed at $£ 6$ per ton. The refiner (or the miller, where the sugar was sold unrefined) paid Excise at the rate of $£ 4$ per ton. The grower received a Bounty at the rate of $£ 3$ per ton of the sugar-producing contents of the cane, subject to two conditions: he must employ only white labour, and he must pay approved rates of wage. The system revealed the New Protection in its earlier phase. That phase, as we have seen, concerned the wage earner. But for some time the grower has contended that he receives a quite inadequate price for his cane, even when the Bounty is added. Assuming the contention to be just, one obvious remedy would have been to increase the Bounty. The remedy, however, had the demerit of being expensive. Nor could its adequacy be assumed in the absence of some guarantee that the miller did not make the increase of the Bounty a pretext for lowering his price for the cane. 
The problem of protecting the grower derived a special importance owing to apprehensions of Asiatic invasion. The necessity for defence, no less than the ideal of a white continent, pledges Australia to discover a means of settling tropical or semi-tropical areas. For the purposes of settlement, the protection of the grower is a matter of the first importance. Some doubts have existed in the past as to the suitability of tropical areas for white settlement. But the experience of Queensland lends no countenance to such doubts, provided there be a reasonable adaptation of diet, home conditions and modes of life. This remark applies even to the Queensland littoral. But beyond the littoral, there are vast areas which admit of a very varied cultivation, and enjoy, owing to their elevation above sea level, a climate of undoubted excellence. Hence the settlement of the littoral, apart from its intrinsic advantages, affords a stimulus to the opening up and settlement of the Hinterland. In view of these facts, the protection of the grower on the sugar-fields assumes a national importance. The policy of a White Australia is involved in two ways: (I) Unsettled areas in the northern parts of Australia are difficult to defend; and they invite, if they would not justify, the predatory invasion of the Asiatic. (2) The defence of Australia now depends, and for a long time to come must continue to depend, upon external support. The circumstance calls for an effective demonstration that the ideal of a White Australia is no mere policy of the dog-in-the-manger order.

The preceding argument discloses a revolution 
in the purposes for which the protection of the sugar industry exists. The maintenance of an industry, and even the assurance of standard conditions of labour, are of minor importance as compared with the great question of settlement and defence. Unfortunately, the grower on the sugar plantation, who represents the most important branch of the sugar industry for the purpose of settlement, has also been the person who made the least profit under the scheme of protection evolved by the Commonwealth Parliament. The circumstance calls for explanation. While the wage earner finds some, though an inadequate, protection in the Bounty Regulations, the grower is a prey to various forms of monopoly or quasi-monopoly. The raw sugar mills, generally speaking, do not compete against one another as regards the price which they pay for the cane; and the situation is complicated by the fact that the millers are themselves in the grip of the refiners owing to the predominating control of the Colonial Sugar Refining Company, popularly known as the C.S.R. The Company does not, within Australia, engage in growing cane; but it owns mills for the manufacture of raw sugar, which deal with over a third of the total Australian output; and its refineries, for the conversion of raw sugar into refined, deal with about threefourths of the Australian output. The Company does a large business in Fiji and New Zealand; and it imports from abroad such supplies of foreign sugar as may be necessary to meet the Australian demand. Sometimes represented as a model of financial piety, at other times spoken 
of as an "Octopus," the Company is in reality neither the one nor the other. It is a business concern which accepts traditional business ethics. It differs from other concerns, not in its standards of business morality, but in its power to profit by those standards. By virtue of its high efficiency, its vast capital, and its dominating position in the Australian refining industry, it controls within certain limits the prices of refined sugar, raw sugar and sugar-cane respectively.

As regards refined sugar, the despotism of the Company is subject to certain real or apparent limitations-the existence of a rival refinery at Millaquin, importations from abroad, and the collateral competition of mill white sugar. (I) The refinery at Millaquin is a negligible factor. It is a relatively small concern, which knows its own business too well to attempt to cut prices. Incapable of waging a war of competition, it prefers a docile adherence to the scale of prices fixed by the dominant company. (2) The importations from abroad undoubtedly exercise a restraining influence. But that influence operates to mitigate, rather than preclude, the exploitation of consumers. The importer has to pay a high Import Duty; and the control over the market by the C.S.R. is further enhanced by the superior facilities for marketing which accrue to the large business, and by the policy of granting special discounts to purchasers on the express condition that they buy only Australian produced sugar. (3) The collateral competition of mill white sugar affords, at present, a very inadequate protection to the consumer. The difference between the cost of 
production of mill white and refined sugar respectively, is not sufficiently great to enable the manufacturer of the former commodity to put it on the market at a price low enough to attract the ordinary consumer. Refined sugar looks better; and the ordinary consumer, whether from a sense of beauty or a desire to appear respectable, prefers to pay a slightly higher price for the more attractive article. In the net result it may be said that the Colonial Sugar Refining Company has a monopolistic control over the price of consumable sugar in Australia. What actually happens is that the Company fixes prices subject to two main qualifications. The price must not be so high as to encourage large importations of refined sugar by other persons or companies. On the other hand, the price must be at least high enough to admit of refining profits while paying for raw sugar a price sufficiently high to avoid squeezing producers of the raw material out of existence. ${ }^{1}$ The fear of potential competition, a factor to which many American writers attach great importance, is negligible within an area where (I) a powerful company is already within possession of the local market, (2) the local market is too limited to give a competitor the chance of survival which he enjoys in the case of a rapidly expanding market, and (3) the prospects of any substantial export trade are chimerical.

The monopolistic control of the C.S.R., as purchasers of raw sugar, is still more complete. The foreign market price is so low as to preclude

${ }^{1}$ See "Report of the Royal Commission on the Sugar Industry," I912, p. 38 . 
the possibility of an export trade; and the only local rival to the Company for the purchase of raw sugar is the Millaquin Refinery, which, for reasons already stated, accepts the schedule of prices imposed by the larger concern.

As regards the prices paid for sugar-cane, raw sugar mills, whether belonging to the dominant company or not, do not as a rule compete against one another. Sugar-cane is not a commodity which can be carried from mill to mill. The mill which is nearest at hand, and is connected with the adjacent fields by tramlines, enjoys within its area of operations a monopolistic power of fixing prices for the cane. Where mills do come into some sort of competition with one another, the competition is apt to be rendered nominal by the easy device of agreements among the millers which limit the price of cane or define the areas of supply.

Theoretically, the growers might bring pressure to bear on both millers and refiners by a threat to desert the industry; but the threat would be little more than bluff. The growers have already invested their all in their farms. They have built their homes; they have cleared their lands ; and they have no alternative form of cultivation to which they can turn in self-defence. Nor are they able to secure justice by collective bargaining. They are an unorganised body; they have less staying power than the millers; they are in many cases indebted to the millers for advances against crops or otherwise ; and they are frequently under an agreement with the millers for a term of years. Finally, although a large number of the mills are 
owned by growers, the growers who are not shareholders are at the mercy of the growers who are. Even where both classes of growers receive the same price for their cane, the arrangement may be a mere matter of book-keeping. The shareholder who acquiesces in a low price for his cane finds a consolation in the expectation of the profits which he may hope to realise as miller.

I have just given some facts taken from the evidence of the recent Sugar Commission. The following questions and answers, taken from the evidence of the representative of the C.S.R., express the situation in brief :

"Question 26994. Do you take the position that your company, though it enjoys the power to fix prices for sugar-cane, raw sugar, and refined sugar, respectively, exercises that power with reasonable regard to other branches of the industry?

"Answer. Unquestionably; I can say quite definitely we sometimes maintain the price on an occasion when I myself was inclined to reduce it, in order that the mill-owners, from whom we purchased sugar in Queensland, might get the advantage. Of course, we derive some advantage ourselves too.

"Question 27558. In your endeavour to do the fair thing to the other branches of the industry, what guarantee is there that you will do it? Not merely as regards your mills, but at most of the mills in Queensland, the cane-grower must take the price offered or cease growing cane. That is his alternative? 
"Answer. Are we not bound to assume the whole community must respect the Mosaic law ?

"Question 27559. I do not know that the assumption would be a safe one?

"Answer. I do not see how I can say any more than that. We regard the Mosaic law as binding on us. I could not say any more." '

Upon this and other evidence, the Report of the Sugar Commission remarks: "In the preceding argument we have been chiefly concerned to show how inadequate is the operation of competition in the sugar industry to insure a reasonable distribution of profits among its various branches. The refiners dictate prices to the millers; the millers dictate prices to the growers. Such dictation is not necessarily inconsistent with a reasonable distribution of profits, presuming the refiners and millers exercise the power which they possess subject to the injunction to love one's neighbour as oneself. A priori, an expectation that such an injunction would be observed in the conduct of business concerns would imply a more sanguine view of human nature than can be claimed by Your Commissioners. We think it would be more safe to assume as typical the attitude of Mr. John Drysdale, of Pioneer Mill, Lower Burdekin:

"Question 7927. Dealing with the last five years, I must still press you to put a figure on what you think, having regard to the nature of this business and its present position, would be a fair interest on your capital ?

"Answer. As much as you can get.

1 "The Report of the Royal Commission on the Sugar Industry," p. 4I. 
"Question 7930. What would you put it down at?

"Answer. Fifteen per cent., or more, if you could get it."

Turning from a priori probabilities to actual facts, the Report of the Commission indicates that, while the millers and refiners made high profits, the return to the grower on his capital and effort is wholly inadequate. Hence a grave situation. For, while the growers, millers and refiners represent the great bulk of the capital which is invested in the sugar industry, the relative importance of these classes from a national point of view must be determined, as I have already remarked, by reference to the extent to which they severally contribute to the great problem of the settlement of the tropical or semi-tropical areas. Most of the refineries are established in temperate regions. Mills may, and in a number of cases do, represent the capital of persons living in the temperate regions. Wage earners come and go. The growers, as a class, are tied to the lands. It follows that they possess a unique importance and a special claim to legislative protection.

I do not think that the situation calls for rhetorical attacks upon the Colonial Sugar Refining Company. I believe that the Company in question can claim with justice to have endeavoured to exercise its great powers with prudent moderation. But this very fact makes the Company a significant example of the need for external control over monopolistic concerns. Even when such concerns set out to do the fair thing, their view of what is a fair thing is so affected by considerations 
of self-interest that exploitation assumes the guise of legitimate enterprise, and injustice to producers, consumers or employees is attributed to the operation of natural laws for which the individual or company claims to be irresponsible. In such a connection, natural laws are apt to be a mere euphemism for buying cheap and selling dear. Where no monopoly exists, competition may secure, approximately and in the long run, that the prices paid or given shall be reasonable. But where a monopoly is in the field, the appeal to natural laws may well be an appeal to brute force -an endeavour to discover an ethical justification for the exercise of the primitive instinct of exploitation. The Royal Sugar Commission was unanimous in its finding that the profits of the sugar industry were very unequally divided among its various branches, and that in the general result the growers suffered. The evidence taken before the Commission showed that the C.S.R. paid the employees in its mills, which were removed from the area of competition, the wage of twenty shillings a week and found, whereas, in its other mills, it paid thirty shillings a week and found. The evidence also went to show that the Company, at least on many occasions, if not as a general rule, charged the consumer higher prices for refined sugar than was necessary to ensure reasonable profits to the Company.

III. Recommendations of the Commonwealth Royal Sugar Commission

Bounty and Excise. The Royal Commission recommended the abolition of the Bounty and 
Excise system for various reasons, of which three deserve mention here. (I) The system has failed as a means of promoting a just apportionment of profits among the various branches of the industry. So long as prices are subject to monopoly control, it is impossible, by giving at one stage in the process of production and manufacture, and by taking at another stage, to determine to any adequate extent the profits of different parties engaged in the industry. (2) The system, as a means of securing a just wage to employees, has been partial in its operation, protecting only the employees of the growers. (3) The purposes of the Bounty Regulations may be secured, and in the opinion of the Commission should be secured, by direct legislative action on the part either of the Commonwealth or the States.

Employees. The Report recommends the payment of a minimum wage to employees of eight shillings for a day of eight hours, together with a number of other conditions as to overtime, etc. The Report assumes that the existing Australian machinery is, or may be made, adequate for the purpose of carrying the above recommendation into effect.

Millers, Growers, Consumers. For the protection of millers, growers and consumers, the Report makes certain recommendations which demand a more detailed consideration, since they involve the necessity for devising new machinery.

According to the evidence tendered to the Commission, the millers received $£ 97 s .6 d$. per ton of raw sugar of 94 net titre standard when the refined article was selling at $£$ Ig. As the selling 
price of refined sugar rose, the price for raw sugar also rose at the rate of $I 8 s$. in the pound. The refiners fixed the sliding scale. - The Commission recommends that the sliding scale shall be fixed in the future by the Inter-State Commission on a basis of refining costs, including therein a reasonable interest on capital and a due allowance for depreciation.

To ensure that the grower shall receive a fair price for his cane was a more difficult matter. Differences of conditions between mills as to ownership, locality, milling capacity and available sources of supply, and the differences as to quality and condition of cane, make a single sliding scale price unworkable. The Report recommends that the price for cane be fixed for each mill on the Wages Board system; that the owners of the mill elect a representative; that the growers (who are not owners of the mill) appoint another representative ; and that the Chairman if not a member of, shall be appointed by, the Inter-State Commission. It is also recommended that the board so constituted fix the price for cane on a basis which will allow to the miller fair manufacturing profits, proper maintenance and proper writing off for depreciation. The board may adopt the system of payment according to the sugar content straight out, or according to the sugar content varying in conjunction with the price of refined sugar, or according to the total average results of the mill straight out, or according to those results taken in conjunction with the price of refined sugar, or according to any other scheme which commends itself to the board as likely to be 
just to all parties under the circumstances of each case. It may stipulate what reductions shall be made for damaged cane. It may also provide for a revision of the award in case of a surplus in the Australian output of raw sugar which should result in the necessity for export at a loss, and a diminution in the price received by the mill for its raw sugar. The advantages of the foregoing scheme are briefly summarised in the Report. (I) Prices would be fixed, not by one party to a bargain, but by an authority representative of both parties. (2) An increased community of interest would exist as between millers and growers, since the growers would have a direct interest both in the efficiency of the mill and in maintaining supplies. (3) A new stability would be given to milling and growing interests. (4) The protection afforded to the grower would promote those national purposes of settlement and defence which constitute the ultimate justification for the protective policy with regard to the sugar industry. (5) The consumers would know that the burden placed upon their shoulders was not resulting in the undue enrichment of monopolistic concerns, but in the achievement of national ends.

Consumers. I have spoken of the recommendations of the Commission for the protection of employees, millers and growers. As regards consumers, the Report points out that, where the determination of the price of a protected commodity is subject to trust control, price fluctuations are likely to be less marked in the home market than abroad. The trust will be able to maintain local prices when foreign prices are 
usually low, at any rate for some time. On the other hand, when foreign prices are unusually high, the trust will probably not take full advantage of the rise for fear of inviting a reduction of the Import Duty. So far, the trust may be regarded as a beneficent institution; it steadies prices. But its influence is more likely to be exerted in the direction of maintaining high prices to the consumer than in the direction of maintaining fair prices to the primary producer. The position may be stated as follows: (I) When foreign market prices are abnormally high, the consumers within the protected area are burdened with prices which are higher than is necessary for the purposes of protecting the local industry. (2) When foreign market prices remain low for any length of time, then, assuming the fixed Import Duty to have been assessed in the first instance at a not unnecessarily high figure, the local industry is carried on at a loss. The loss may not be equally shared between all branches. The larger business concerns will probably throw the loss on the primary producer. But even supposing the loss to be shared all round, the condition of things is unsatisfactory. The larger business concerns may be able to survive as a result of profits accumulated when foreign market prices were high. The smaller concerns, and the primary producers more especially, are threatened with extinction. This is especially the case if the period of low foreign prices should chance to be coterminous with a period when, for local reasons, the local industry is in a bad way.

The Report recommends that, in order to 
protect consumers when foreign prices are abnormally high (as well as to protect the local industry when foreign prices are abnormally low), the Customs Duty should fluctuate with foreign market prices, falling as those prices rise, rising as those prices fall. It is suggested that the amount of the duty should be the difference between foreign market price of refined sugar (as declared from time to time by the Department of Customs) and a "standard price" for Australian refined sugar. It is also suggested that the standard price should be fixed on the basis of not less than $£ 2 I$ IOS. a ton as representative of Australian costs of production of refined sugar of IA grade.

The mode of arriving at an estimate of foreign market price, the periods at which that price should be declared, and the necessary addition to or deduction from the $f^{2}$ I IOs. (as representative of Australian costs of production) in computing the " standard price," are important details which were left by the Commission for the consideration of the Commonwealth Administrative service. The existing preference for a fixed Import Duty may be taken to indicate serious difficulties in the practical application of a fluctuating Import Duty. Assuming the difficulties to be insuperable, the protection of the consumer would depend upon the effective application of the policies of monopoly control to which I have referred in previous chapters-Publicity and the Legal Regulation and Administrative Supervision of Competition. The consumer would sometimes pay too much for his sugar. Sometimes he would pay too 
little. In the long run, he should obtain it at a price fairly representative of local costs of production. Still, for reasons already stated, and more especially for the purpose of protecting the primary producer, a fluctuating Import Duty is desirable if it be practicable. I believe that it would be practicable, notwithstanding precedents which have been quoted to be contrary. Those precedents date from times when the conditions were different from those which exist to-day. For, whatever difficulties may exist in the application of a fluctuating Import Duty to protected industries generally, there are at least two reasons for believing that those difficulties might be overcome in the case of the Australian sugar industry. In the first place, where an industry is subject to the control of a trust, the virtual elimination of internal competition implies the possibility of an approximately uniform selling price throughout the whole of the local market. In the second place, where a local industry is subject to trust control, and where there exists an administrative body such as the Inter-State Commission, there exists the possibility of co-operation between the trust and the public administrative body. Such co-operation is in actual existence to-day in Germany. Why should it not exist in Australia? And, assuming it to exist, many things would be possible which now seem to many impossible. In my opinion, a fluctuating Import Duty is one of them.

\section{Recent Legislation}

The Report of the Royal Sugar Commission was presented on December 2, I9I2. The Common- 
wealth Parliament has now abolished the Bounty and Excise system, and has created an Inter-State Commission of which the functions are described in the next chapter. The Parliament of Queensland has passed legislation for the protection of employees in the various branches of the sugar industry, and also for securing the purposes of the Bounty Regulations relating to the exclusion of coloured labour. The same Parliament has also had under consideration the problem of protecting the growers. A Bill was introduced towards the close of I9I3, and passed its second reading, for the creation of Cane Price Boards. Although the Parliamentary session was too near its close to allow of time for the Bill to go into Committee, the Bill appears to me to deserve special consideration. I give a copy of the Bill in Appendix A.

While the foregoing remarks show that the Report of the Royal Sugar Commission has not been without useful results, and while further legislation along the lines indicated in the Report may be confidently anticipated in the near future, the immediate value of the Report is rather to be found in the publicity given to existing conditions. It is not merely that public opinion has now some definite material upon which to work. That is undoubtedly true and important. But I believe that it is also true that something has been done to quicken the business conscience of large industrial concerns. As one observer pertinently if irreverently remarked, the Report had gone some distance towards endowing with a soul the "soulless corporation." I ought to add, in order to make this chapter complete, that 
one member of the Commission dissented in important respects from the recommendations of the Report. I should also add that these recommendations have been subjected to criticisms in the Press and elsewhere. Most of these criticisms, however, if they did not relate to matters of detail, were of the kind likely to occur either to a socialist who is not content with anything less than nationalisation, or to the individualist whose faith in laissez-faire triumphs over any consciousness of the difficulties which result from the existing tendency to eliminate or qualify the operation of competition. I have endeavoured to anticipate such criticisms in the argument of preceding chapters. 


\section{CHAPTER XII}

\section{CONCLUSION}

\section{Summary of Preceding Argument}

In the earlier part of the present work, I expressed the opinion that the solution of the problems of monopolistic capitalism demands an extension of public control. I have endeavoured to indicate the forms in which this extension can be effected with the least disturbance of industrial conditions consistent with the achievement of the purposes in view.

While admitting the great value of publicity and the legal regulation and administrative supervision of competition, I have pointed out that these policies are unlikely to prove to be universally effective as a means of preserving or restoring competitive industry. In particular, monopolies in naturally non-competitive industries, monopolies which have acquired their power on the sole basis of the efficiency of large scale organisation, and many monopolies based on honourable understandings, call for forms of public control which involve a more serious departure from laissez-faire policy. While the abuses of a persistent monopoly of one or other of the kinds just mentioned may be checked by dread of public disclosure or the fear of potential 
competition, something more is necessary if the community, and various classes of the community, are to enjoy a reasonable immunity from predatory exploitation. Hence the need for further policies of monopoly control-public ownership and the public regulation of prices. Both these policies are, in my opinion, an essential part in any comprehensive scheme of monopoly control. I have stated my reasons for believing that, as between the two policies, the preference should generally be given to the public regulation of prices on the ground that private ownership, even when subject to proper regulation by public authorities, is likely both to be more efficient than public ownership, and also to involve a less serious extension of public responsibility. But in the case of any particular monopoly with regard to which the need for either form of control becomes apparent, all the circumstances which exist in the particular industry concerned must be taken into consideration.

In various chapters, I have referred to the necessary machinery for giving effect to the various policies just indicated. The machinery includes legal control, administrative control and public ownership. As between these three forms of governmental action, the reader will have seen that I attach most importance to administrative control. While the need for this control is especially apparent in the case of the public regulation of prices, it also exists with respect to publicity and the regulation of competition.

So far as I am aware, Australia may claim to possess the nearest approach to an administrative 
body capable of giving practical effect to the various policies to which I have referred. An Act of I9I2 creates an Inter-State Commission which is designed, inter alia, to discharge the various functions of the State in relation to the prevention, regulation and control of monopolies. I propose to give a brief account of this Act. I shall then consider how far, and in what respects, the Commission created by the Act falls short of the ideal administrative body which I have in mind as necessary to the realisation of an adequate scheme of monopoly control.

\section{The Commonwealth Inter-State CoMmission ACT, I9I2}

The Australian electorate is divisible into two main groups of conservative reformers and socialists. The conservative reformer advocates the extension of legal or administrative control over private-owned industry. The socialist advocates public ownership. These classes, however, have certain views in common. The socialist who extols public ownership has often in view an ultimate goal rather than a policy for immediate application. In any case, both constitutional limitations and practical necessities compel him to face the question of the public regulation of private-owned industry, pending its nationalisation. It follows that both the conservative reformer and the socialist are deeply interested in proposals for giving effect to that regulation. Both regard with favour the Inter-State Commission Act, although they differ in their views 
of the ideal functions of the Commission which that Act creates.

The Inter-State Commission Act was passed under the authority of Section ror of the Constitution of the Commonwealth. That section directs that there shall be an Inter-State Commission with such powers of adjudication and administration as the Parliament deems necessary for the execution and maintenance of the provisions of the Constitution relating to trade and commerce, and of all lares made thereunder. By Section $5 \mathrm{I}$ (I) of the Constitution, the Parliament has power to make laws for the peace, order and good government of the Commonwealth with respect to trade and commerce with other countries and among the States. These two sections indicate in a general way the ambit of authority of the InterState Commission. The Commission has large powers of investigation and adjudication; and it can even exercise, in direct or indirect ways, a control over prices. Time alone can show whether it will exercise these powers wisely; no one can doubt their range and importance. The Commission is a great social experiment.

Constitution. The Commission consists of a Chief Commissioner and two other members, appointed by the Governor-General of the Commonwealth. It is a corporate body and a court of record.

Tenure of Commissioners. The salary of the Chief Commissioner is $£ 2,500$ per annum. The salary of the other Commissioner is $\ell^{2,000}$ per annum. Each member holds office for a term of seven years, but is eligible for reappointment. 
The Governor-General may suspend any Commissioner for misbehaviour or incapacity; but the Commissioner must be restored to office unless each House of Parliament passes an address praying for his removal on the grounds of proved misbehaviour or incapacity.

Investigations. The Commission is to investigate from time to time matters affecting production, trade, industries, manufactures, external markets, tariffs, prices, profits, wages, industrial conditions, foreign shipping, export bounties, immigration, river questions, and other matters referred to the Commission by resolution of either House of Parliament.

Conduct of Investigations. The Chief Commissioner may summon any person to give evidence and to produce any books, documents or writings in his custody or control. Witnesses may be examined upon oath. If a witness fails to appear, a warrant may be issued for his apprehension. If a witness fails to appear without reasonable excuse, or fails to produce required documents, books or writings in his custody or control, he is guilty of an offence. Penalty: Five hundred pounds. But a witness may not be compelled to disclose any secret process of manufacture or to produce documents, books or writings which are not relevant to the investigation. The Commission may take evidence in public or private; and it may publish such information relating to any matter investigated by it as it thinks fit.

Inter-State Traffic. The Act declares that all rates fixed by a common carrier in respect of 
Inter-State Commerce shall be just and reasonable ; and that no common carrier, State railway or State authority shall be guilty of undue preference in respect of Inter-State commerce. The enforcement of these provisions is within the especial province of the Commission.

Judicial Powers. The Commission, in the exercise of its powers of adjudication, is a court of record. It may call in the aid of one or more assessors, who must be persons of technical knowledge and shall receive such remuneration as it directs. It has jurisdiction to determine upon acts, omissions or discriminations in contravention of the Act, or of the provisions of the Constitution relating to trade and commerce, or of any law made thereunder. Complaints may be made to the Commission by public authorities or private parties; and the Commission may hear and determine the matter of the complaint according to equity and good conscience, and in such a manner as to do justice to the parties. It may also act on its own motion without waiting for complaint to be made. It may grant such relief as it deems proper, award damages, issue injunctions, fix penalties for disobedience to its orders, and may prescribe future action, as by naming a maximum or minimum rate for certain services. It may declare void any State regulation in pursuance of which anything is done or undone in contravention of the Act, or of the provisions of the Constitution relating to trade or commerce, or of any law made thereunder. No appeal lies from the Commission except an appeal to the High Court on questions of law only. The High Court, 
on hearing of an appeal, may draw all such inferences as are not inconsistent with the facts expressly found and are necessary for determining the question of law. The operation of any order of the Commission is not to be stayed, pending the decision of an appeal, unless the Commission or the High Court otherwise directs.

Reports. The Commission is required to make each year a report of the work done, the investigations made, and the proceedings taken, together with any recommendations as to future legislation which it may think fit. It may also publish information relating to any matter investigated by it.

Miscellaneous. Any person who is, in any manner, guilty of any wilful contempt of the Commission is guilty of an offence. Penalty: One hundred pounds, or imprisonment for three months. Each Commissioner, in the exercise of his duty, has the same protection and immunity as a Justice of the High Court. The GovernorGeneral may make regulations, not inconsistent with the Act, for giving effect to it.

\section{The Inter-State Commission AND MONOPOLIES}

From the preceding summary, it will be apparent that the Commission created by the Commonwealth Act has to discharge a number of functions which have little or no connection with the problems involved in the prevention, regulation or control of monopolies. Taking into consideration the importance of those problems, and their 
increasing complexity, there is ample justification for the creation of a special body to deal with them. The expense to the community is a negligible factor when viewed in relation to the importance of the services to be rendered.

On the other hand, while the Commission has too many functions to discharge, it lacks some of the powers which appear to me to be necessary to an adequate system of administrative supervision. The Commission should be empowered to require every business which it deems to be a monopoly to forward an annual report showing in reasonable detail its assets, liabilities and profits. The power of the Commission to call in aid expert assessors should not be limited to judicial proceedings. In the case of any appeal from the Commission, in the exercise of its judicial powers, the declaration of the Commission as to what is unfair competition, or public detriment, etc., should be deemed prima facie valid so as to shift the burden of proof on the appellant where this is not already the rule of law.

The remarks just made have a specific reference to the policies which I have described as publicity and the regulation of competition. The Commission created by the Commonwealth Act may also recommend the nationalisation of an industry. An extension of its power with respect to this subject matter is, for many reasons, not desirable. As regards the public contro! of prices, however, we are on more difficult and debatable ground, both as regards legal and constitutional questions and as regards questions of political expediency. Obviously, the Inter-State Commission may recom- 
mend the Legislature to fix prices by law within the ambit of its authority. It has also certain powers with respect to naming prices the nature of which I shall explain directly. Further, the Commonwealth Parliament, which enjoys plenary powers within the ambit of its authority, may pass a law empowering the Commission to exercise a direct control over prices for services or commodities in a particular industry subject to Commonwealth control.

In my opinion, however, the Inter-State Commission has not all the powers which are necessary in order to give effect to the public control of prices. What are those powers? Comprehensively but briefly stated they are as follows:

(I) To declare an existing scale of prices unreasonable-such declaration in the case of any judicial proceeding against a trust or combine to be prima-facie proof that the prices are unreasonable.

(2) To call upon a monopoly to revise its prices.

(3) To summon representatives of various branches of an industry for the purpose of coming to some agreement with respect to prices.

(4) To recommend legislation for the control of monopoly prices in a particular industry (cf. supra, Chapter X, "The New South Wales Gas Act," and Appendix A, "The Queensland Cane Price Boards Act").

(5) To fix for a period of time maximum or 
minimum prices, either straight out or on a sliding scale, and either absolutely or conditionally.

The justification for such powers, and the conditions under which they should be exercised, have been discussed in earlier chapters. I may, however, repeat my opinion that the powers should be regarded as powers to be held in reserve, and only to be exercised in the case of established monopolies which are deemed to be guilty of exploitation. While the difficulties of fixing prices in any industry would act as an adequate deterrent upon an extreme exercise of the power last mentioned in the above list, the mere possession of the power would go far to remove any need for its exercise.

The above powers of price control are not wholly denied to the Commonwealth Inter-State Commission. Section $I 8$ of the Act prescribes that all rates fixed by common carriers shall be reasonable. By Section 2 I no common carrier shall (a) make any undue preference to any person, State, locality or description of traffic, $(b)$ subject any particular person, State, locality or description of traffic to undue prejudice or disadvantage. By Section 33, if it appears to the Commission, on the hearing of any complaint, that anything has been done or left undone in contravention of the Act, or of the provisions of the Constitution relating to trade and commerce, or any law made thereunder, it may declare the thing which the party is required to do, or not to do, in order to bring himself into conformity with the Act, 
etc. For this purpose, it has, inter alia, the power-

(a) To name a maximum rate for any service.

(b) To name both a maximum and a minimum rate when that is necessary to prevent an unlawful preference or discrimination.

(c) To name a maximum or minimum of difference between two rates when that is necessary to prevent an unlawful preference or discrimination.

Along with Section 33, we must read the various sections of the Acts for the Preservation of Australian Industries. Those Acts are laws passed under the authority of the Commonwealth to legislate with respect to trade and commerce. Their enforcement, therefore, comes within the scope of the duties of the Inter-State Commission. As stated in an earlier chapter, they are primarily directed against unfair competition, etc.

The power to prescribe future action given under Section 33 of the Inter-State Commission Act, however, is not a power to fix prices, but to declare what prices will bring a party, charged with an offence, into conformity with law. Apart altogether from constitutional limitations upon the Commonwealth sphere of control with which I am not now concerned, the power given by Section 33 is subject to two serious limitations. (a) There is no general law to the effect that monopoly prices for a commodity or service shall be reasonable. (b) Even if there were such a law, action of the Inter-State Commission would be subject to appeal to the High Court. When it 
is a case of deciding whether a party has or has not been guilty of an offence, and so become subject to punishment, there appears to me a strong reason for allowing an appeal to the High Court-a reason which does not exist when the order of the Commission is purely prospective. In the latter case, it appears to me that the structure of the Commission, and its more intimate acquaintance with the conditions of trade and commerce, are strong arguments for disallowing any appeal from its decisions save to the "High Court of Parliament." 


\section{APPENDIX A}

A BILL TO PROVIDE FOR THE CREATION OF SUGAR CANE PRICE BOARDS, AND TO REGULATE THEIR POWERS AND DUTIES, AND FOR OTHER PURPOSES CONSEQUENT THEREON

[Initiated in Committee, r6th October, rgr3;-LIEur.-CoL. RANKIN.]

$\mathrm{BE}$ it enacted by the King's Most Excellent Majesty, by and with the advice and consent of the Legislative Council and Legislative Assembly of Queensland in Parliament assembled, and by the authority of the same, as follows :-

\section{Short Title}

1. This Act may be cited as "The Sugar Cane Price Boards Act of r913."

\section{Interpretation}

2. In this Act, unless the context otherwise indicates, the following terms have the meanings respectively set out against them, that is to say,-

\section{Award}

"Award "- The award of a Board, or of the Court under this Act; 


\section{APPENDIX}

\section{Cane Supplier}

"Cane Supplier"-Any person, company, corporation, firm, or association selling and supplying sugar cane to a sugar mill for the purpose of its being treated and manufactured into sugar;

\section{Court}

"Court"-The Industrial Court constituted and acting under "The Industrial Peace Act of I9I2" ;

\section{Minister}

"Minister"-The Minister of the Crown for the time being charged with the administration of this Act ;

\section{Owner of a Mill ; Owner}

"Owner of a Mill"; "Owner"-Any person, company, corporation, firm, or association owning or having the control of a sugar mill: the term, where necessary, includes the manager or managing director or other person controlling the business of a mill: the term does not include the corporation of the "Treasurer" created under and for the purposes of "The Sugar Works Guarantee Acts, I893 to I908," or "The Sugar Works Act of IgII," or any officer of such corporation;

\section{Prescribed}

"Prescribed"-Prescribed by this Act;

\section{Registrar}

"Registrar" - The Industrial Registrar appointed and acting under "The Industrial Peace Act 


\section{APPENDIX}

of I9I2": the term includes a deputy or assistant Industrial Registrar ;

\section{Regulations}

"Regulations"-Regulations made under this Act ;

Sugar Cane Price Board; Board

"Sugar Cane Price Board"; "Board"-A Sugar Cane Price Board created under and for the purposes of this Act ;

\section{Sugar Mill ; Mill}

"Sugar Mill"; "Mill"-A sugar mill to which sugar cane is sold and supplied for the purpose of being treated and manufactured into sugar:

This Act

"This Act" includes Regulations made under this Act.

\section{Creation of Boards}

3. Sugar Cane Price Boards may be created for the purposes hereinafter set forth.

\section{Application}

4. (I.) Before a Board is created, application therefore shall be made to the Minister.

(2.) Such application may be made in the prescribed form by-

(a) The owner or owners of any particular mill or mills; or

(b) Any number of growers of sugar cane, not being less than two-thirds of those growers who supplied sugar cane during the year then last 
past to the particular mill or mills for which the Board is required.

Such application may be made not later than the thirty-first day of January in any year.

(3.) Upon the receipt of an application for the creation of a Board, the Minister may cause to be made such inquiry into the matter as he thinks proper, and may recommend to the Governor in Council that a Board shall be created in accordance with the terms of the application or with any such modification thereof as he thinks necessary.

(4.) Thereupon the Governor in Council may, by Order in Council, made not later than the first day of March next succeeding the application, create a Sugar Cane Price Board, and declare the number of its members, and assign a name to the Board.

In every case the locality in which, and the particular mill or mills for which, the Board is to have jurisdiction shall be declared, and, where deemed necessary, the lands from which sugar cane is to be supplied to the mill or respective mills concerned may be specified.

\section{Constitution of Boards}

5. (I.) A Board shall consist of not less than four nor more than ten members and a chairman, as shall be declared in the Order in Council.

(2.) The Governor in Council may, on the recommendation of the Court, at any time remove any member of a Board, and, in accordance with this Act, appoint another member in his stead.

\section{Representatives}

(3.) One-half of the members of a Board shall be appointed as representatives of the owner or owners of the mill or mills, and one-half as representatives of cane suppliers. 
A member of the legal profession shall not be eligible to be a member of a Board.

(4.) Subject to this Act-

\section{Term of Office}

(a) Appointments as members of a Board shall be for one year only, but any member of a Board may, on the expiration of his term of office, be reappointed ;

(b) The chairman of a Board shall be deemed to be a member thereof:

Provided that when the Order in Council appointing a Board is rescinded the members of such Board shall forthwith cease to hold office.

\section{Election and Appointment of Board}

6. Within thirty days after a notification by the Registrar published in the Gazette of the creation by the Governor in Council of a Board, the owner or owners of the mill or mills and the cane suppliers shall elect their respective proportions of such Board.

The names of the persons so elected shall be filed in the office of the Registrar. If the Registrar is satisfied that such persons have been duly elected, he shall forward a certificate to that effect to the Minister. The Registrar shall refer to the Court any matter of dispute arising with respect to any such election, and the Court shall inquire into the same, and may order the Registrar to forward the prescribed certificate, or order a fresh election, or make any other order in the premises as it thinks proper ; and every such order shall be final and without appeal.

Upon receiving the aforesaid certificate, the Governor in Council, by notice published in the Gazette, shall appoint the persons named therein as representatives of the 
owner or owners of the mill or mills and representatives of cane suppliers to be members of such Board :

Provided that, if the owner or owners of the mill or mills or the cane suppliers fail to make such election within the time herein limited, the Governor in Council shall, by notice published in the Gazette, appoint persons as representatives of such owner or owners or cane suppliers failing to make such election.

\section{Vacancies, How Filled}

\%. If any vacancy occurs from any cause whatsoever in a Board, it shall be filled by election as aforesaid by the owner or owners of the mill or mills or cane suppliers whose representative has caused such vacancy, and the Governor in Council, by notice published in the Gazette, shall appoint the person so elected, or, in default of such election within fourteen days after the vacancy has arisen, he shall, by notice as aforesaid, of his own motion appoint some person as representative of the owner or owners or cane suppliers (as the case may require) for the unexpired portion of the term of office of the member who has vacated his seat.

\section{Appointment of Chairman}

8. (I.) The members of a Board shall, within fourteen days after their appointment, nominate in writing to the Registrar some person (not being one of such members) to be chairman of the Board.

The Registrar shall forward a certificate to the Minister stating the name of the person so nominated, whereupon such person shall be appointed by the Governor in Council to such office.

(2.) If the Registrar does not receive such nomination within fourteen days after the appointment of the said 
members, then the Governor in Council may, on the recommendation of the Court, appoint the chairman.

(3.) Any vacancy which occurs in the office of chairman shall be filled in like manner, and the person so appointed shall hold office only for the unexpired portion of the term of office of the person who has vacated office.

\section{Oath of Office}

8. Before the chairman or any member of a Board enters upon the duties of his office, he shall take and sign before a police magistrate an oath or affirmation that he will faithfully exercise and discharge the powers and duties of his office without fear of or favour to any person, and will not therein wilfully make any false or inaccurate statement. Every such oath or affirmation shall be filed in the office of the Registrar and recorded.

\section{Jurisdiction of Board}

10. A Board may, with respect to the locality and the mill or mills for which it has been created, make an award determining the price or prices to be paid and accepted by the owner or owners of the mill or mills and cane suppliers, respectively, for sugar cane sold and taken delivery of at the mill or mills concerned, and determining all matters relating to such supply of sugar cane and payment therefor.

\section{Exercise of Powers}

11. (I.) All powers of a Board may be exercised by a majority of the members thereof.

\section{Effect of Vacancy Caused by Resignation}

(2.) During any vacancy in a Board (other than in the office of chairman) caused by the resignation of a mem- 
ber, the continuing members may act as if no vacancy existed.

\section{Chairman May Administer Oaths, etc.}

12. The chairman may require any person (including a member) giving evidence before a Board to give his evidence on oath or affirmation, and for such purpose may administer an oath or take an affirmation.

For the purposes of compelling the attendance of persons to give evidence and the punishment of persons failing to attend when summoned or refusing to give evidence or produce documents or writings in their possession or power, the chairman shall have all the powers and authorities of a police magistrate sitting in a court of petty sessions.

\section{Award of Board}

13. The award of a Board shall be signed by the chairman and forwarded to the Registrar not later than the twenty-first day of April after the creation of the Board, or such later date as the Minister for any special reason may fix ; and the Registrar shall forthwith publish the same in the Gazette:

Provided that, if such award is not made and forwarded within the time herein prescribed, all the functions and jurisdiction of the Board so making default shall pass to and be exercised by the Court ; and the award of the Court when made shall have the effect of an award under this Act.

\section{Award to Remain in Force, for what Period}

14. Subject only to appeal to the Court, an award of a Board shall, from a date fixed by the Board, within the locality for which the Board has jurisdiction, take effect 
and have the force of law, and shall not be in any manner liable to be challenged or disputed, and shall be binding on all owners of sugar mills and cane suppliers in the locality to which the award applies, and shall remain in force for a period of twelve months, and after the expiration of that period shall continue in force, unless the Court otherwise orders, until a new award has been made.

There shall be an appeal to the Court against any award of a Board or any part thereof.

Such appeal may be brought by any owner or cane supplier bound by the award, and shall be commenced within fourteen days after the publication of the award in the Gazette.

The pendency of an appeal against an award or part thereof shall not, unless the Court otherwise orders, suspend or delay the operation of the award or any part thereof.

When the Order in Council creating a Board is rescinded, such rescission shall not affect the operation of any award made by such Board and then in force.

\section{Matters for Consideration of Board}

15. (I.) A Board, in making an award, shall take into consideration-

(a) The estimated quantity of sugar cane to be treated at the mill or mills concerned;

(b) The estimated sugar contents of the sugar cane;

(c) The efficiency of the mill or mills concerned;

(d) The selling price of sugar;

(e) Any other local conditions.

(2.) Such award shall, in addition to determining a minimum price, provide for increases in price on account of-

(a) Any increase in the quantity of sugar cane over the estimate: 
(b) Higher sugar contents in sugar cane;

(c) Increase in the selling price of sugar;

(d) Any other improvements in conditions.

(3.) Provided that sugar cane supplied by any cane supplier and containing over six per centum of procurable sugar shall not be refused to be taken delivery of by the owner of any mill.

\section{Breach of Award}

16. (I.) If any cane supplier bound by an award fails to carry out or abide by the terms of the award by refusing to supply his sugar cane to the mill in reasonable quantities as required, or disposes of his sugar cane to any mill to which the award does not apply. he shall be guilty of a breach of the award; and, in addition, to any penalty or punishment to which he may be liable, the owner of such mill may by his workmen enter in and upon the lands of the cane supplier and harvest his crop, paying to him the value of the same pursuant to the award after deducting the cost of cutting and harvesting and any other expenses incidental thereto.

(2.) If the owner of any mill bound by an award fails to carry out or abide by the terms of the award, he shall be guilty of a breach of the award.

(3.) Any person, company, corporation, firm, or association who or which commits a breach of an award shall be liable, if a person, to a penalty not exceeding fifty pounds, or, if a company, corporation, firm, or association, to a penalty not exceeding five hundred pounds; and, in addition, the Court by which the offender is convicted may, on motion or without motion, grant an order in the nature of an injunction to restrain such person, company, corporation, firm, or association from committing any further breach or non-observance of the award. If such person, company, corporation, firm, or association disobeys the said order, he shall, if a person, be liable to 
imprisonment with or without hard labour for any period not exceeding three months, or, if a company, corporation, firm, or association, it or they shall be liable to a penalty not exceeding fifty pounds for each and every day on which such disobedience takes place.

(4.) For the purposes of this section the making of an award shall be regarded as an agreement entered into between each cane supplier and owner, and nothing herein contained shall be construed to deprive any person or company bound by the award of any civil right or remedy against any other person or company so bound to compel observance of the award according to its tenour or in respect of any breach of agreement or otherwise.

\section{Return by Growers}

17. Not later than the thirty-first day of January in each year, every grower of cane shall furnish to the Minister a return showing-

(a) The area of land used by him in producing sugar cane and the value of the same;

(b) The value of buildings and plant exclusively used for growing sugar cane;

(c) The name of the mill or mills to which his sugarcane was supplied during the year then last past.

\section{Return by Owners of Mills}

18. Not later than the thirty-first day of January in each year, every owner of a mill shall furnish to the Minister a return showing-

(a) The value of plant, machinery, land, and buildings in connection with his mill;

(b) The value of all tramways and rolling-stock;

(c) The quantity of sugar cane crushed during the year then last past; 
(d) The percentage of extraction during the year then last past ;

(e) The persons from whom sugar cane was purchased during the year then last past.

\section{Powers of the Court}

19. For the purposes of this Act, the Court shall have and may exercise all the powers, authorities, and jurisdiction vested in it by "The Industrial Peace Act of I912."

\section{Intervention by the Crown}

20. The Crown may, where, in the opinion of the Minister, the public interests are or would be likely to be affected by the decision of the Court or the award of a Board, intervene in any proceedings before the Court or such Board, and make such representations as it thinks necessary in order to safeguard the public interests.

\section{Represcntation of Partics at Hearing}

21. On the hearing or determination of any matter arising under this Act, whether before a Board or the Court, any party interested shall be entitled to appear and be heard, whether personally or by his agent duly appointed in writing in that behalf.

\section{Award to be Posted Up}

22. There shall be kept printed, painted, or affixed in legible roman characters, in some conspicuous place at or near the entrance of every mill to which an award applies, in such a position as to be easily read by cane suppliers, a true copy of the award. 


\section{Proceedings for Offences Generally}

23. (I.) Proceedings in respect of offences against this Act shall be by complaint, and be heard and determined in a summary manner by a police magistrate:

Provided that appeals by way of quashing order or special case from the decision of such police magistrate shall lie to the Court and not to the Supreme Court.

(2.) The proceedings on such appeal shall, unless and until otherwise prescribed by Rules of Court, be regulated, mutatis mutandis, by "The Justices Acts, I886 to I909":

Provided that-

(i.) The Court on upholding a conviction may increase the penalty or punishment to such amount or term not exceeding that permitted by this Act, or may reduce such penalty or punishment as the Court deems proper;

(ii.) The Court may make such order concerning costs as it deems proper.

\section{Contracting Outside this Act Forbidden}

24. Any contract or agreement, whether entered into before or after the passing of this Act, between the owner of a mill and any cane supplier or grower of sugar cane, which, if it were valid, would have the effect of disentitling such cane supplier or grower of sugar cane to the benefit of an award or of any of the provisions of this Act, shall to that extent be absolutely void and inoperative.

\section{Evidence of Orders}

25. (I.) A copy of the Gazette containing an Order in Council purporting to be made by the Governor in Council under this Act shall be conclusive evidence of the making of such Order, and such Order shall not be liable to be challenged or disputed in any court whatever. 


\section{Evidence of Award}

(2.) An office copy of or copy of the Gazette containing an award, order, decision, or other act of the Court, purporting to be sealed with the seal of the Court, or an office copy of an award of a Board, certified to be true under the hand of the Registrar, or a copy of the Gazette containing the same, shall be received in all Courts and tribunals and before all persons as evidence of such award, order, decision, or other act without further proof ; and it shall not be necessary to prove any condition precedent entitling the Court or Board to make the decision, order, or award.

\section{Regulations}

26. (I.) The Governor in Council may from time to time make regulations providing for all or any purposes, whether general or to meet particular cases, that may be convenient for the administration of this Act or that may be necessary or expedient to carry out the objects and purposes of this Act, and, where there may be in this Act no provision or no sufficient provision in respect of any matter or thing necessary or expedient to give effect to this Act, providing for and supplying such omission or insufficiency.

(2.) The regulations may fix a penalty, not exceeding in any case ten pounds, for any breach thereof.

(3.) All such regulations shall be published in the Gazette; and thereupon, subject to subsection four hereof, shall be of the same effect as if they were contained in this Act.

Such regulations shall be laid before both Houses of Parliament within fourteen days after such publication, if Parliament is in session, and, if not, then within fourteen days after the commencement of the next session.

(4.) If either House of Parliament passes a resolution disallowing any such regulation, of which resolution notice has been given at any time within fourteen sitting days of 
such House after such regulation has been laid before it, such regulation shall thereupon cease to have effect, but without prejudice to the validity of anything done in the meantime.

\section{Power to Amend or Rescind Orders in Council}

27. (I.) The Governor in Council may, by another Order in Council published in the Gazette, amend or rescind any Order in Council made under this Act.

\section{Misnomer, etc., not to Prejudice}

(2.) No misnomer or inaccurate description or omission in or from any Order in Council made under this Act shall in anywise prevent or abridge the operation of this Act with respect to the subject-matter, provided the same is designated so as to be understood.

\section{Informalities}

(3.) No Order in Council purporting to be made under this Act, and being within the powers conferred on the Governor in Council, shall be deemed invalid on account of any non-compliance with any of the matters required by this Act as preliminary to the same. 


\section{BY THE SAME AUTHOR}

\section{THE UNDERLYING PRINCIPLES OF}

MODERN LEGISLATION. By W. Jethro Browx, LL.D., Litt.D., Professor of Law in the University of Adelaide. New and cheaper edition. Demy 8vo. 6s. net.

"This expression of a philosophical personalit5, the opus nagnum of a thinker to whom a collection of statutes is a blurred, ret decipherable record of the undying warfare between ideas and ideals.... The author in his latest manifestations may be defined as the Eucken of Political Science."-The Morning Post.

"So interesting, so persuasire, and so easy to understand that many will be apt to overlook the importance of this work as a real contribution to political thonght. . . . The author urges that every candidate for a university degree ought to study seriously the theory of legis. lation. If this were to be done, we shonld find it difficult to imagine a more useful text-book than the volume now under consideration. . . . Opposing theories are expounded clearly and with great impartiality; the attempts to carry out these theories are examined, their successes and failures, more particularly what mas be called their bye-products." - The Cambridge Review.

"Mr. Brown is quite as much a humanist as a lawyer. His style is tonched with a fine emotion. . . He brings a clear, able, philosophic mind to his eramination of contemporary thought."-Pall Mall Gaztte.

\section{THE AUSTINIAN THEORY OF LAW.}

Being an Edition of Lectures I, V, and VI of Austin's "Jurisprudence," and of Austin's "Essay on the Uses of the Study of Jurisprudence." With Critical Notes and Excursus by W. Jethro Brown, LL.D., Litt.D., of the Middle Temple, Barrister-at-Law. Demy Sro. 10s. 6d. net.

"We are praising this book not for the sake of Austin, but for that of Prof. Brown. His numerous notes and excursus furnish exactly what the student requires."-Athenaum. 


\section{SOCIAL WORK IN LONDON, 1869-1912.}

A History of the Charity Organisation Society. By Hrlen Bosanquet, LL.D. With Portrait of Mr. C. S.

Loch. Demy 8vo. 8s. net.

"Mrs. Busanquet's history is a contribution to sociological literature of considerable and permanent value both as a record of facts and as an exposition of principles. The origin, development, and work of the Charity Organisation Society form a chapter-not a very large, but a distinct and significant one-in the social history of onr time, and future students will be indebted to Mrs. Bosanquet for her account of Society."-The Times.

\section{SOCIAL REFORM : As related to Realities}

and Delusions. An examination of the increase and distribution of wealth from 1801 to 1910 . By W. H. MaLlock, Author of "A Critical Examination of Socialism," etc. Crown 8vo. 6s. net.

\section{THE DANGERS OF DEMOCRACY.}

Studies in the Economic Questions of the day. By the late Thomas Mackay, Author of "A History of the Poor Law," etc. Edited with an Introduction by Sir Arthur Clay, Bart., Author of "Syndicalism and Labour," etc. Crown 8vo. 6s, net.

"The book contains exceedingly valuable criticism, clothed in a pleasing prose style which places analysis and reasoning in its most illuminating position. It provides a powerful corrective for those who accept contemporary ideas without individual thought."-Liverpool Daily Courier.

\section{LIFE AND HUMAN NATURE. By Sir}

Bampfylde Fulder, K.C.S.I., C.I.E., Author of "Studies of Indian Life and Sentiment." Demy 8vo. 9s. net.

This work is an attempt to construct a natural history-or scienceof human nature by tracing behaviour of mind or body to impulses which actuate, more or less definitely, all living creatures, and may be regarded as Life's manifestations of itself. It is, moreover, a review of man's material, social, economic, and political development, and illustrates the effects of these impulses, as modified by race and environment, and influenced by the will and the habits of mind and body which are the foundations of culture. 


\section{SEA LAW AND SEA POWER. As they}

would be affected by Recent Proposals. By T. Gibson Bowles, Author of "The Declaration of Paris of 1856." Demy 8vo. 7s. 6d, net.

"Any careful and intelligent discussion of the law of the sea is to be welcomerl. Mr. Gibson Bowles has long studied the subject; and this book, revealing in every page profound conviction, is the concentrated spirit of many speeches, letters, and discussions dealing with the same problems. The earnestness with which he pleads his cause would merit and command a hearing."-Times Literary Supplement.

THE KING'S CUSTOMS. An account of

Maritime Revenue and Contraband Traffic in England, Scotland, and Ireland. By Henrey Atton and Henry Hurst Hollaxd. Vol. I - From the Earliest Times to the Year 1800. Vol. II-From 1800 to 1855 . With Illustrations. Demy 8vo. 10s. 6d. net each.

"We can scareely conceive a more difficult task than writing an interesting history of a Public Department. Yet the book before us is both interesting and instructive. The authors have produced an exceedingly useful work, and have shown the same judgment in selection as in the case of the first volume."-Civil Service Gazetto.

\section{Works by Sir Henry S. Maine.}

ANCIENT LAW. Its connection with the Early History of Society, and its relation to Modern Ideas. With Introduction and Notes by Sir Frederick Pollock, Bart. Demy 8vo. 5s, net.

ANCIEN'T LAW. Demy 8vo. 2s. 6d. net. INTRODUCTION AND NOTES TO MIAINE'S ANCIENT LAW. By Sir FrEDERICK Pollock, Bart. Demy 8vo. 2s. 6d. net.

VILLAGE COMMUNITIES IN THE EAST AND WEST. Six Lectures delivered at Oxford. Demy 8vo. 9s.

LECTURE ON THE EARLY HISTORY OF INSTITUTIONS. Demy 8vo. 9s.

DISSERTATIONS ON EARLY LAW AND CUSTOM. Demy 8vo. 9s.

POPULAR GOVERNMEN'T. Four Essays. Cheap Edition. Large Crown 8vo. 2s. 6d. net.

INTERNATIONAL LAW. The Whewell Lectures, delivered at Cambridge in 1887. Demy 8vo. 7.. $6 \mathrm{~d}$. 


\section{THE NEW DEMOCRACY AND THE}

CONSTITUTION. By Williay Sharp McKecinie, M.A., LL.B., D.Phil., Lecturer on Constitutional Law and History in Glasgow University. Demy 8vo. 6s. net.

"It is not too much to say that no more masterly exposition of the real meaning of the democratic theory of Government, as applied more especially to our own institutions to-day, has ever been written. No earnest well-wisher of his country, whether a democrat or not, can refuse to study it."-Globe.

\section{INDUS'IRIAL WARFARE: The Aims} and Claims of Capital and Labour. By Charles Watney and James A. Little. Crown 8vo. 6s. net.

"Here is a book which ought to be at erery journalist's elbow and on every legislator's bookshelf. It rould be too much to hope that it will be on the shelf of every reader of newspapers. Yet without some such key as this the industrial problem must continue to defeat the understanding of the busy citizen, whom the newspapers often credit with a full knowledge of labour personalities and aims."-Observer.

\section{WHERE SOCIALISM FAILED: An} Actual Experiment. By Stewart Grainame. Crown 8vo. With Illustrations and Map. 6s. net.

"Tells the story of an item in the long list of futile attempts to establish Socialist communities. 'New Australia' collapsed from mismanagement, extravagance, indolence, and heathenism, providing the world with an object-lesson of the hopeless fatility of Socialism. The book is one of the best answers to Red Flag theories that have yet appeared,"-Daily Express.

\section{'THE CULT OF INCOMPETENCE. By}

Emile Faguet. Translated from the French by Miss Beatrice Barstow. With an Introduction by Thomas Mackay. Crown 8vo. 5s, net.

"If readers of this volume will take the trouble to annotate their copies with a record of the relevant incidents which meet them every day of their lives, they cannot fail to acknowledge how terribly inevit. able is the rise of incompetence to political power. M. Faguet's book is terse, witty, and interesting, and should be widely read in this very capable English rendering."-Daily Telegraph. 
THE BASIS OF SOCIAL RELATIONS.

A Study in Ethnic Psychology. By Daxiel G. Bristox. Edited by Liringston Farrasd. Demy 8vo. 8s. net.

\section{THE PRINCIPIES AND METHODS OF TAXation. By G. Armitage Smith, M.A., Principal of Birkbeck College. Crown 8ro. Cheap Edition. 2s. 6 d. net.}

The object of this work is to present in a concise and simple form an account of the British system of taxation and the principles on which it is based, together with some of the leading historical facts in its evolution.

"A treatise as useful as it is modest, which discusses in a broad and lucid way the principles and history and difficulties of taxation." -St. James's Gasette.

\section{ELEMENTS OF POLITICAL ECONOMY. By Jayes Bonar, M.A., LL.D. 2nd Impression. $4 \mathrm{~s} .6 \mathrm{~d}$.}

"It is pleasant to find a modern book on economics written in simple English unencumbered by those cabalistic phrases in which the veiled prophets of sociology delight."-Morming Post.

\section{CRIMINAL RESPONSIBILITY AND} SOCIAL CONSTRAINT. By Ray Maddixg McCoxnell, $\mathrm{Ph}$. D., late Instructor in Social Ethics, Harvard University. Demy 8vo. is. 6d, net.

"Dr. McConnell's book is valuable for the excellent way in which the pro and contra argaments relating to the received theories of punishment are marshalled."-Glasgorc Herald.

\section{THE NAVY LEAGUE ANNUAL.}

Founded and Edited by Alax H. Burgorse, M.P. With Illustrations. Demy 8ro. 5s. net.

"One of the most valuable pieces of work done under the anspices of the Nary League in recent years has been the publication of this Annual. . . The British pablic ores mach to its founder and editor, Mr. Alan Burgorne, M.P., for making accessible-at very small cost, and in a form which can be geverally understood-a great mass of information respecting the war fleets of the world, their organization, programmes of cunstrnction, and expenditure.

Already the Annual has established itself a one of the best books of reference on naval subjects."-Spectator. 


\section{COLLECTIVISM : A Study of some of the}

Leading Social Questions of the Day. By Paul LeroxBeaulieu, Member of the Institute, and Professor of the College of France. Abridged and Translated. By Sir Arthur Clay, Bart. Demy 8vo. 10s. 6d. net.

"It is a scarching exposure of the shallowness and sophistry of the leading Socialistic writers of our time, and could it only be plainly made known to the crowds who unthinkingly believe and applaud the Bocialistic agitators in onr streets, it would serve a still more useful purpose. ... Many difficulties which the Socialists have not detected are explained with much force and lucidity in M. Beanlieu's book which it is to be hoped will be carefully read by all who have it in their power to influence the working classes of this country." Forkshire Post.

\section{LOCAL AND CENTRAL GOVERNMENT:}

A Comparative Study of England, France, Prussia, and the United States. By Percr Ashlex, M.A., Lincoln College, Oxford; Lecturer at the London School of Economics and Political Science in the University of London; Author of "Modern Tariff Histors." Demy 8vo. 10s. $6 \mathrm{~d}$. net.

\section{THE MANUFAC'TURE OF PAUPERS :}

A Protest and a Policy. By Sir Arthur Chax, Bart., Sir William Chance, Bart., Sir Edward Brabrook, W. A Bailward, Miss $\mathrm{K}$. V. Bannatyne, Thomas Mackax, Colonel E. Montefiore, and Mrs. E. T. OGilvx. With an Introduction by J. ST. LoE Stracher. Large Crown 8vo. 2s. 6d. net.

"These papers form a strong and emphatic condemnation of the - dole' system of government, which is becoming more and more characteristic of modern England, and which is viewed with so much concern by all those who value manly independence and individual intelligence. The book should be carefully studied by those sentimental but unwise people who continually cry aloud for the State to do this or that, without pausing to recollect that every new step in that direction is helping to destroy all that has made England in the past. The articles on the feeding of school children are especially vigorous."-Sheffield Daily Telegraph.

\section{MUNICIPAL OWNERSHIP. By Major}

Leonard Darwin, Author of "Municipal Trade," and "Bimetallism." Crown 8vo. 2s.6d. net.

Four Lectures delivered at Harvard University, discussing in a popular manner the advantages and disadvantages of Municipal Ownership, a Municipal Trade is called in the United States. 
a

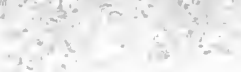

$2=$ 



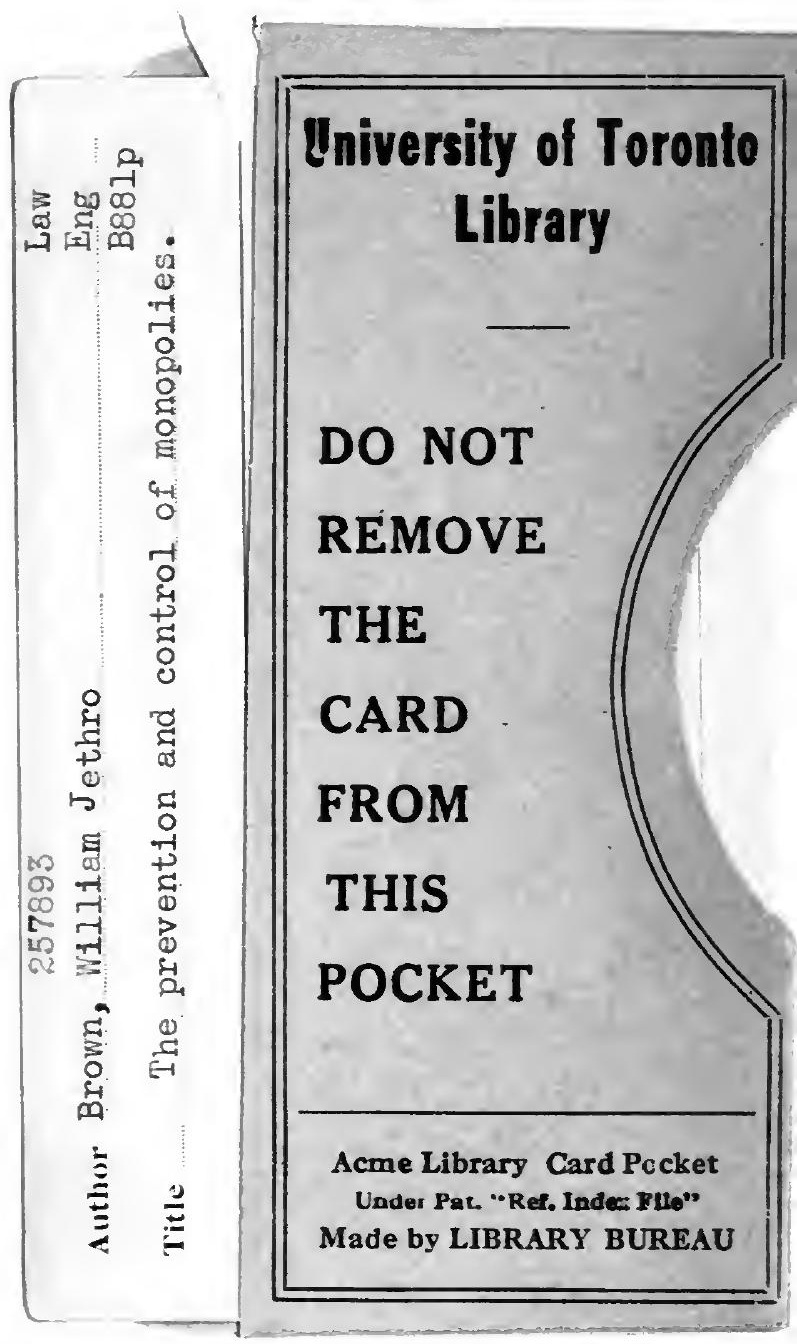


